NASA TM. 82650

DOE/NASA/20485-10

NASA TM-82650

\title{
Design Description of the Schuchuli Village Photovoltaic Power System
}

Anthony F. Ratajczak, Richard W. Vasicek, and Richard DeLombard

National Aeronautics and Space Administration

Lewis Research Center

May 1981

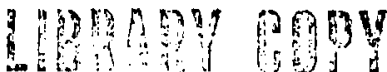

AUG 131981

EAVGLEY HESEARGH CENTES

LIERIRY', NASA

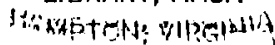

Prepared for

U.S. DEPARTMENT OF ENERGY

Conservation and Renewable Energy

Division of Solar Thermal Energy Systems 


\section{MOTICE}

This report was prepared to document work sponsored by the United States Government. Neither the United States nor its agent, the United States Department of Energy. nor any Federal employees, nor any of their contractors, subcontractors or their employees, makes any warranty. express or implied. or assumes any legal liability or responsibility for the accuracy, completeness, or usefulness of any information. apparatus. product or process disclosed, or represents that its use would not infringe privately owned rights

Trade names or manufacturer's names are used in this report for identification only. This usage does not constitute an official endorsement, either expressed or implied, by the National Aeronautics and Space Administration. 
DOE/NASA/20485-10

NASA TM-82650

\section{Design Description of the Schuchuli Village Photovoltaic Power System}

Anthony F. Ratajczak, Richard W. Vasicek, and Richard DeLombard

National Aeronautics and Space Administration

Lewis Research Center

Cleveland, Ohio 44135

May 1981

Work performed for

U.S. DEPARTMENT OF ENERGY

Conservation and Renewable Energy

Division of Solar Thermal Energy Systems

Washington, D.C. 20545

Under Interagency Agreement DE-Al01-79ET20485 



\section{CONTENTS}

Page

ACRONYMS AND ABBREVIATIONS $\quad$ iv

SUMMARY

INTRODUCTION $2 \quad 2$

$\begin{array}{ll}\text { SYSTEM DESCRIPTION } & 7\end{array}$

$\begin{array}{ll}\text { SYSTEM DESIGN } & 25\end{array}$

Load and Load Profiles $\quad 25$

Photovoltaic (PV) Array and Battery Sizing $\quad 42$

Mechanical Designs $\quad 52$

Electrical Designs $\quad 54$

$\begin{array}{ll}\text { Safety } & 69\end{array}$

COMMENTS ON SYSTEM OPERATION $\quad 70$

$\begin{array}{ll}\text { CONCLUDING REMARKS } & 70\end{array}$

APPENDIXES

A. DESIGN DRAWINGS--NASA LERC DRAWING NOS. CF 56375

THROUGH CF 56382

B. MANUFACTURERS AND EQUIPMENT

89 


\title{
ACRONYMS AND ABBREVIATIONS
}

\author{
DAT-3 automatic data recorder \\ DOD depth-of-discharge \\ DOE Department of Energy \\ DSB Domestic Services Building \\ EEB Electrical Equipment Building \\ EWS electronic weather station \\ I/C . instrumentation and control \\ LeRC Lewis Research Center \\ NASA National Aeronautics and Space Administration \\ PCCIA power collection, control and instrument assembly \\ PTUA Papago Tribal Utility Authority \\ PV photovoltaic \\ SOC state-of-charge \\ T\&A Tests and Applications Project
}




\section{SUMMARY}

This report describes the engineering design of a stand-alone photovoltaic (PV) power system for the village of Schuchuli (Gunsight), Arizona, on the Papago Indian Reservation. This experimental solar power system project was funded by the Department of Energy and implemented by the National Aeronautics and Space Administration, Lewis Research Center, together with the United States Department of Health and Human Services, Public Health Service, Indian Health Service, Office of Research and Development, Office of Environmental Health, and the Papago Tribe of Arizona. The purpose of this experiment was to demonstrate that a stand-alone photovoltaic power system could provide dependable power for basic human needs in a remote village environment.

The power system was designed as a limited energy, all $120-\mathrm{V}$ (d.c.) system to which loads cannot be arbitrarily added. The system consists of a $3.5-\mathrm{kW}$ (peak) PV array, 2380 ampere-hours of battery storage, an Electrical Equipment Building, a $120-\mathrm{V}$ (d.c.) electrical distribution network, and equipment and automatic controls to provide control power for pumping water into an existing water system; operating 15 refrigerators, a clothes washing machine, and a sewing machine in the Domestic Services Building; and lights for each of the homes and communal buildings. In addition, a solar hot water heater was provided to supply hot water for the washing machine and communal laundry. The system employs automatic control systems which provide voltage control by limiting the number of PV strings supplying power during system operation and battery charging, and load management for operating high priority loads at the expense of low priority loads as the main battery becomes depleted.

The engineering design of this system is presented in this report and includes loads profiles and loads descriptions; an explanation of the PV array and battery sizing methodology; descriptions of the mechanical designs; electrical designs and descriptions of the array, battery, controls, instrumentation and distribution system; and a discussion of safety features. The system was dedicated and began operation on December 16, 1978. The operational history and data are not contained in this report. 


\section{INTRODUCTION}

The Department of Energy (DOE) is pursuing a National Photovoltaic Program aimed at developing cost effective photovoltaic (PV) power systems capable of providing a significant amount of the Nation's energy requirements with solar energy by the year 2000. In 1978, this program was divided into several projects, one of which is the Stand-Alone Applications Project which is being managed for DOE by the National Aeronautics and Space Administration Lewis Research Center (NASA LeRC).

The Stand-Alone Applications Project is intended to introduce PV power systems by several means to a wide range of potential users wit: near-term applications tc accelerate their entry into the commercial market. Applications which indicate near-term cost effectiveness, technical feasibility, solar cell promotional value, and/or substantial use multiplication are considered for appropriate support. Based on these objectives, a photovoltaic power system for the village of Schuchuli (Gunsight), Arizona, on the Papago Indian Reservation was selected for implementation.

Participating in tis joint experiment are: NASA Lewis Research Center; the United States Department of Health and Human Services, Public Health Service (PHS), Indian Health Service, Office of Research and Development, Office of Environmental Healti:; and the Papago Tribe of Arizona (PTA).

The Village of Schuchuli, with a population of approximately 96 people, is located in the far western part of the Papago Indian Reservatior about 120 miles west of Tucson, Arizona, on State Highway 86 (see map, Figure 1). At the time the system design was developed, the village had 15 homes*--some "traditional" and some modern ranch style--a church, feast house, miscellaneous small structures and sheds, a large corral, and a water supply system. Prior to the installation of the PV power system, the village had no electrical service. The nearest available Papago Tribal Utility Authority utility line was approximately 17 miles from the village. The village water supply system consisted of two wells, one drilled (new well) and the other dug (old well, equipped with a gasoline powered pump used as standby); a positive displacement pump at the new well powered by a 7-hp. single cylinder, manual start diesel engine; 4- and 2-in. water distribution lines; and a 11,000-galloncapacity steel water storage tank. This system served the villagers and their livestock. (See photograph of village, Figure 2.).

The new village PV power system is a limited energy, all $120-V$ (d.c.) system to which loads cannot be arbitrarily added. This stand-alone

\footnotetext{
* Three homes have since been added.
} 
utility system consists of a $3.5-\mathrm{kW}$ (peak) PV array, electrical storage batteries, an Electrical Equipment Building (EEB), a 120-V(d.c.) electrical distribution network, and equipment and automatic controls to provide central power for: pumping water for the existing water system; operating 15 refrigerators, a clothes washing machine, and a sewing machine in the Domestic Services Building (DSB); a solar hot water heater for the laundry; and lights in each of the homes and communal buildings (see block diagram of system, Figure 3 and Site and Location Plan, Appendix A, Drawing No. CF 56376). The selection of the specific appliances and services was made jointly among the participants and included inputs from the villagers. This system employs an automatic control system which provides voltage control and load management for operating high priority loads (refrigerator/freezers) at the expense of low priority loads (washing and sewing machines) as the main battery charge becomes depleted. Operation of the low priority loads is resumed as the main battery becomes recharged. The control system also provides voltage control during operation and battery charging by limiting the number of PV strings supplying power to the system. (Manufacturer equipment is listed in Appendix B.)

In general, NASA LeRC provided the PV power system, pump motor, appliances, solar hot water heater, and light fixtures together with construction management, system checkout, and instruction for operating personnel. The PHS provided for the mechanical hook-up of the motor to the pump, pump fence, and sanitary drainage for the EEB and DSB. The PTA provided the DSB (except electrical wiring) and interior electrical wiring of village homes, feast house, and church. Construction was done by the Papago Construction Company. The pole line power distribution system was provided and installed by the Papago Tribal Utility Authority. The installed cost of this system is approximately $\$ 330,000$.

The experimental phase of the project is scheduled for a 3-year period (approximately January 1979 to January 1982) following the installation and checkout of the system. During this period, the operation, maintenance, troubleshooting, and repairs will be shared by the PTA, PHS, and NASA LeRC. Daily, weekly, and monthly records of data and inspections are taken and analyzed. NASA LeRC performs site inspections at least twice a year. At the conclusion of the 3-year experimental period, the disposal of government property will be made based on negotiations with the PTA. 


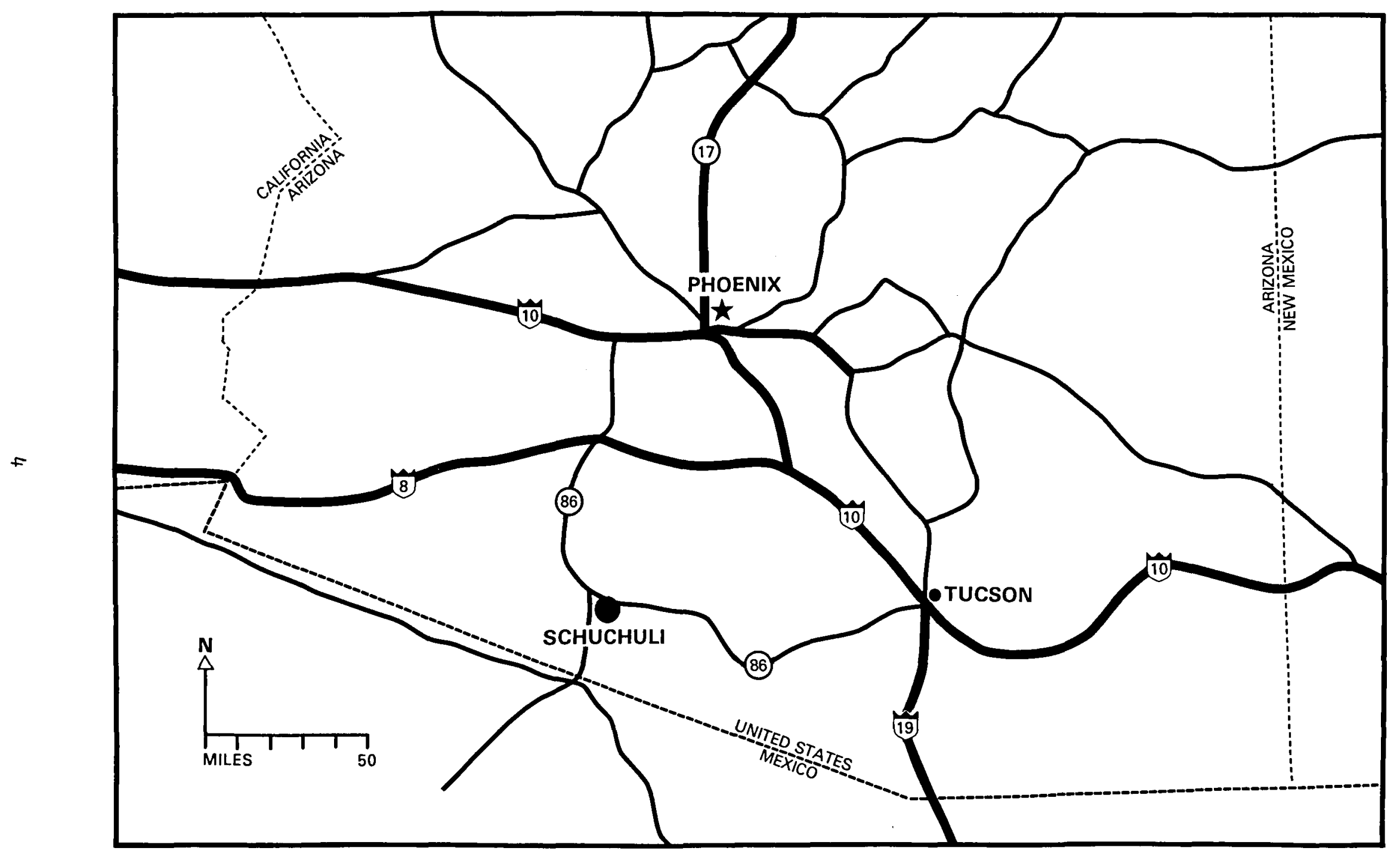

Figure 1. Location of Project 


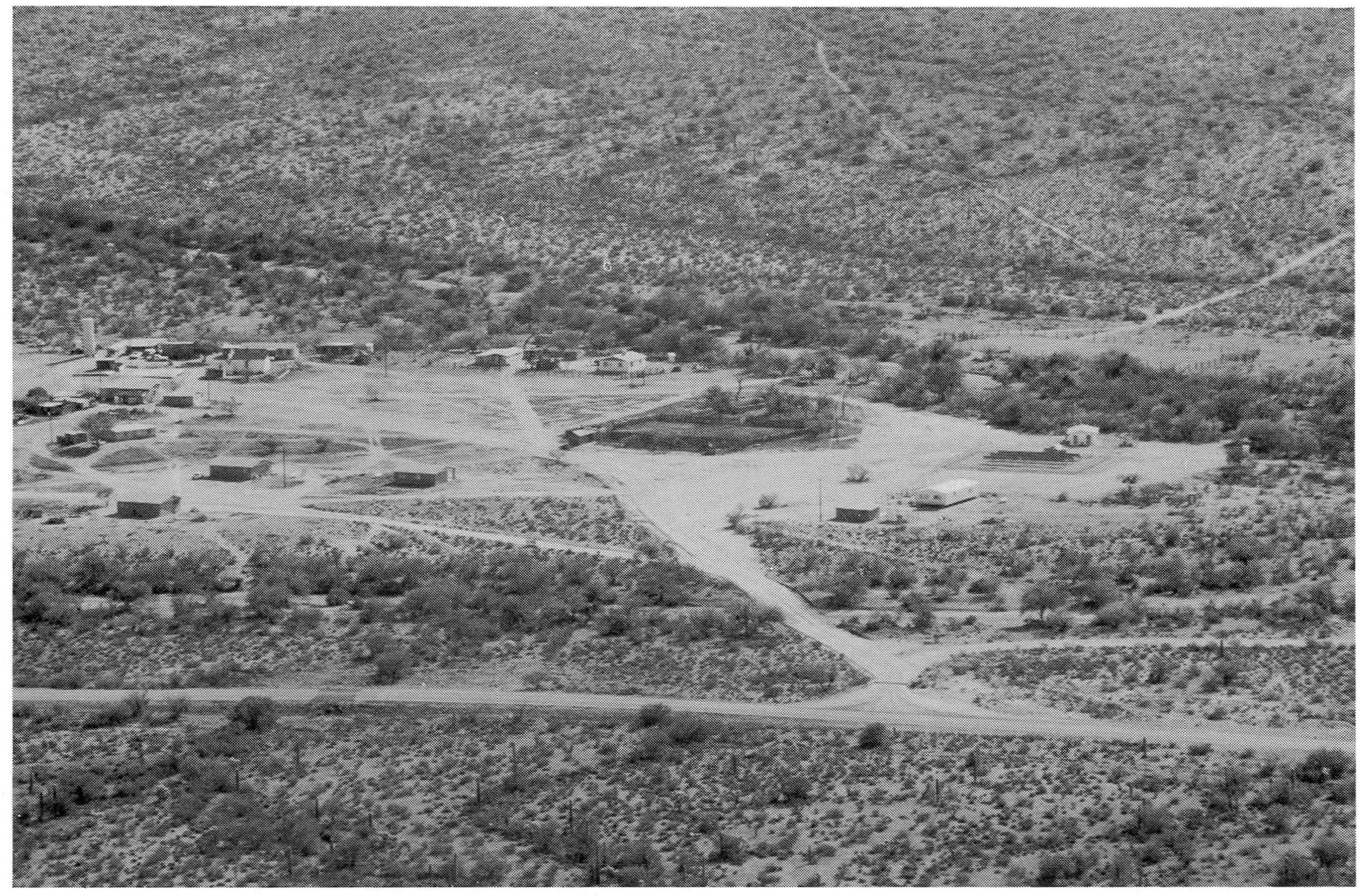

Figure 2. Schuchuli Village (looking southeasterly) 


\begin{tabular}{|l|}
\hline \multicolumn{2}{|c|}{ PHOTOVOLTAIC ARRAY } \\
\hline SOLAR CELL PANELS - $3.5 \mathrm{~kW}$ peak \\
- MODULES (192) \\
- WIRING HARNESSES \\
- FRAMES (24) \\
- SUPPORT STRUCTURES \\
FENCE \\
ELECTRICAL GROUND MAT TO \\
FENCE AND PANELS \\
CABLING AND CONDUIT \\
METEOROLOGICAL SENSORS \\
\hline
\end{tabular}

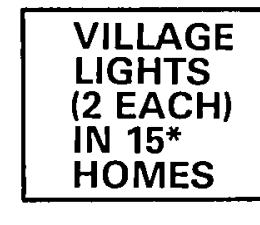
STORAGE

TANK

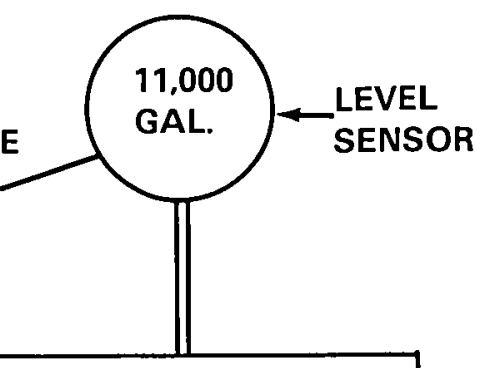

DOMESTIC SERVICES BUILDING

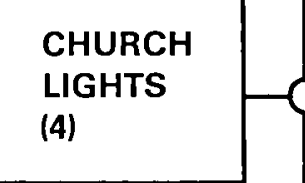

15 REFRIGERATOR/FREEZERS SOLAR HOT WATER HEATER WASHING MACHINE

SEWING MACHINE

SANITARY TUBS

LIGHTS (2)

\section{HOUSE}

LIGHTS

BATTERIES

2380 AMP.HR

RACKS

TURBINE

DISTRIBUTION,

CKT BREAKERS

AUTO DATA

SYSTEM

LIGHTS (2)
EYE WASH \&

SHOWER
(7)

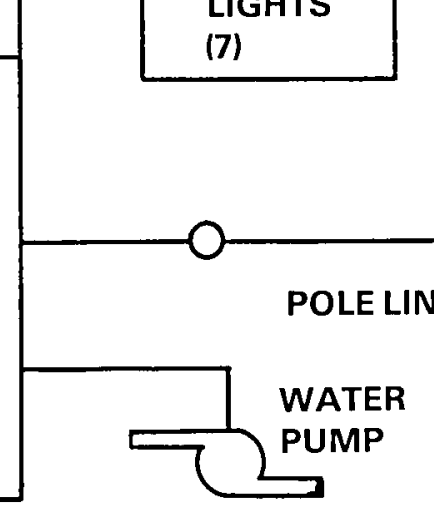

*15 homes were in the original system design and construction. Subsequently, 3 additional homes were included in the system.

Figure 3. Block Diagram of Schuchuli Village Power System 


\section{SYSTEM DESCRIPTION}

The photovoltaic power system is a small, limited energy, selfcontained, all $120-\mathrm{V}$ (d.c.) electrical utility system which consists of a 24panel PV array, commercially available lead-calcium storage batteries, instrumentation and controls housed in an Electrical Equipment Building (EEB), $120-\mathrm{V}$ (d.c.) electrical distribution network and the various motors, lights, instruments, and controls that constitute the electrical loads. The system provides the electrical power and automatic controls for the existing village water supply system; fluorescent lights in the village buildings and homes; and 15 refrigerators (one for each family in the village), a washing machine, and a sewing machine in the Domestic Services Building (DSB). A solar thermal hot water heater is located on the roof of the DSB and supplies hot water for the laundry. The freeze protection heater in this unit is powered from the PV system. The sensors and PV array for a selfcontained electronic weather station (EWS) are located within the fenced array area with its battery and recording equipment located in the EEB.

The 3.5-kW (peak) PV array consists of three rows of eight panels each mounted to steel frames and uprights set in concrete piers enclosed within a 100 - by $76-\mathrm{ft}$ area secured by an individual type chain link fence (Figure 4). Each PV panel contains eight Solarex $9200 \mathrm{~J}$ modules connected in series to form a nominal $120-\mathrm{V}$ string. The panels have three tilt angle positions and are changed four times a year to $48^{\circ}, 35^{\circ}, 11^{\circ}$, and $35^{\circ}$ from the horizontal to seasonally maximize the array output. The rows are stepped in elevation on the uprights to reduce the spacing between rows while eliminating low sun angle shadowing. The array panels and supporting structure are designed for $100-\mathrm{mph}$ winds.

The electrical storage system is installed in a vented room in the EEB and consists of the $120-\mathrm{V}$ main battery and the $12-\mathrm{V}$ instrumentation and control (I/C) battery. The $120-\mathrm{V}$ main battery consists of 52 cells rated at 2380 ampere-hours and four "pilot" cells (Figures 5 and 6) which are used in conjunction with the load management system discussed in detail in a following paragraph. Together, the pilot cells represent approximately 50, 10, 10, and 10 percent capacity increments of the main battery. The first or $" 50$ percent" pilot cell is rated at 1055 ampere-hours and the other three or "10 percent" pilot cells are rated at 310 ampere-hours each. During normal charging battery operation, i.e., when all pilot cells are fully charged, the four pilot cells are connected in parallel and together constitute the 53rd cell of the main battery (Figure 7). The 12-V I/C battery consists of 6 cells rated at 1055 ampere-hours each and is kept charged from the main battery through a d.c./d.c. converter.

The instrument and control system provides for the sequential disconnecting of individual PV array strings during battery charging, for sequential 
load shedding during progressive battery depletion, and for the automatic operation of the water pump. Figure 8 is an overall view of he instrument and control panel. The Power Collection, Control, and Instrumentation Assembly (PCCIA) collects all power from the array and the main battery. It contains most of the controls for the array string switching, load management, and safety system. It also contains most of the instrumentation. Specifically, it contains the drum programmer; 17 ammeters, 2 of which are meter relays; 17 ampere-hour meters; 8 volt meters, 5 of which are meter relays; 8 run-time meters; blocking diodes for each array string; fuse disconnects for each array string; control relays; and a d.c./d.c. converter. It also contains a switchable panel meter to read and display temperatures for one main battery cell, one array panel, a refrigerator compartment, and the pump motor. The meter relay is a combination of an analog meter and low power relays which are used to actuate power relays for various system control functions. The analog indicator on the meter has the same function as a needle on a standard meter, showing the voltage of the circuit. The meter also contains two adjustable set point needles. When the analog needle moves past an upper or lower set point, the internal relay contacts are transferred. It should be noted that the instrument panel contains instrumentation for complete input-output measurements to facilitate a full understanding and analysis of this experimental system. If this system were to be replicated as a strictly operational system, most, if not all, of these instruments might be omitted.

Data from the I/C system are taken in two ways: (1) by daily observation of meters recorded by hand on prepared data sheets (Figure 9) and (2) automatic recording at hourly intervals by the DAT-3 (Figure 10). The parameters read by the DAT-3 are shown in Figure 11. The cassette tapes and the data sheets are sent to NASA LeRC for data reduction.

System voltage regulation and battery charge control are accomplished by PV array string switching. Each of the 24 series strings in the array is connected to the main bus through a solid-state relay. A controller senses system voltage and commands a programmable drum relay to disconnect sequentially (open circuit) individual series strings to keep the system voltage at or below the maximum battery charge voltage $\left(V_{H I}=130 \mathrm{~V}\right)$ and to reconnect these strings sequentially when the system voltage falls to a predetermined lower level $\left(\mathrm{V}_{\mathrm{LO}}=125 \mathrm{~V}\right)$.

Because of uncertainties regarding actual power usage, a load management system was included in the design to protect the battery from excessive discharge and to maintain service to critical loads at the expense of less critical loads. This load management system uses the indication of main battery depth-of-discharge (DOD) levels to trigger sequential load shedding. Main battery depth-of-discharge is determined by sensing end-of-discharge voltage $(1.95 \mathrm{~V})$ of each of the four pilot cells which, during discharge, are individually connected in series with the main battery cells starting with the No. 1 or "50 percent" pilot cell. When the No. 1 or 50 percent pilot cell becomes discharged, the washing and sewing machines are disconnected, the 50 percent pilot cell is disconnected, and the No. 2 pilot cell is connected in series with the main battery. If the main battery is further discharged, the sequence continues such that at approximately 60 percent DOD, the No. 
2 pilot cell reaches its discharge voltage and the village lights are disconnected (except in the DSB and EEB) and the third pilot cell connected; at approximately 70 percent DOD, the water pump and the third pilot cell are disconnected and the fourth pilot cell connected; and at approximately 80 percent DOD, the refrigerators are disconnected. The lights in the DSB and the 300-W freeze protection heater in the Solarhart water heater are disconnected with the refrigerators. During recharge, the pilot cells and the associated loads are reconnected in the reverse sequence. "Full discharge" operation and subsequent time standing so discharged will affect the lifetime of the pilot cells but provide the desired protection for the other 52 cells of the main battery. As previously described, during normal charging operation (i.e., when the main battery and the pilot cells are fully charged), all four pilot cells are connected in parallel and together act as an additional series cell. Pilot cell sequencing and load shedding are accomplished by the programmable drum relay. It should be noted that the lights in the EEB are not included in the load shedding sequence.

System over- and under-voltage protection is also provided as a backup to the system voltage control and load management controls. If the system voltage exceeds a maximum allowable value $(135 \mathrm{~V})$, the entire PV array is disconnected. If the system voltage drops below $95 \mathrm{~V}$, all loads are disconnected. Alarm lights and an audible alarm are provided to indicate these conditions. Also, a manual emergency switch disconnects array, batteries, and loads.

The basic water supply system was in place and functional using a 7-hp, single cylinder, diesel engine to power the pump (Table 1). Control was accomplished by observation of the supply tank level target; when the water level was low, an appropriate amount of diesel fuel was put into the engine tank, and the diesel engine started to power the pump. Experience with the system established the amount of fuel to be used so that the fuel was expended and the engine stopped when the tank level was restored. The new system replaced the diesel engine with a 2-hp, 120-V(d.c.) permanent magnet motor and automatic controls employing water level sensors at the storage tank (Figure 12).

The pump motor operation is controlled automatically by water level sensors in the water storage tank and a PV array current sensor. During normal operation, the pump motor operates only in the daytime (i.e., when the array is generating power) and starts the pumping when the tank level is approximately $1.5 \mathrm{ft}$ below "full." As long as the pump load has not been shed, a low level sensor starts the pump when tank water level falls below half the tank capacity regardless of array output. Whenever the motor is started in the automatic mode, the pump motor will operate until the water level is restored to the full level in the tank, or the battery becomes discharged beyond 70 percent DOD and sheds the pump load as described above. The pump area is protected by a commercial grade chain link fence. The fence gate to the area is kept locked as a safety measure as the automatic starting of the pump could cause severe injury. A manual on-off switch is located at the pump to provide additional protection for personnel doing maintenance work. 
There are 15 individual refrigerator/freezers located in the DSB. Originally, the design was for one large refrigerator and one large freezer to be located in the DSB; therefore, the control system load management, Drum Programmer, etc., were designed for local control in the DSB. Well after the design was completed and parts of the control system developed, the villagers, through the village chairman, indicated their desire for the individual units. To stay with the existing control system design of load management, it was agreed that these units would remain in the DSB to be under one control. The refrigerator/freezer units were custom made for this project by Magna Kold, Inc., a commercial supplier of custom-built, high efficiency refrigerator units for marine and other special applications. These 15 refrigerator/freezers $(R / F)$ are installed in a locker-like arrangement of five cabinets. Each cabinet operates from a single compressor and contains three 4-ft ${ }^{3}$ R/F compartments (Figure 13). These units have COLD-PLATE* evaporators that use a phase change gel, special 3-in. polyurethane foam insulation around all sides, special door gaskets, and locking door latches. The five compressors are located under a protective shed-like cover on the outside of the north wall of the DSB (Figure 14). The White Zigzag sewing machine and the Maytag wringer washing machine are located in the DSB.

The PV system provides power for two 20-W fluorescent lights in each of the village homes and the DSB, 7 in the feast house, and 4 each in the church and EEB.

A Solahart Model 80 GE Solar Hotwater System is located on the roof of the DSB. This unit has a storage capacity of 80 gallons, works on the thermal siphon principle which eliminates the need for circulation pumps and operates at a normal pressure of 50 psi. It contains a $300-W$ resistance heater in the "cold" end of the collector to prevent water freeze-up in cold weather (Figure 15). The electric heater is thermostatically controlled to "on" at $36^{\circ} \mathrm{F}$ and "off" above $43^{\circ} \mathrm{F}$.

The Climatronics EWS is self-contained and does not derive its power for sensing or recording data from the main or $\mathrm{I} / \mathrm{C}$ power circuits. The EWS is equipped with a small photovoltaic module and a rechargeable battery which permits unattended operation. The EWS sensors and photovoltaic module are located within the fenced array area while the rechargeable battery and strip chart recorder are located in the EEB. The chart paper is replaced every 30 days and sent to NASA LeRC for data reduction.

In summary, the PV system provides power to four load circuits: the village water pump; lights in the homes, church, feast house, and EEB; the DSB which contains the refrigerators, a sewing machine, a washing machine, solar water heater freeze protection heater, and lights; and the instrumentation and controls.

\footnotetext{
${ }^{*}$ Patent Pending.
} 


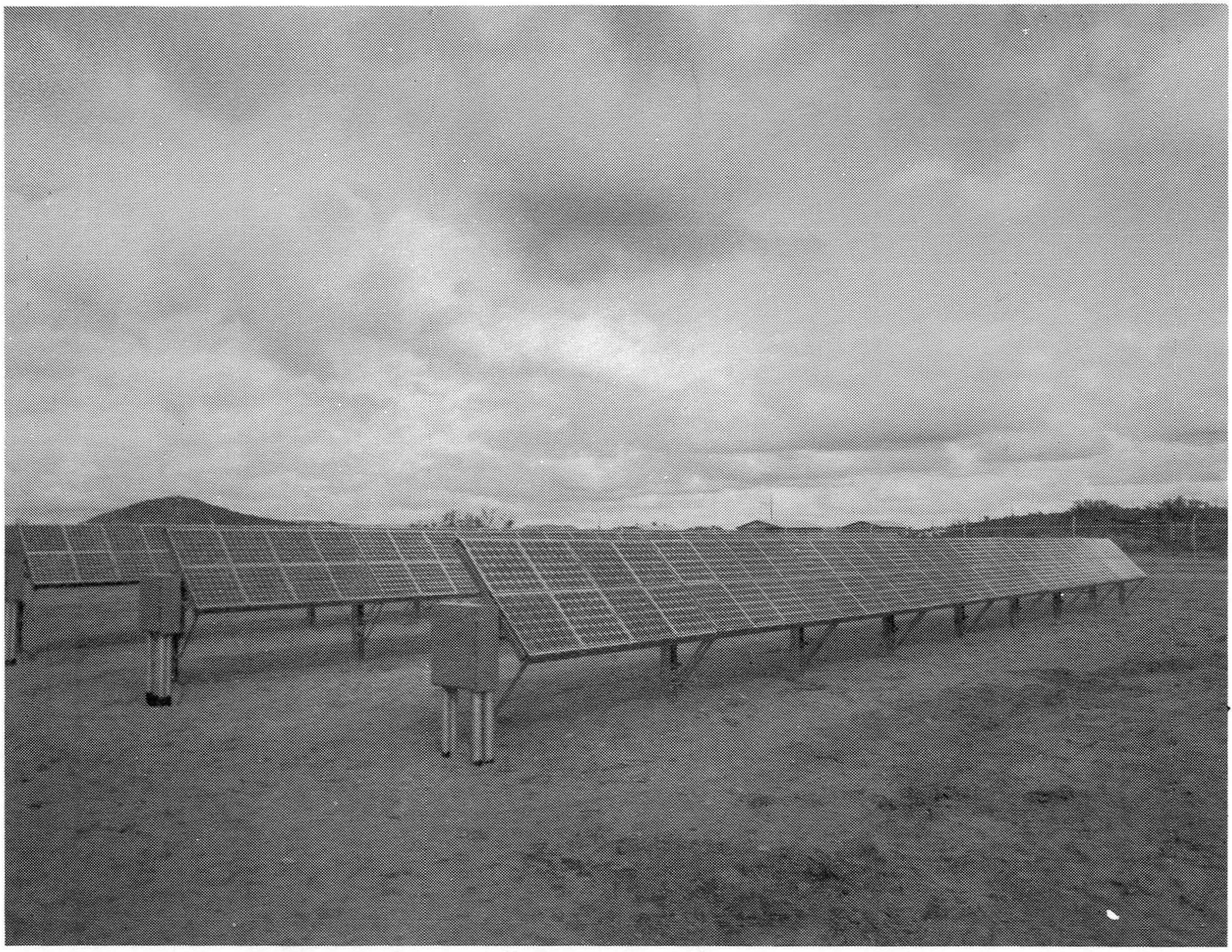

Figure 4. Array Field - 24 Panels 


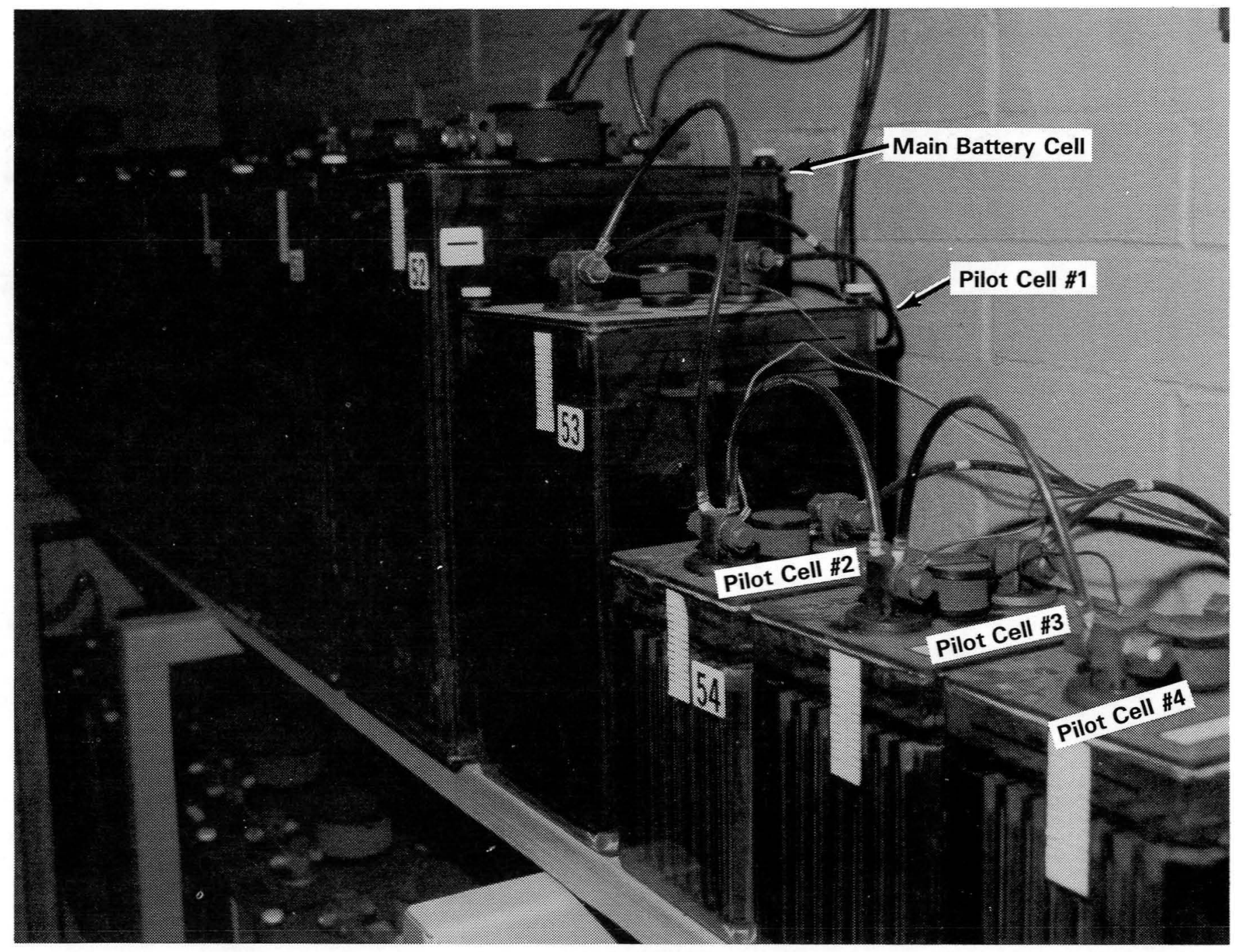

Figure 5. Main and Pilot Cell Batteries 


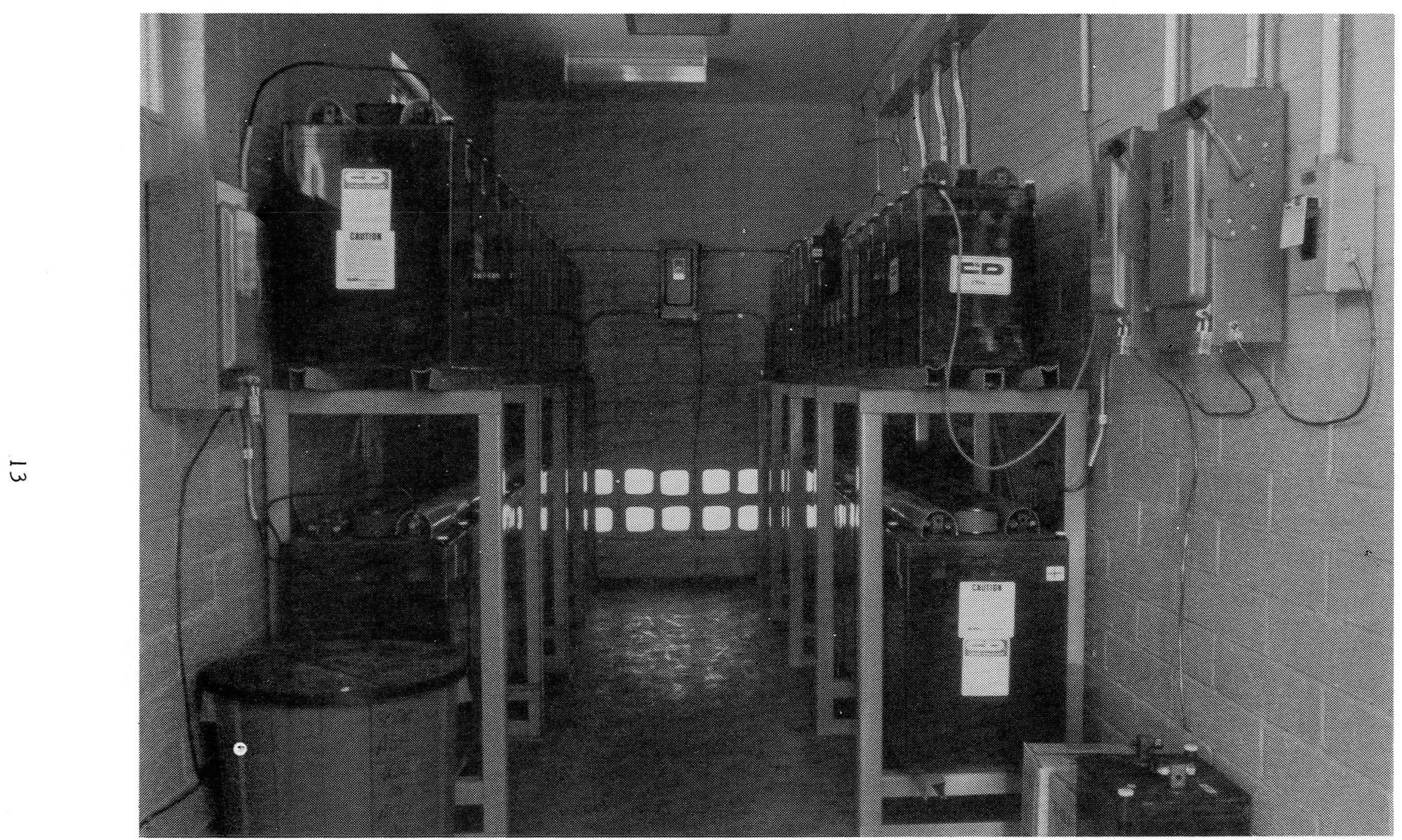

Figure 6. EEB Battery Room 


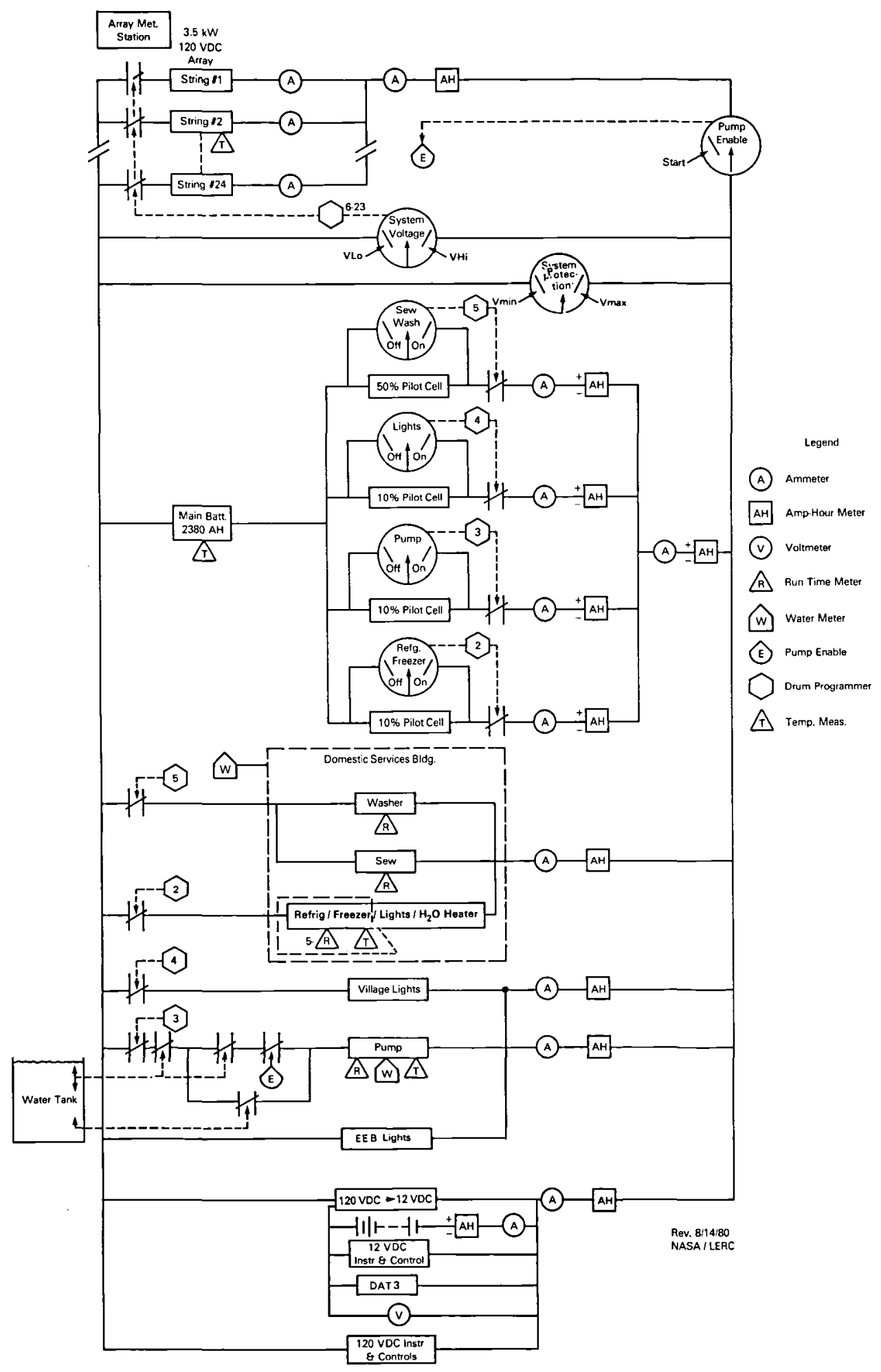

Figure 7. Schuchuli Village Power System Electrical Block Diagram 


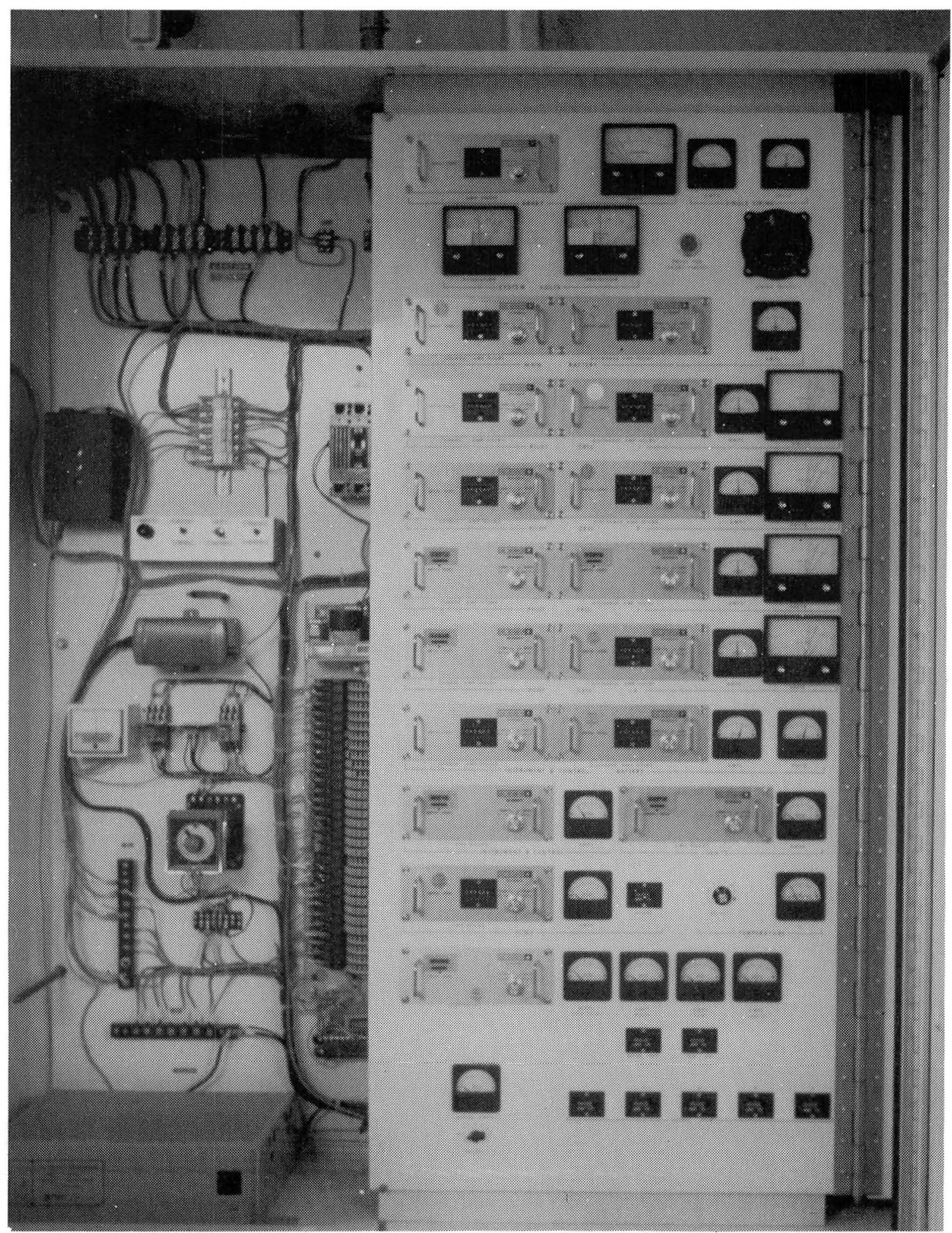

Figure 8. Power Collection, Control and Instrument Assembly Front View 
SCHUCHULI OAILY DATA SHEET

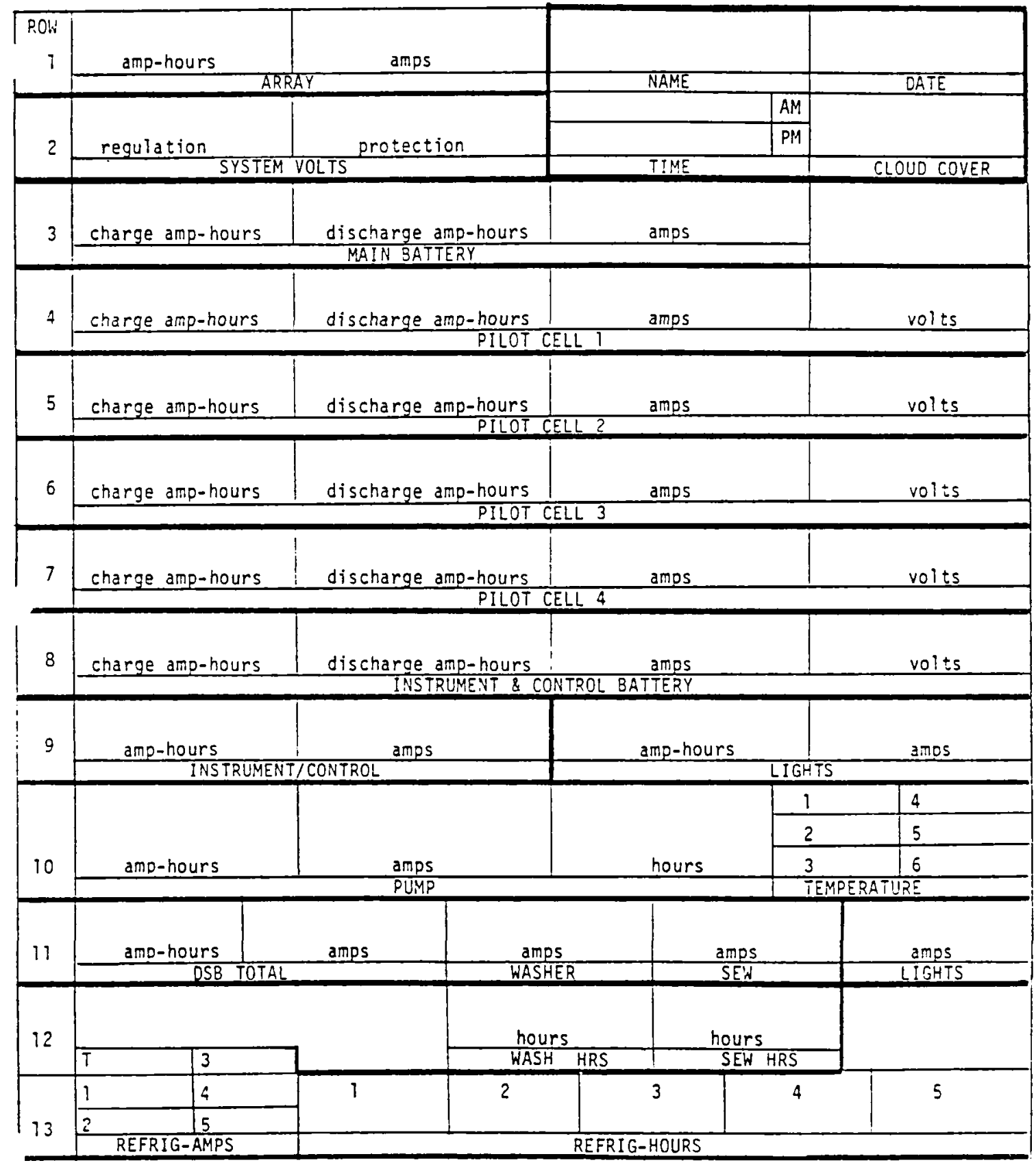

Figure 9. Prepared Data Sheet 
- Inside Panel of PCCIA:

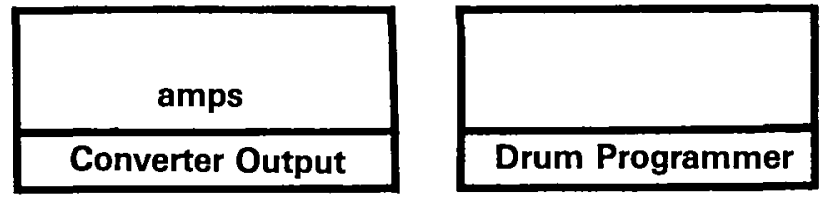

- Village Water Pump:

Gallons

- DSB Water Meter:

Gallons

Figure 9. Prepared Data Sheet (continued) 


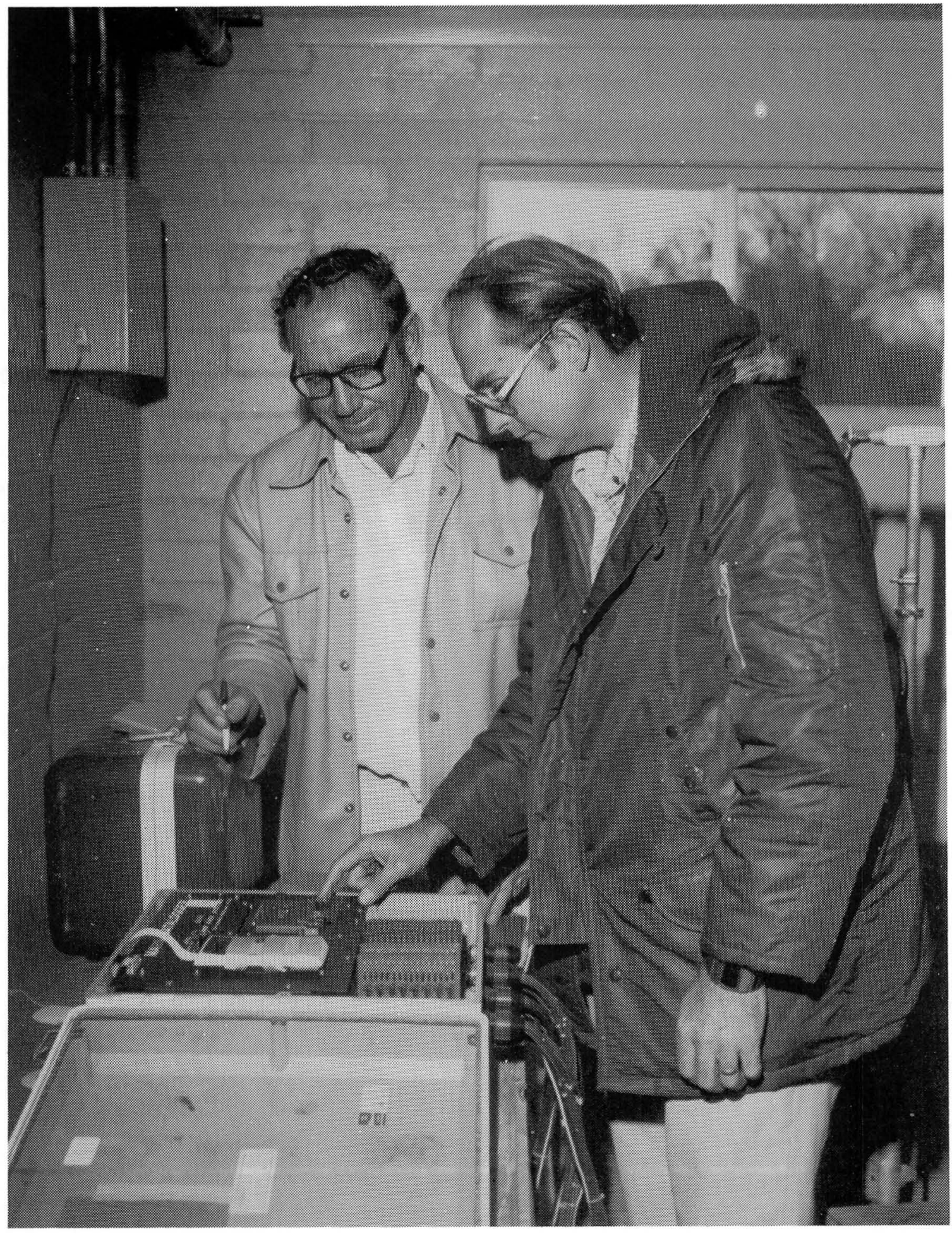

Figure 10. DAT-3 Auto Data Retrieval 
DAT-3 DATA PATTERN

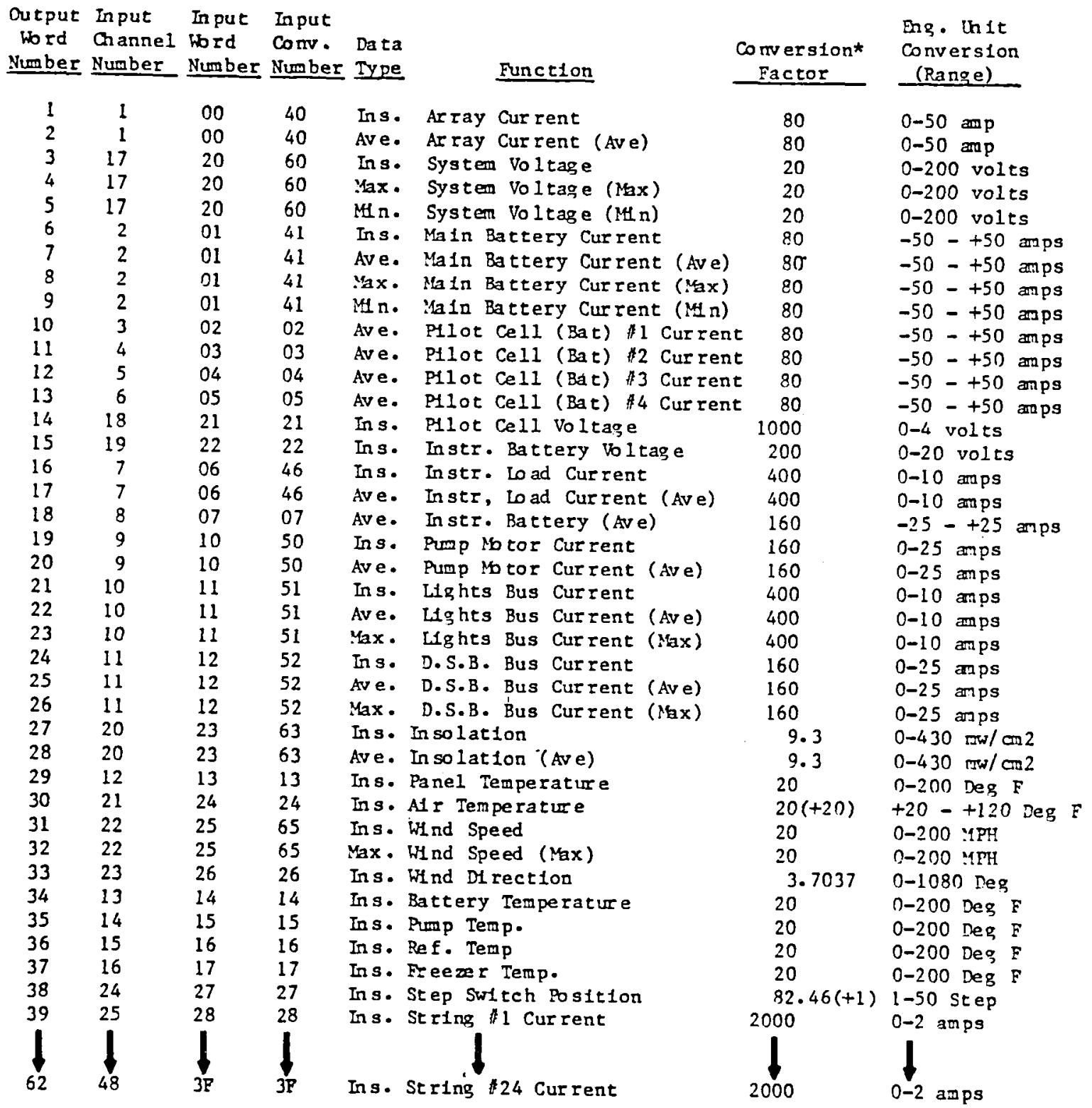

\footnotetext{
* For Bhineering thits: Divide counts by conversion Factor and add quantfty in ()
if there ts one.
}

Note; Th1s 11st1ng in DATPAT.SCHUCHUL Of SEDAT3.

Figure 11. Sample of Data 
Population:

Number of Service

Connections:

Water Supply:

Pumping Equipment:

Water Storage:
Approximately 96

19

Drilled well (a dug well is used as a standby)

Diameter:

8 inches

Depth:

243 feet

Static Water

Level:

48 feet

Well Capacity: 29 gpm

Pumping Level: 125 feet

Jensen Jack Model 125 DC

Cylinder:

1.75 inches diameter

Pumping Capacity:

$18.7 \mathrm{gpm}$

Drop Pipe:

3 inches diameter

Total Dynamic Head:

175 feet

Power Required:

2 hp (pump manufacturer's recommendation)

Note: 7 hp single cylinder diesel engine previously used.

11,000 gallon capacity steel storage tank

- approximately 8 feet diameter

- approximately 30 feet high 


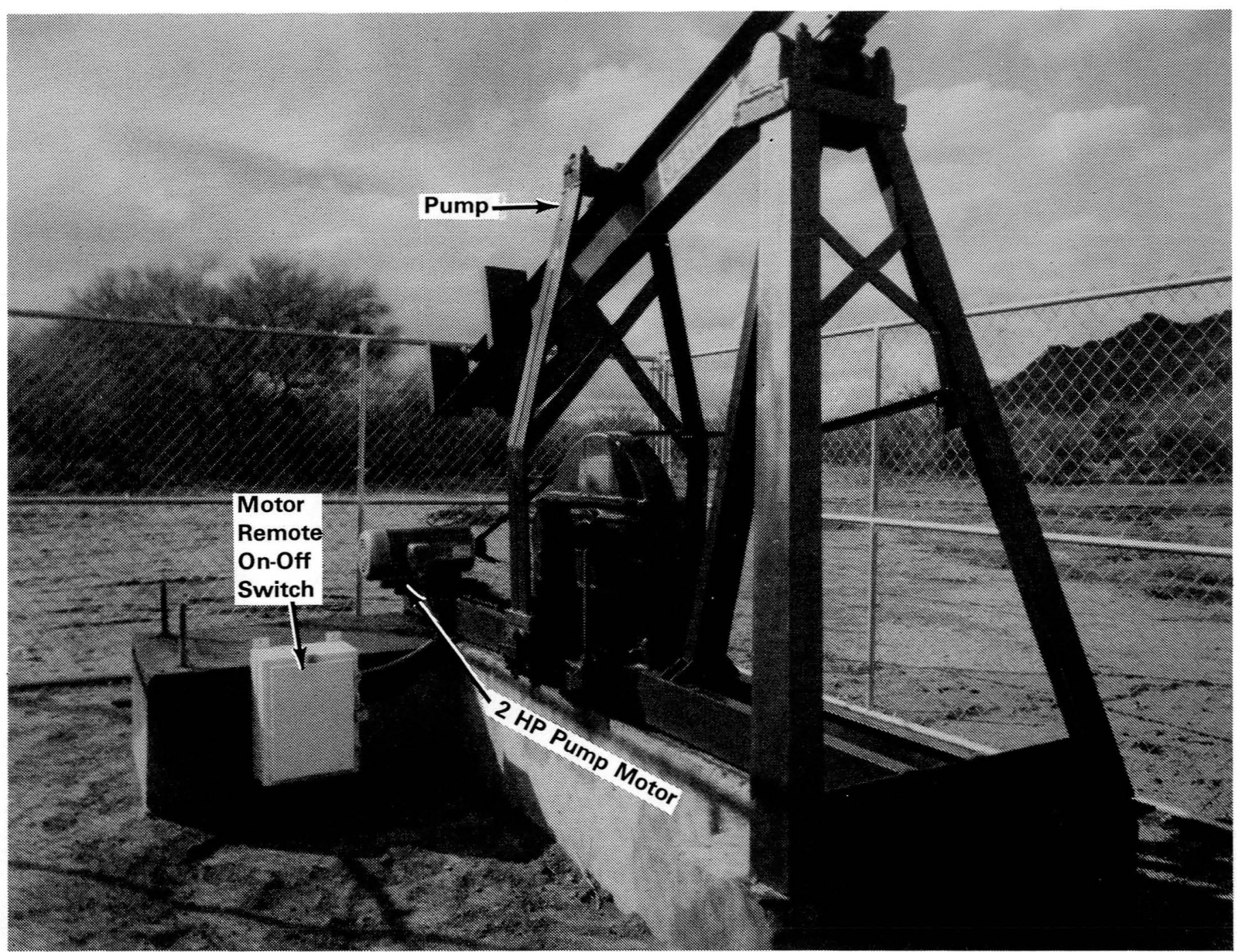

Figure 12. Water Pump 


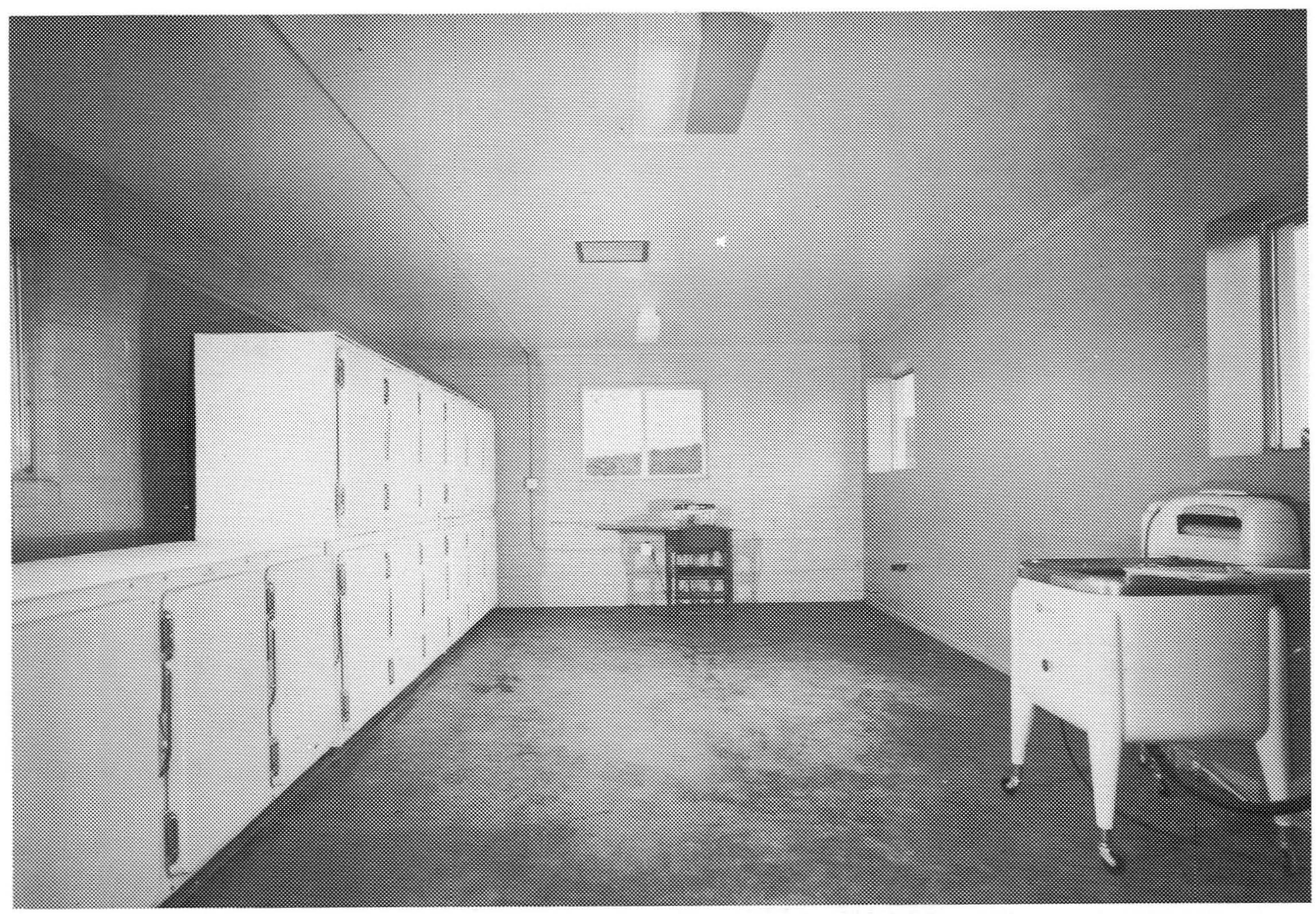

Figure 13. Refrigerator/Freezer Units Located in the DSB 


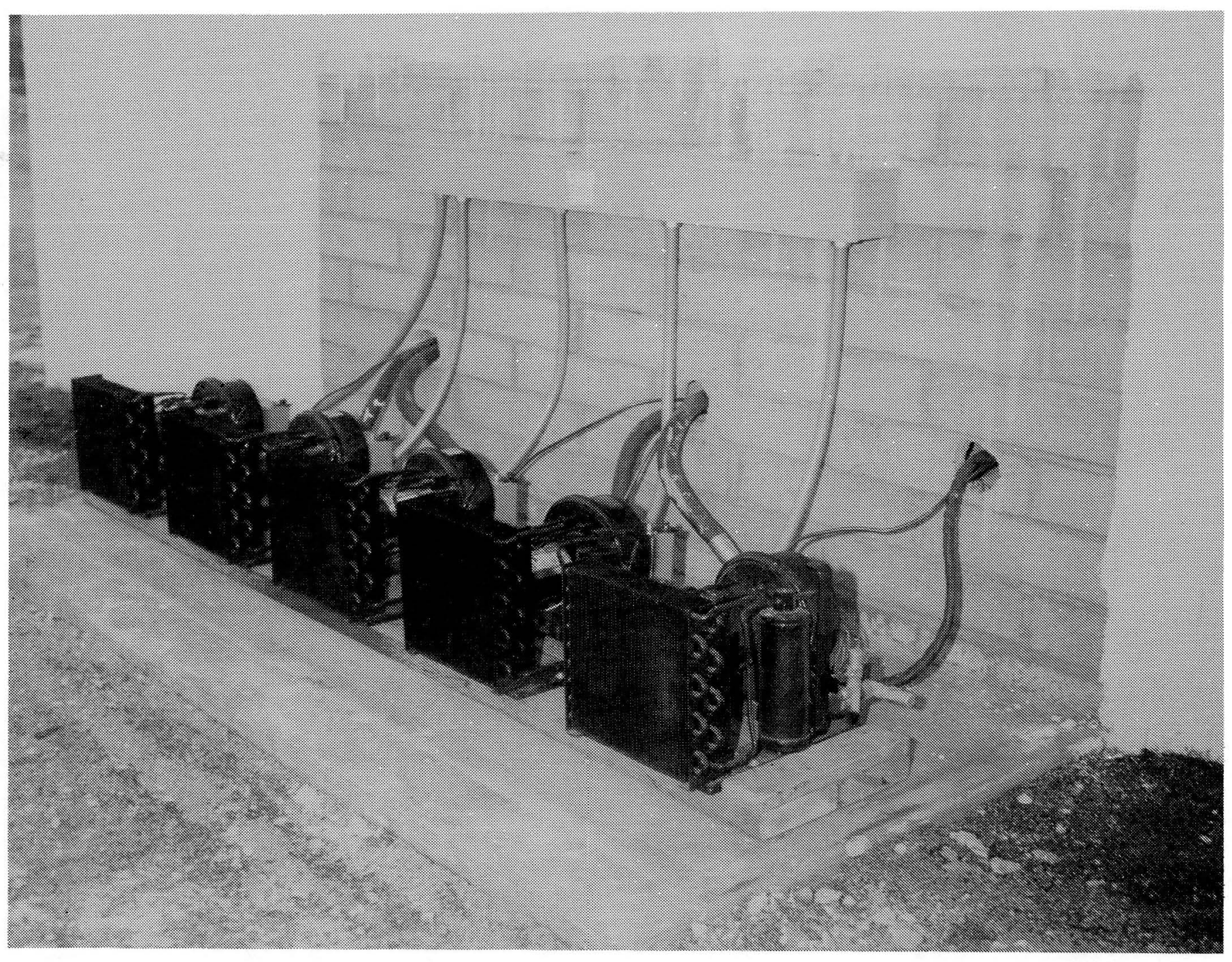

Figure 14. Refrigerator/Freezer Compressors 


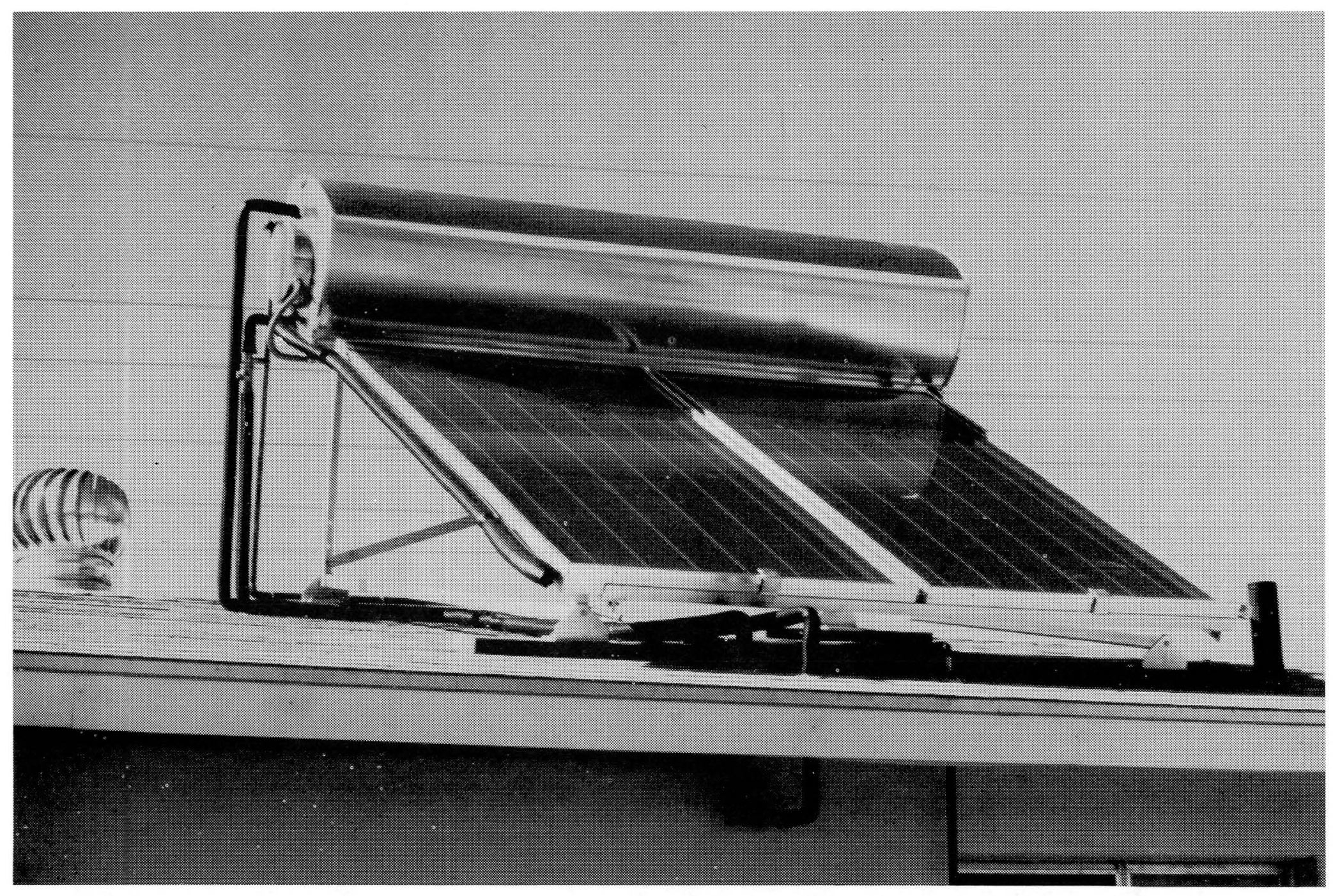

Figure 15. Solahart Solar Water Heater System 


\section{SYSTEM DESIGN}

\section{LOAD AND LOAD PROFILES}

\section{General}

As previously stated, the PV system provides power to four load circuits: the village water pump; lights in the homes, church, feast house, and EEB; the DSB which contains the refrigerators, a sewing machine, a washing machine, solar thermal water heater freeze protection heater, and lights; and the instrumentation and controls. All loads are $120 \mathrm{~V}\left(\mathrm{~d}_{\text {.c. }}\right.$ ) except for the instrumentation and some controls which are $12 \mathrm{~V}$ (d.c.). These loads were jointly selected by the participating organizations including the villagers themselves. The selection of specific loads was strongly influenced by the desire to maximize the energy efficiency of the loads and the cost benefits, i.e., high efficiency d.c. motors, high lumen efficiency lights, extra thermal insulation on refrigerator/freezers, low power consumption of instrumentation and controls. Throughout, safety of operation and ease of maintenance were foremost in mind. Early operating experience prompted the village women to request heated water for the laundry and a solar thermal hot water unit was obtained and installed on the roof of the DSB. Also, three additional homes were wired for lights following initial operation of the system. These changes were minor and have had little or no effect on the overall system operation.

\section{Water Pump}

The Public Health Service provided the estimated village water consumption data (exclusive of the washing machine) and NASA LeRC estimated the water use for the washing machine (Table 2). Based on a projected growth in population to 112 and an estimated 1.5 washer loads per person per week with an estimated 40 gallons of water used per load, the resulting projected use is approximately 960 gallons per day. This means that the machine would average two loads per hour over the 12-hour day, 8:00 a.m. to $8: 00$ p.m. Table 2 also lists the load estimates for the water pump motor based on the 2-hp motor at full pumping rate drawing approximately 15.5 amperes.

\section{Village Lights}

The PV system provides power for two 20-W fluorescent lights in each of the village homes and the DSB, 7 in the feast house, and 4 each in the church and EEB. The lights in the feast house, church, EEB, and DSB are for occasional usage and were not included in the design load profile. The house lighting profile for the original 15 homes is shown in Table 3 and was estimated by NASA LeRC based on information from PHS and the village chairman. Each 20-W lamp operates from a special Bodine Co. "Tran-Bal" inverter-ballast which inverts the $120 \mathrm{~V}\left(\right.$ d.c. $_{\text {. }}$ to $120 \mathrm{~V}($ a.c. $) / 23 \mathrm{kHz}$. Inverter-ballast current requirements were forecast by the manufacturer as 
0.241 amperes. Each light uses a standard $120 \mathrm{~V}$ (a.c.) fluorescent lamp and a standard light fixture substituting the inverter ballast for the standard ballast. The home lighting schedule of Table 3 was based on 0.241 amperes per light, 2 lights per home, 15 homes and a use factor of 80 percent. Thus the lighting load current during periods when lights were assumed to be in use was estimated to be $(0.241 \times 2 \times 15 \times 0.80)=5.78$ amperes.

Washing Machine Motor

The washing machine is located in the DSB and is a Maytag wringer model with an Applied Motors $120 \mathrm{~V}$ (d.c.), permanent magnet, 1/4-hp motor drawing approximately 2.59 amperes when operating at full load. Washing machine use was scheduled on the basis of 1.5 washer loads per person per week for a projected population of 112 meaning the machine would average two loads per hour for 12 hours each day. Thus, the washing machine motor was estimated to draw an average of 31.08 ampere-hours per day.

\section{Solar Hot Water Heater}

This unit was not part of the original design but was added to the system in June 1979 to provide hot water to the DSB in response to the women's reluctance to use cold water in the washing machine. It is a Solahart Model 80 GE Solar Hotwater System, located on the roof of the DSB. It contains a $300-\mathrm{W}$ resistance heater in the "cold" end of the collector to prevent water freeze-up in cold weather. There is no other electric heating of the water. This electric load was not included in the original design load profiles but was considered within the capabilities of the PV system when the water heater was added to the system based largely on less than planned use of the washing machine.

Sewing Machine

The sewing machine is also located in the DSB and is a white Zigzag Model with a $1 / 8$-hp universal motor drawing approximately 1.1 amperes at $120 \mathrm{~V}(\mathrm{~d} . \mathrm{c}$.$) . It was assumed that the sewing machine would be used an$ average of 3 hours per day, 5 days per week, with the motor running approximately 70 percent of the time. Thus, the sewing was estimated to use an average of 2.3 ampere-hours per day.

\section{Refrigerators}

The 15 refrigerator/freezers are installed in a locker-like arrangement of five cabinets, each cabinet operating from a single compressor. The five compressors, located under a protective cover on the outside of the north wall of the DSB, are driven by 1/4-hp P.M. d.c. motors drawing 1.45 amperes each. Table 4 indicates the estimate of the power consumption for these refrigerators on this basis. 
Instruments and Controls

The instrument and controls load includes all of the 12-V(d.c.) instruments and controls and the $120-\mathrm{V}$ (d.c.) controls with the exception of the Climatronics EWS which is independent of the PV power system. Power flow is governed and regulated and voltage and currents are measured in the Power Collection, Controls, and Instrument Assembly (PCCIA) located in the EEB (Figure 8, and Figures 16 through 20). The starter controls for the 2-hp pump motor are located in the EEB (Figure 21). Some load shedding controls and current measuring shunts are in the DSB control panel (Figure 22). A DAT-3 auto data recorder is located in the EEB. As previously stated, the I/C battery furnishes $12-\mathrm{V}$ (d.c.) power to the PCCIA panel in the EEB, the control panel in the DSB, and the DAT-3 in the EEB. The I/C battery consists of six C\&D KCPSA-15 cells rated at $1055 \mathrm{AH}$ each and is kept charged from the main battery through a d.c./d.c. converter.

The estimated I/C current requirements are shown in Table 5.

\section{Combined Load Profile}

Combining all of the above described loads for each hour, day, and month produced the detailed loads profile which was used to simulate the system operation and determine PV array size $\left(\mathrm{kW}_{\mathrm{pk}}\right)$ and battery capacity. Samples of combined load profiles are shown for typical days in Table 6. 
Table 2. Water Pump Load Profile

\begin{tabular}{|l|c|c|c|c|c|}
\hline \multicolumn{1}{|c|}{ Month } & $\begin{array}{c}\text { Village } \\
\text { Water Consumption } \\
\text { (Excluding } \\
\text { Washing Machine) } \\
\text { Gal/ Day }\end{array}$ & $\begin{array}{c}\text { Washing } \\
\text { Machine } \\
\text { Water } \\
\text { Consumption } \\
\text { Gal/ Day }\end{array}$ & $\begin{array}{c}\text { Total } \\
\text { Gallons } \\
\text { Per Day }\end{array}$ & $\begin{array}{c}\text { Pump } \\
\text { Hours/Day }\end{array}$ & $\begin{array}{c}\text { Pump Motor } \\
\text { Ampere-Hours/Day * }\end{array}$ \\
\hline January & 1500 & 960 & 2460 & 2.25 & 34.9 \\
February & 1500 & 960 & 2460 & 2.25 & 34.9 \\
March & 2500 & 960 & 3460 & 3.17 & 49.1 \\
April & 2500 & 960 & 3460 & 3.17 & 49.1 \\
May & 4000 & 960 & 4960 & 4.54 & 70.4 \\
June & 4000 & 960 & 4960 & 4.54 & 70.4 \\
July & 4000 & 960 & 4960 & 4.54 & 70.4 \\
August & 4000 & 960 & 4960 & 4.54 & 70.4 \\
September & 2500 & 960 & 3460 & 3.17 & 49.1 \\
October & 2500 & 960 & 3460 & 3.17 & 49.1 \\
November & 1500 & 960 & 2460 & 2.25 & 34.9 \\
December & 1500 & 960 & 2460 & 2.25 & 34.9 \\
\hline
\end{tabular}

*Pump motor current assumed to be 15.5 amperes. 
Table 3. House Lighting Load Profile

\begin{tabular}{|l|c|c|c|c|}
\hline \multirow{2}{*}{ Month } & \multicolumn{2}{|c|}{ Operating Hours } & \multirow{2}{*}{$\begin{array}{c}\text { Total Hours } \\
\text { Average Per Day }\end{array}$} & $\begin{array}{c}\text { Ampere-Hours } \\
\text { Average Per Day * }\end{array}$ \\
\cline { 2 - 3 } January & AM & PM & 7.5 & 43.4 \\
February & $6: 00-8: 30$ & $5: 00-10: 00$ & 6.5 & 37.6 \\
March & $6: 00-7: 30$ & $5: 00-10: 00$ & 4.5 & 26.0 \\
April & $6: 00-6: 30$ & $6: 00-10: 00$ & 3.0 & 17.4 \\
May & - & $7: 00-10: 00$ & 3.0 & 17.4 \\
June & - & $8: 00-11: 00$ & 2.0 & 11.6 \\
July & - & $9: 00-11: 00$ & 2.0 & 11.6 \\
August & - & $9: 00-11: 00$ & 3.0 & 17.4 \\
September & $6: 00-6: 30$ & $8: 00-11: 00$ & 3.5 & 20.2 \\
October & $6: 00-7: 30$ & $6: 00-10: 00$ & 5.5 & 31.8 \\
November & $6: 00-7: 30$ & $5: 00-10: 00$ & 6.5 & 37.6 \\
December & $6: 00-8: 30$ & $5: 00-10: 00$ & 7.5 & 43.4 \\
\hline
\end{tabular}

"Based on 0.241 amperes/lamp;

Assumes $80 \%$ use factor during operating hours. 
Table 4. Refrigerator/Freezer Load Profile

\begin{tabular}{|l|c|c|c|}
\hline Month & $\begin{array}{c}\text { Maximum } \\
\left.\text { Temperature }{ }^{\circ} \mathrm{F}\right)\end{array}$ & $\begin{array}{c}\text { Average } \\
\text { Amperage }\end{array}$ & $\begin{array}{c}\text { Average Daily } \\
\text { Ampere-Hours * }\end{array}$ \\
\hline January & 69 & 0.634 & 15.22 \\
February & 74 & 0.743 & 17.83 \\
March & 81 & 0.888 & 21.31 \\
April & 88 & 1.106 & 26.54 \\
May & 96 & 1.323 & 31.75 \\
June & 103 & 1.577 & 37.85 \\
July & 108 & 1.758 & 42.20 \\
August & 107 & 1.740 & 41.76 \\
September & 103 & 1.577 & 37.85 \\
October & 92 & 1.178 & 28.27 \\
November & 79 & 0.852 & 20.45 \\
December & 71 & 0.671 & 16.10 \\
\hline
\end{tabular}

*For 5 compressors. 


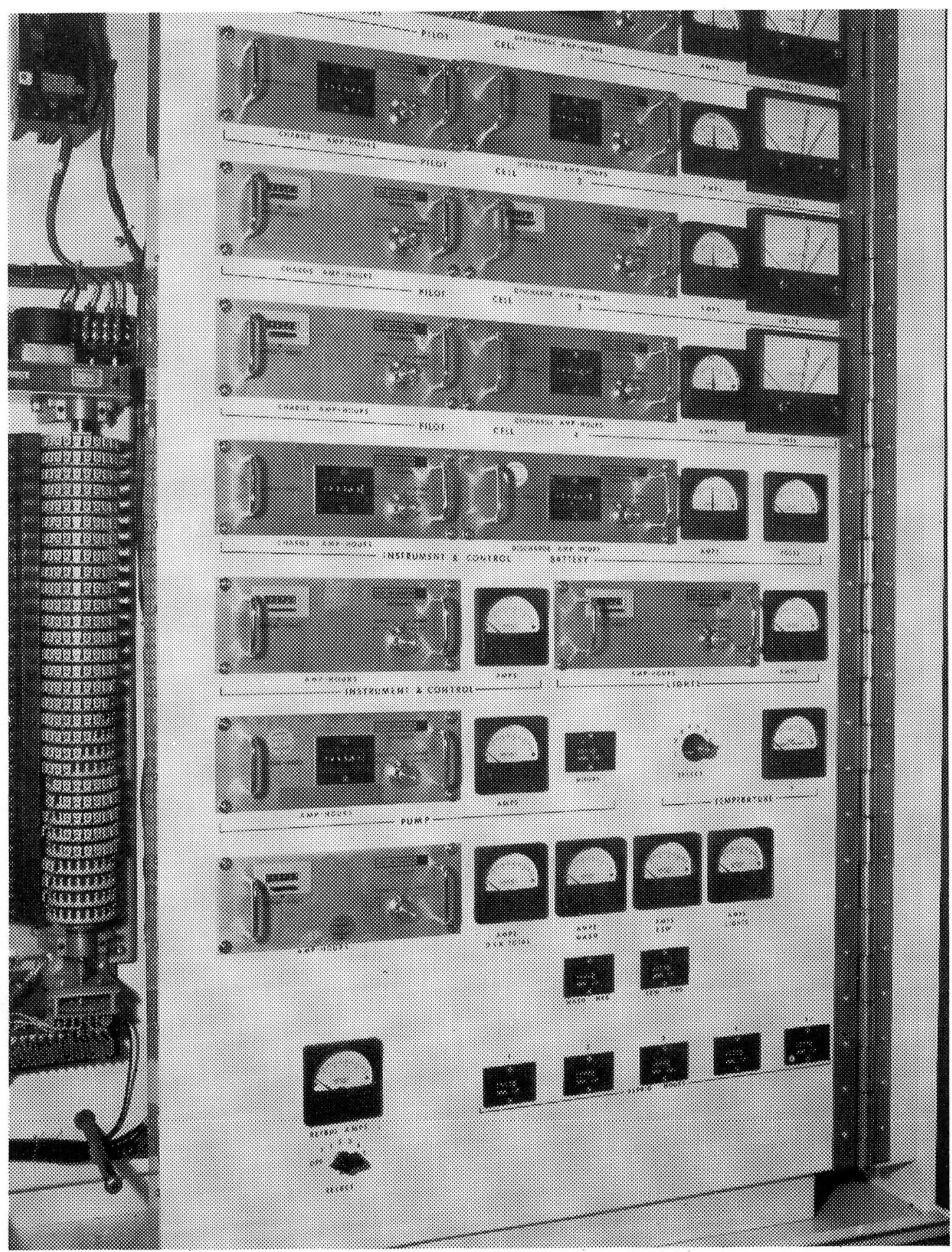

Figure 16. PCCIA Panel Meters 


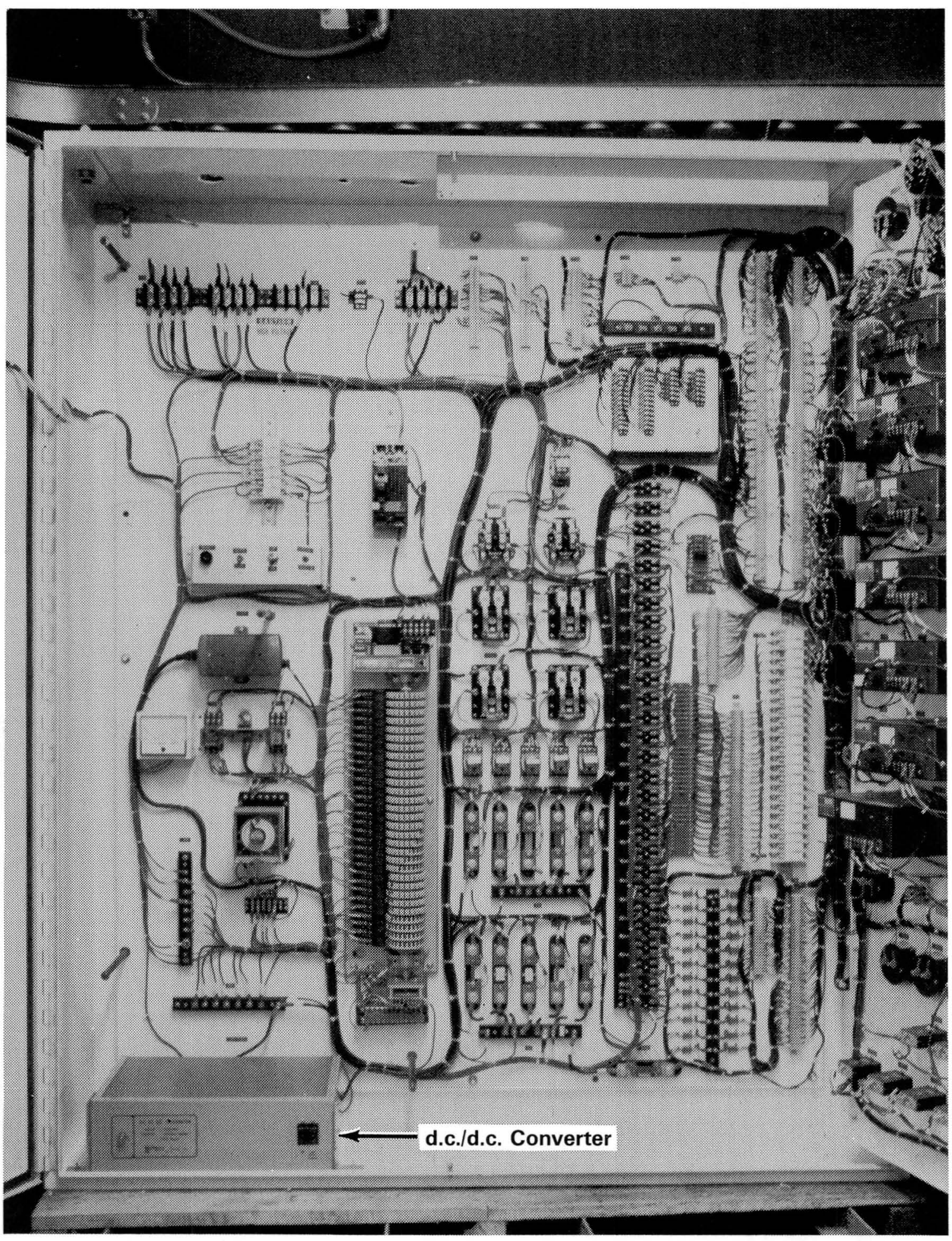

Figure 17. PCCIA Power and Control 


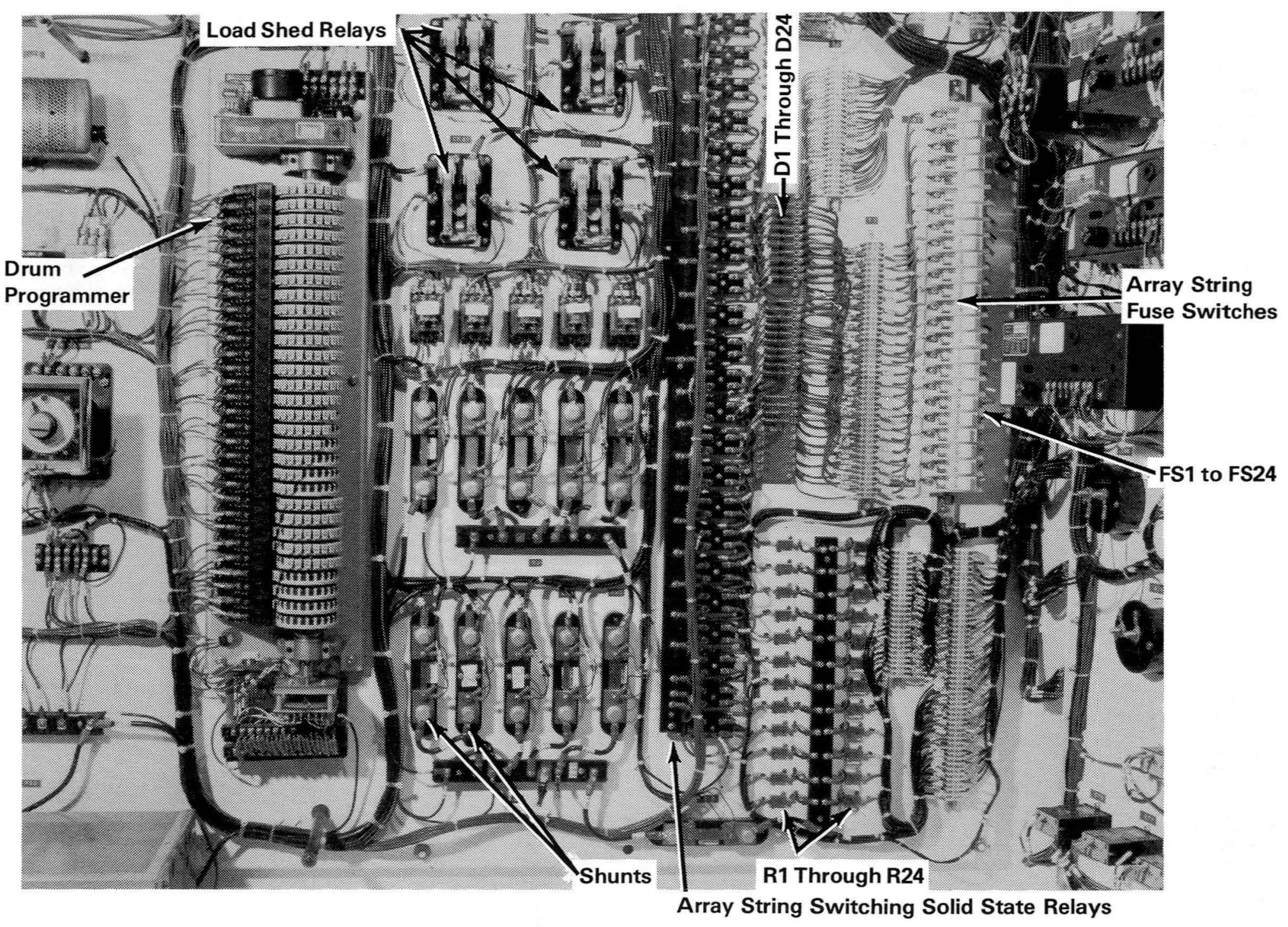

Figure 18. PCCIA 


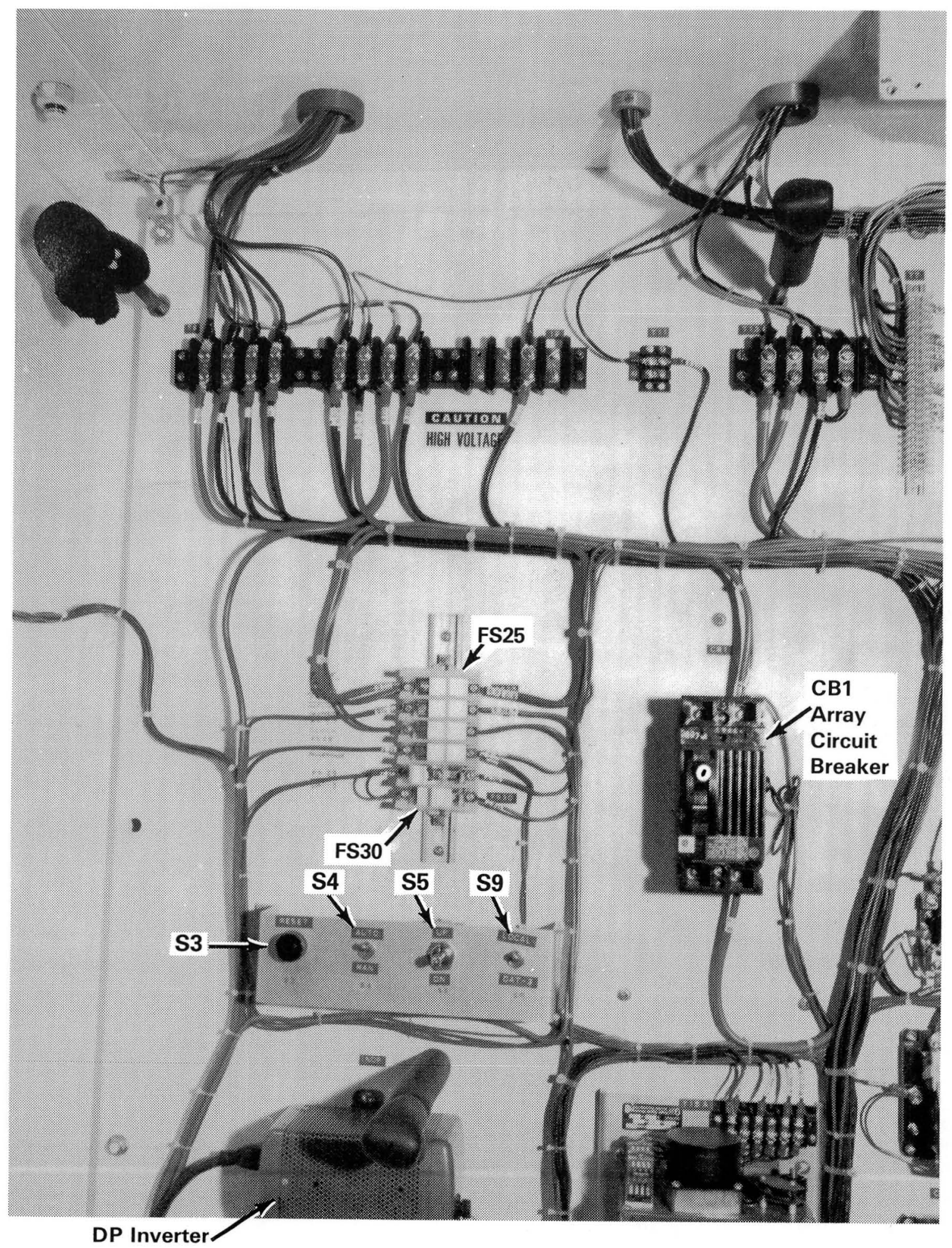

Figure 19. PCCIA 


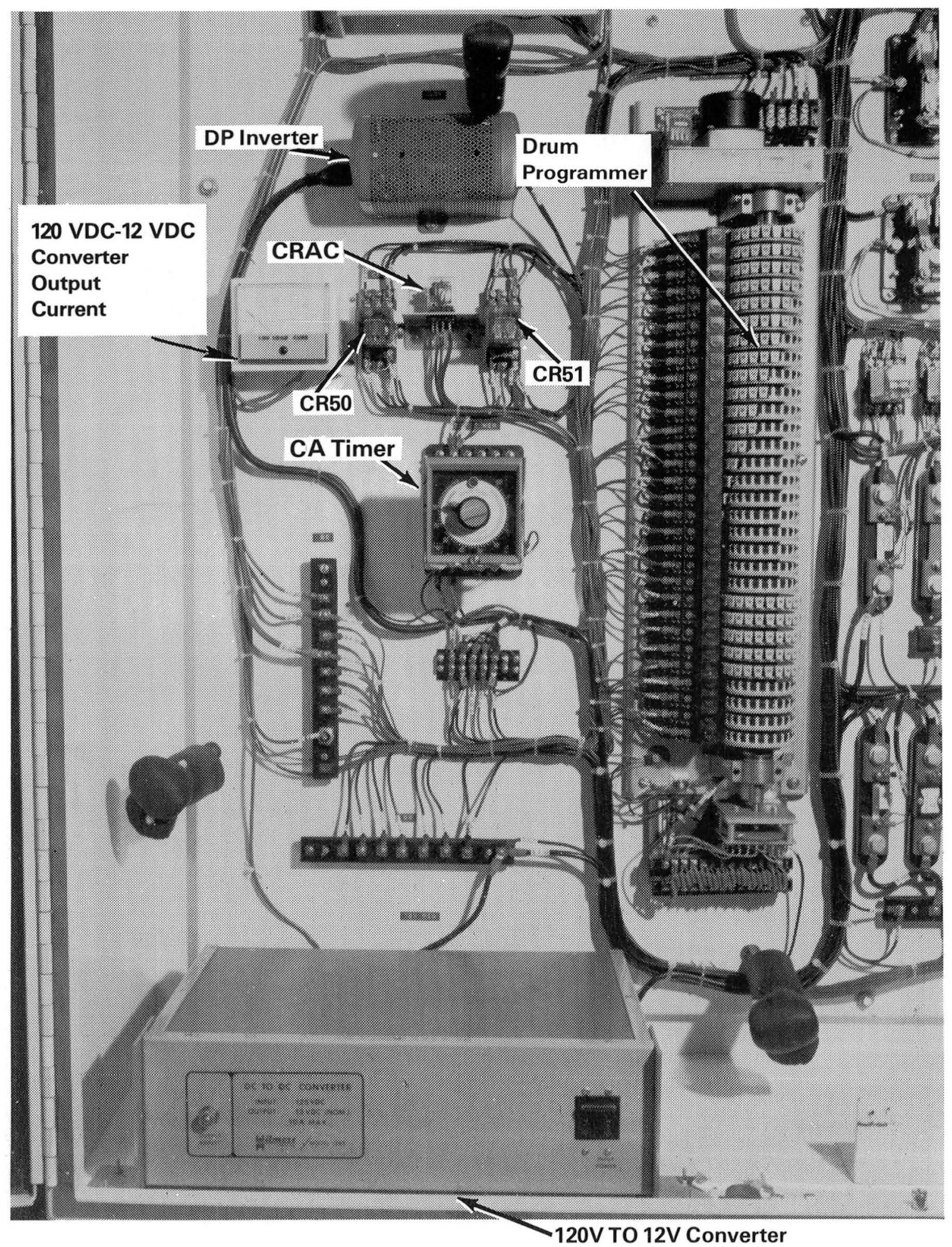

Figure 20. PCCIA 


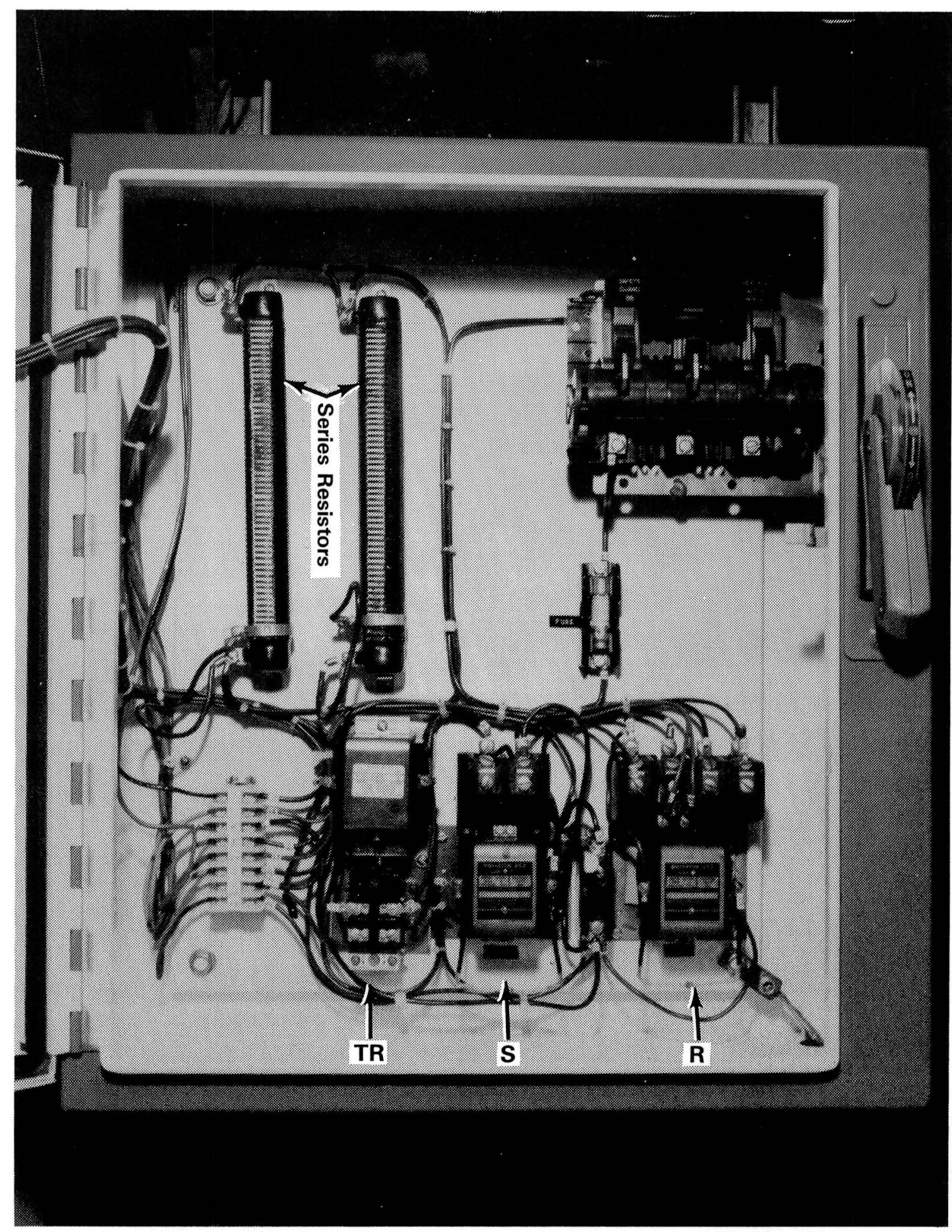

Figure 21. 2 HP Motor Starter Control Panel 


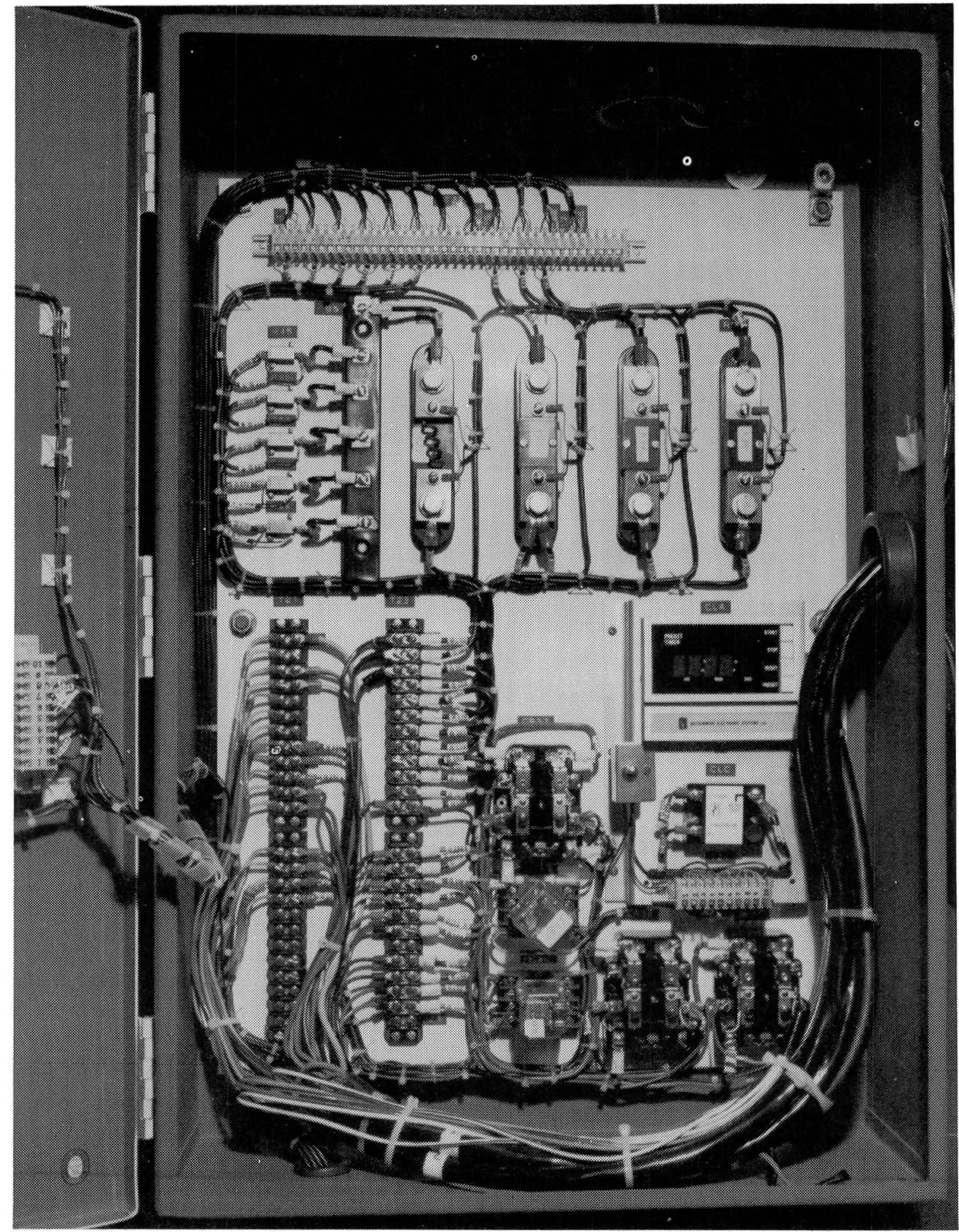

Figure 22. DSB Control Panel 
Table 5. Instrument and Controls Load Profile

\begin{tabular}{|l|c|c|}
\hline Month & $\begin{array}{c}\text { Average Amperage } \\
\text { @ 120V (d.c.) }\end{array}$ & $\begin{array}{c}\text { Average Daily } \\
\text { Ampere-Hours }\end{array}$ \\
\hline January & 0.543 & 13.04 \\
February & 0.530 & 12.72 \\
March & 0.579 & 13.90 \\
April & 0.591 & 14.19 \\
May & 0.645 & 15.48 \\
June & 0.645 & 15.48 \\
July & 0.579 & 13.90 \\
August & 0.579 & 13.90 \\
September & 0.579 & 13.90 \\
October & 0.579 & 13.90 \\
November & 0.562 & 13.50 \\
December & 0.543 & 13.04 \\
\hline
\end{tabular}


Table 6. Typical Load Profiles, Amperes-Hours/Hour

Mid-September (Mid-March is similar)

\begin{tabular}{|c|c|c|c|c|c|c|c|}
\hline Hour & $\begin{array}{l}\text { Pump } \\
\text { Motor }\end{array}$ & Lights & $\begin{array}{l}\text { Washing } \\
\text { Machine }\end{array}$ & $\begin{array}{l}\text { Sewing } \\
\text { Machine }\end{array}$ & $\begin{array}{c}\text { Refrigerators } \\
\text { (Average Amps) }\end{array}$ & $\begin{array}{l}\text { Instruments } \\
\text { and Controls }\end{array}$ & $\begin{array}{c}\text { Amperes } \\
\text { Total }\end{array}$ \\
\hline 1 & & & & & 1.577 & 0.579 & 2.156 \\
\hline 2 & & & & & 1.577 & 0.579 & 2.156 \\
\hline 3 & & & & & 1.577 & 0.579 & 2.156 \\
\hline 4 & & & & & 1.577 & 0.579 & 2.156 \\
\hline 5 & & & & & 1.577 & 0.579 & 2.156 \\
\hline 6 & & & & & 1.577 & 0.579 & 2.156 \\
\hline 7 & & 2.88 & & & 1.577 & 0.579 & 5.036 \\
\hline 8 & & & & & 1.577 & 0.579 & 2.156 \\
\hline 9 & & & 2.59 & & 1.577 & 0.579 & 4.746 \\
\hline 10 & & & 2.59 & & 1.577 & 0.579 & 4.746 \\
\hline 11 & 9.05 & & 2.59 & & 1.577 & 0.579 & 13.796 \\
\hline 12 & 15.50 & & 2.59 & & 1.577 & 0.579 & 20.246 \\
\hline 13 & 15.50 & & 2.59 & & 1.577 & 0.579 & 20.246 \\
\hline 14 & 9.05 & & 2.59 & 0.77 & 1.577 & 0.579 & 14.566 \\
\hline 15 & & & 2.59 & 0.77 & 1.577 & 0.579 & 5.516 \\
\hline 16 & & & 2.59 & 0.77 & 1.577 & 0.579 & 5.516 \\
\hline 17 & & & 2.59 & & 1.577 & 0.579 & 4.746 \\
\hline 18 & & & 2.59 & & 1.577 & 0.579 & 4.746 \\
\hline 19 & & & 2.59 & & 1.577 & 0.579 & 4.746 \\
\hline 20 & & 6.23 & 2.59 & & 1.577 & 0.579 & 10.976 \\
\hline 21 & & 5.75 & & & 1.577 & 0.579 & 7.906 \\
\hline 22 & & 5.75 & & & 1.577 & 0.579 & 7.906 \\
\hline 23 & & & & & 1.577 & 0.579 & 2.156 \\
\hline 24 & & & & & 1.577 & 0.579 & 2.156 \\
\hline
\end{tabular}


Mid-December

Table 6. Typical Load Profiles, Amperes-Hours/Hour (continued)

\begin{tabular}{|c|c|c|c|c|c|c|c|}
\hline Hour & $\begin{array}{l}\text { Pump } \\
\text { Motor }\end{array}$ & Lights & $\begin{array}{l}\text { Washing } \\
\text { Machine }\end{array}$ & $\begin{array}{l}\text { Sewing } \\
\text { Machine }\end{array}$ & $\begin{array}{c}\text { Refrigerators } \\
\text { (Average Amps) }\end{array}$ & $\begin{array}{l}\text { Instruments } \\
\text { and Controls }\end{array}$ & $\begin{array}{c}\text { Amperes } \\
\text { Total }\end{array}$ \\
\hline 1 & & & & & 0.671 & 0.543 & 1.214 \\
\hline 2 & & & & & 0.671 & 0.543 & 1.214 \\
\hline 3 & & & & & 0.671 & 0.543 & 1.214 \\
\hline 4 & & & & & 0.671 & 0.543 & 1.214 \\
\hline 5 & & & & & 0.671 & 0.543 & 1.214 \\
\hline 6 & & & & & 0.671 & 0.543 & 1.214 \\
\hline 7 & & 5.75 & & & 0.671 & 0.543 & 6.964 \\
\hline 8 & & 5.75 & & & 0.671 & 0.543 & 6.964 \\
\hline 9 & & 3.11 & 2.59 & & 0.671 & 0.543 & 6.914 \\
\hline 10 & & & 2.59 & & 0.671 & 0.543 & 3.804 \\
\hline 11 & 1.95 & & 2.59 & & 0.671 & 0.543 & 5.754 \\
\hline 12 & 15.50 & & 2.59 & & 0.671 & 0.543 & 19.304 \\
\hline 13 & 15.50 & & 2.59 & & 0.671 & 0.543 & 19.304 \\
\hline 14 & 1.95 & & 2.59 & 0.77 & 0.671 & 0.543 & 6.524 \\
\hline 15 & & & 2.59 & 0.77 & 0.671 & 0.543 & 4.574 \\
\hline 16 & & & 2.59 & 0.77 & 0.671 & 0.543 & 4.574 \\
\hline 17 & & & 2.59 & & 0.671 & 0.543 & 3.804 \\
\hline 18 & & 6.23 & 2.59 & & 0.671 & 0.543 & 10.034 \\
\hline 19 & & 6.23 & 2.59 & & 0.671 & 0.543 & 10.034 \\
\hline 20 & & 6.23 & 2.59 & & 0.671 & 0.543 & 10.034 \\
\hline 21 & & 5.75 & & & 0.671 & 0.543 & 6.964 \\
\hline 22 & & 5.75 & & & 0.671 & 0.543 & 6.964 \\
\hline 23 & & & & & 0.671 & 0.543 & 1.214 \\
\hline 24 & & & & & 0.671 & 0.543 & 1.214 \\
\hline
\end{tabular}


Table 6. Typical Load Profiles, Amperes-Hours/Hour (continued)

Mid-July

\begin{tabular}{|c|c|c|c|c|c|c|c|}
\hline Hour & $\begin{array}{l}\text { Pump } \\
\text { Motor }\end{array}$ & Lights & $\begin{array}{l}\text { Washing } \\
\text { Machine }\end{array}$ & $\begin{array}{l}\text { Sewing } \\
\text { Machine }\end{array}$ & $\begin{array}{c}\text { Refrigerators } \\
\text { (Average Amps) }\end{array}$ & $\begin{array}{l}\text { Instruments } \\
\text { and Controls }\end{array}$ & $\begin{array}{c}\text { Amperes } \\
\text { Total }\end{array}$ \\
\hline 1 & & & & & 1.758 & 0.579 & 2.337 \\
\hline 2 & & & & & 1.758 & 0.579 & 2.337 \\
\hline 3 & & & & & 1.758 & 0.579 & 2.337 \\
\hline 4 & & & & & 1.758 & 0.579 & 2.337 \\
\hline 5 & & & & & 1.758 & 0.579 & 2.337 \\
\hline 6 & & & & & 1.758 & 0.579 & 2.337 \\
\hline 7 & & & & & 1.758 & 0.579 & 2.337 \\
\hline 8 & & & & & 1.758 & 0.579 & 2.337 \\
\hline 9 & & & 2.59 & & 1.758 & 0.579 & 4.927 \\
\hline 10 & 4.20 & & 2.59 & & 1.758 & 0.579 & 9.127 \\
\hline 11 & 15.50 & & 2.59 & & 1.758 & 0.579 & 20.427 \\
\hline 12 & 15.50 & & 2.59 & & 1.758 & 0.579 & 20.427 \\
\hline 13 & 15.50 & & 2.59 & & 1.758 & 0.579 & 20.427 \\
\hline 14 & 15.50 & & 2.59 & 0.77 & 1.758 & 0.579 & 21.197 \\
\hline 15 & 4.20 & & 2.59 & 0.77 & 1.758 & 0.579 & 9.897 \\
\hline 16 & & & 2.59 & 0.77 & 1.758 & 0.579 & 5.697 \\
\hline 17 & & & 2.59 & & 1.758 & 0.579 & 4.927 \\
\hline 18 & & & 2.59 & & 1.758 & 0.579 & 4.927 \\
\hline 19 & & & 2.59 & & 1.758 & 0.579 & 4.927 \\
\hline 20 & & & 2.59 & & 1.758 & 0.579 & 4.927 \\
\hline 21 & & & & & 1.758 & 0.579 & 2.337 \\
\hline 22 & & 5.75 & & & 1.758 & 0.579 & 8.087 \\
\hline 23 & & 5.75 & & & 1.758 & 0.579 & 8.087 \\
\hline 24 & & & & & 1.758 & 0.579 & 2.337 \\
\hline
\end{tabular}




\section{PHOTOVOLTAIC (PV) ARRAY AND BATTERY SIZING}

General

The PV system sizing method used to determine the PV array size $\left(\mathrm{kW}_{\mathrm{pk}}\right)$ and battery capacity of the Schuchuli system was developed by LeRC and consists of four separate steps:

- Identification of load voltage sensitivities and a determination of hourly load profile for 1 day each month;

- A determination of PV cell operating temperature and the required number of series cells in an array string;

- Use of a computerized array output calculation and system simulation program which is used to determine the number of parallel PV cells in the PV array and the battery capacity; and

- Determination of the number of series battery cells required.

\section{Load Profile}

A pivotal factor in the continuous annual operation of any PV system is the battery SOC during periods of maximum load and/or minimum insolation. A typical hourly load profile for 1 day for each month thus provides the designer with a realistic basis from which to calculate battery SOC. The details of the Schuchuli load profile, as discussed above, were incorporated in the PV system sizing simulation program which is described below.

\section{Voltage Sensitivities}

Two loads imposed voltage limitations on the system design: the pump motor and the fluorescent lights inverter/ballasts. The 2-hp 120-V motor cannot be operated with voltage above $130 \mathrm{~V}$ due to speed limitations of the jack pump, and the inverter/ballasts will not start the fluorescent lights with voltage below approximately $105 \mathrm{~V}$.

Number of Series PV Cells

PV cell temperature is an important factor in PV array sizing because it affects the number of series cells required to satisfy system voltage requirements. Because cell maximum power voltage decreases with increasing temperature at the rate of approximately $2.0 \mathrm{mV} /{ }^{\circ} \mathrm{C} / \mathrm{cell}$ with a concomitant decrease in cell output power, summertime cell temperatures must be considered to avoid serious power output shortfalls during the summer months. 
The Schuchuli PV array was designed to operate near maximum power output in summer to provide enough energy to ensure battery recharge prior to the next winter season, to provide a reserve to pump more water in the event of dry periods and consequent need to water stock, and to provide a margin for higher than anticipated refrigerator operation in the hot summer months.

Cell operating temperature can be estimated from the expression:

$$
\mathrm{T}_{\text {cell }}\left({ }^{\circ} \mathrm{C}\right)=\mathrm{T}_{\text {air }}\left({ }^{\circ} \mathrm{C}\right)+0.3 \mathrm{~L}
$$

where $\mathrm{L}=$ insolation in $\mathrm{mW} / \mathrm{cm}^{2}$.

For Schuchuli, average daytime summer temperatures are at or above $35^{\circ} \mathrm{C}\left(95^{\circ} \mathrm{F}\right)$ (Table 7$)$ and average insolation was assumed to be 80 $\mathrm{mW} / \mathrm{cm}^{2}$; thus, cell operating temperature was calculated to be approximately $60^{\circ} \mathrm{C}$.

Cell maximum power voltage at $60^{\circ} \mathrm{C}$ is obtained from the expression

$$
\mathrm{V}_{\mathrm{T} 2}=\mathrm{V}_{\mathrm{T} 1}-2.0 \mathrm{mV} /{ }^{\circ} \mathrm{C} / \mathrm{cell}\left(\mathrm{T}_{2}-\mathrm{T}_{1}\right) \text {. }
$$

For the 42 series cell Solorex Model $9200 \mathrm{~J}$ module used for this project, maximum power voltage at $28^{\circ} \mathrm{C}$ is 19.15 volts based on LeRC measurements and is 16.46 volts at $60^{\circ} \mathrm{C}$.

The nominal system bus bar voltage for this system was selected as 120 $V(d . c$.$) primarily to minimize distribution line wire size and I^{2} R$ losses while at the same time providing for the use of universal motors (sewing machines) and other commercially available equipment. The number of series connected PV modules required to provide a nominal $120 \mathrm{~V}$ (d.c.) at the system bus bar was determined as eight from the following considerations:

8 series connected modules at $16.46 \mathrm{~V} /$ module $\quad 131.68$ Volts

Less: Blocking diode drop (@ 1 ampere) $\quad 0.80$

$400 \mathrm{ft}$ of No. 14 wire from array to PCCIA

(@1 ampere)

Series string current measuring resistor

$(1.0 \mathrm{ohm}$ ) @ 1 ampere 1.0

$\begin{array}{ll}\text { Miscellaneous contacts } & 0.02\end{array}$

$\overline{128.85}$ volts

\section{Description of Sizing Program}

The size of the Schuchuli PV power system, i.e., PV array peak kW and battery capacity, was determined using the LeRC computerized PV 
System Sizing Program. The program consists of two parts: a determination of the hourly current output for the selected PV cell at the selected site, and a system simulation that compares hourly PV array output with the hourly load profile to determine a running tabulation of battery SOC.

It should be noted that the LeRC sizing is carried out on an amperehour basis. Thus the ampere-hour output of a single module (or a string of series connected modules) is the same as for a single cell. The ensuing discussion, therefore, refers to single cells but should be understood in the context of a string of series connected modules. The final determination of array size in $\mathrm{kW}$ pk is therefore the product of the number of series connected modules/string, the number of parallel strings, and the peak power/ module. The cell output calculation uses site latitude and site-specific average monthly values of insolation, sky cover, atmospheric percipitable water, and atmospheric turbidity to calculate the direct and diffuse sunlight components. These data are then combined with the characteristics of a single cell (area, efficiency, and maximum power voltage) of the module selected for the application to determine cell output (ampere-hours) for each month and at several different PV array tilt angles. This matrix (see Table 8 ) is then used to identify the optimum tilt angles to input into the array output calculations in the system simulation program. The number of tilt angle changes per year is based on the amount of additional array output achieved and the availability of personnel to change the tilt angle.

An array degradation factor can be included to account for array output reduction due to dust accumulation, encapsulation darkening, cell mismatch losses, etc. And, in order to introduce random four-day weather cycle variability into the daily cell output profile, the average daily insolation value for each month can be randomly varied within defined limits every fourth day.

The system simulation program combines the hourly array output profile (cell profile times number of parallel strings) for each month with the composite hourly load profile for that month to determine battery DOD on an hourly basis.

Each sizing "run" is for a 16-month period to ensure that the initial condition of a fully charged battery does not mask any annual effects. When using randomized cell output data, the 16-month simulation is run 10 times, each time with differently randomized cell outputs, to identify the worst case DOD.

The output of the simulation program may be in either of two forms: a summary listing of system status at 0600 hours every 30 th day from start of simulation (Figure 23) or an hourly listing for every 11 th day from start of simulation (Figure 24), or both. Included with the summary listing is the value of maximum DOD in the simulation period and the run day on which it occurs. 


\section{Schuchuli Sizing}

The insolation and other atmospheric data used for the array output calculation are shown in Table 7. An array degradation factor of 20 percent was used based on LeRC soiling tests and the prevalance of dust from a nearby dirt road in the village. The randomization limits were \pm 20 percent, there not being too much variability in day-to-day weather in southwest Arizona.

Table 8 shows the cell (or series string) output as a function of tilt angle and time of year. It was determined that quarterly tilt angle changes would provide significant increase in array output without burdening local operating personnel. The tilt angles selected are: $11^{\circ}$ for the summer, $35^{\circ}$ for spring and fall, and $48^{\circ}$ for winter.

In a normal sizing operation, the designer is free to vary the size of the PV array and battery capacity to achieve his particular technical or economic design goals. The Schuchuli system sizing was somewhat constrained in that the DOE module allocation for the Schuchuli project was $3650 \mathrm{~W}$ (based on JPL maximum power rating of $18.6 \mathrm{~W} /$ module at 100 $\mathrm{mW} / \mathrm{cm}^{2}$ and $60^{\circ} \mathrm{C}$ cell temperature). In the interest of minimizing battery capacity, almost all of the allocation $(3571 \mathrm{~W})$ was used as a fixed parameter in the system sizing. The "sizing" thus reduced to calculating the appropriate size battery for a given array.

The battery cell selected for this system is from the 1.300 specific gravity lead-calcium grid lead-acid cells designed and manufactured specifically for PV systems by the C\&D Batteries Division of The Eltra Company. These cells have the advantage of low gassing resulting in low water consumption, low self-discharge, constant charge voltage over cell lifetime, large electrolyte capacity, large individual cell capacities which eliminated the need for paralleled cells and attendant charge balancing problems, and a potential cycle life of 160080 percent DOD cycles.

The inputs to the system simulation program were the composite load profile shown in Table 6 and an array size of 24 series strings of Solorex $9200 \mathrm{~J}$ modules tilted seasonally as described above. The sizing goal was to limit battery maximum DOD to 80 percent or less in the worst case situation ( $v$ is-a-vis randomization). Load shedding was not included in the system simulation which resulted in a somewhat conservative design approach.

Sizing Results

The results of the system simulation sizing indicated that, for the 3571-W PV array, 1815 ampere-hours of battery capacity are needed to keep maximum DOD to 80 percent or less.

The next larger available C\&D cell size was 1925 ampere-hours and cost $\$ 248.00$. Due to peculiarities of cell costing, the C\&D 2380-amperehour cell cost $\$ 257.00$. An added cost of $\$ 9.00$ (3.6 percent per cell) thus 
provided a 455 ampere-hour or 23.6 percent increase in cell capacity. The 2380 ampere-hour cells were therefore selected with the result that calculated maximum DOD was reduced to 61 percent, which also would tend to increase battery life.

Pilot cell capacities selected on the basis of nominal 50,10, 10, and 10 percent capacity increments of the 2380 ampere-hour cell were 1055 and 310 ampere-hours. The total pilot cell capacity is therefore 1985 amperehours, or 83 percent of the capacity of the main cells, and is distributed in $44,13,13$, and 13 percent increments.

The results of the system simulation sizing for the original design conditions, but with a 2380-ampere-hour battery, are shown in Figure 23 . Note that the maximum DOD of 61 percent occurs on run day 460 which corresponds to January 30 , based on a simulation start day of Julian day 300 (October 27). Figure 24 is an hourly listing for run days 463 and 474 from this simulation and gives the reader some insight into the hourly status shortly after maximum DOD occurs. A computer projected main battery state-of-charge annual profile is shown in Figure 25.

\section{Number of Series Battery Cells}

The number of series battery cells required is determined from such considerations as manufacturer's recommended float voltage and maximum and minimum voltage limitations of the various loads.

Battery manufacturer's recommended float voltage varies with temperature at the rate of $-5 \mathrm{mV} /{ }^{\circ} \mathrm{C} / \mathrm{cell}\left(-2.8 \mathrm{mV} /{ }^{\circ} \mathrm{F} / \mathrm{cell}\right)$, i.e., lower float voltages at higher temperatures. Battery temperatures at Schuchuli were estimated to range from $32^{\circ} \mathrm{C}\left(90^{\circ} \mathrm{F}\right)$ in summer to $4.4^{\circ} \mathrm{C}\left(40^{\circ} \mathrm{F}\right)$ in winter. Corresponding float voltages are 2.42 volts/cell at $32^{\circ} \mathrm{C}\left(90^{\circ} \mathrm{F}\right)$ and 2.56 volts/cell at $4.4^{\circ} \mathrm{C}\left(40^{\circ} \mathrm{F}\right)$.

Instantaneous system voltage for the Schuchuli system is determined by battery state-of-charge and charge or discharge current. As was shown in the system simulation, with the onset of winter and decreasing array output, the battery will gradually discharge until seasonal insolation increases to the extent that average daily array output exceeds the average daily loads. Because the battery would be in a discharged condition during winter, and, therefore, well below maximum float voltage for winter, the summer float voltage became the critical factor in determining the number of series battery cells. Thus, the number of series battery cells needed to satisfy the summertime voltage constraint was:

$$
\frac{130 \mathrm{~V} \text { (nominal maximum system voltage) }}{2.42 \mathrm{~V} / \text { cell }\left(32^{\circ} \mathrm{C}\left(90^{\circ} \mathrm{F}\right)\right. \text { float voltage) }}=53 \text { cells }
$$

System minimum voltage was determined from the discharge voltage at the 500 hour rate and at 80 percent DOD. The manufacturer's recommended value for these conditions was approximately $1.98 \mathrm{~V} /$ cell. Thus for 53 series cells, the system minimum voltage would be approximately 105 volts, the approximate minimum required to start the fluorescent lights. 
Table 7. Insolation and Weather Data*

\begin{tabular}{|c|c|c|c|c|c|c|c|c|c|c|c|c|}
\hline & Jan & Feb & Mar & Apr & May & Jun & Jul & Aug & Sep & Oct & Nov & Dec \\
\hline Ambient Temperature ${ }^{\circ} \mathrm{F}^{1}$ Max. & 65 & 70 & 75 & 85 & 90 & 100 & 100 & 100 & 95 & 85 & 75 & 65 \\
\hline Min. & 40 & 40 & 45 & 50 & 60 & 65 & 75 & 75 & 70 & 60 & 42 & 40 \\
\hline Ave. & 52 & 55 & 60 & 70 & 75 & 85 & 90 & 90 & 82 & 72 & 60 & 55 \\
\hline Mean Sky Cover ${ }^{1}$ & 0.5 & 0.4 & 0.4 & 0.3 & 0.2 & 0.2 & 0.4 & 0.3 & 0.2 & 0.3 & 0.3 & 0.4 \\
\hline Daily Insolation ${ }^{1}$ (Langleys) & 315 & 391 & 540 & 655 & 729 & 699 & 626 & 588 & 570 & 442 & 356 & 305 \\
\hline Precipitable Water ${ }^{2}(\mathrm{~cm})$ & 1.09 & 0.97 & 0.99 & 1.25 & 1.5 & 1.76 & 2.8 & 2.75 & 2.5 & 1.7 & 1.0 & 1.2 \\
\hline Atmospheric Turbidity ${ }^{3}$ & 0.05 & 0.05 & 0.06 & 0.073 & 0.073 & 0.073 & 0.08 & 0.085 & 0.08 & 0.07 & 0.065 & 0.07 \\
\hline
\end{tabular}

*Values shown are daily average values for the month.

${ }^{1}$ Climatic Atlas.

${ }^{2}$ Bulletin of the American Meteorological Society, Feb. 1960.

3 Journal of Applied Meteorology, Dec. 1969. 
Table 8. PV Cell Output, Tilt Angle vs Time of Year

Cell: SXII

NASA-Lewis Research Center Cleveland, Ohio

\section{Single String Output; Amp-Hr/Month}

\begin{tabular}{|l|r|c|c|c|c|c|c|c|c|c|c|c|}
\hline & Jan & Feb & Mar & Apr & May & Jun & Jul & Aug & Sep & Oct & Nov & Dec \\
\hline Tilt Angle: 3.5 & 163 & 183 & 273 & 318 & 364 & 339 & 316 & 300 & 283 & 229 & 179 & 157 \\
Tilt Angle: 11 & 178 & 198 & 285 & 323 & 362 & 334 & 313 & 302 & 292 & 244 & 196 & 173 \\
Tilt Angle: 18.5 & 191 & 210 & 293 & 324 & 356 & 324 & 305 & 299 & 297 & 254 & 210 & 186 \\
Tilt Angle: 26 & 201 & 218 & 297 & 319 & 343 & 309 & 293 & 292 & 297 & 261 & 221 & 196 \\
Tilt Angle: 33.5 & 208 & 223 & 296 & 311 & 327 & 290 & 276 & 281 & 293 & 265 & 228 & 203 \\
Tilt Angle: 41 & 212 & 225 & 291 & 298 & 305 & 267 & 256 & 266 & 285 & 264 & 232 & 208 \\
Tilt Angle: 48.5 & 214 & 224 & 283 & 280 & 280 & 240 & 233 & 247 & 272 & 260 & 233 & 210 \\
Tilt Angle: 56 & 212 & 219 & 270 & 259 & 251 & 211 & 207 & 224 & 256 & 251 & 231 & 208 \\
\hline
\end{tabular}




\section{Summary Listing}

\begin{tabular}{|c|c|c|c|c|c|c|c|}
\hline $\begin{array}{l}R U N \\
\text { RAY }\end{array}$ & HCUR & $\begin{array}{l}\text { YEAR } \\
\text { DAY }\end{array}$ & $\begin{array}{l}\triangle R Q A Y \\
(\triangle Y P S)\end{array}$ & $\begin{array}{l}\text { LOAD } \\
\text { (AMPS) }\end{array}$ & $\begin{array}{l}\text { DPTH } \\
\text { DSCG }\end{array}$ & SURPLUS & $\begin{array}{l}30 \text { CAY } \\
\text { SLRPLUS }\end{array}$ \\
\hline 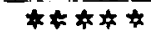 & $4 \neq \neq *$ & 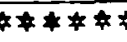 & 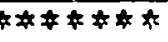 & 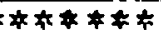 & 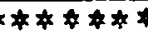 & 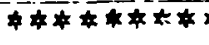 & $444464 \$ 4$ \\
\hline 1 & 6 & 330 & 3.0 & 1.18 & 0.00 & $0 . \overline{0}$ & 0.0 \\
\hline 31 & 5 & 330 & 0.0 & 0.85 & 0.11 & $c .0$ & 88.8 \\
\hline 61 & 6 & 360 & 0.0 & 0.67 & 0.27 & 0.0 & 0.0 \\
\hline 91 & $t$ & 25 & 3.0 & 0.63 & $0.4 \varepsilon$ & 0.0 & 0.0 \\
\hline 121 & 6 & 55 & 0.0 & 0.74 & 0.47 & 0.0 & 0.0 \\
\hline 151 & $\epsilon$ & 85 & 0.0 & 0.89 & 0.11 & 0.0 & 0.0 \\
\hline 181 & 6 & 115 & 2.7 & 1.10 & $0 . C 1$ & 0.0 & 1291.6 \\
\hline$-\overline{211}$ & 6 & 145 & 4.7 & 1.32 & 0.01 & $\mathrm{c} .0$ & 1959.6 \\
\hline 241 & 6 & 175 & 3.5 & 1.58 & 0.01 & 0.0 & 12.19.5 \\
\hline 271 & 5 & 205 & 4.7 & 1.76 & $C . C 1$ & 0.0 & 705.4 \\
\hline 301 & 6 & 235 & 2.3 & 1.74 & 0.12 & 0.0 & 273.1 \\
\hline 331 & 6 & 265 & 1.3 & 1.58 & $0 . c 2$ & 0.0 & 465.5 \\
\hline $36 !$ & $\bar{t}$ & 255 & 0.0 & 1.18 & 0.10 & 0.0 & 551.5 \\
\hline 391 & 6 & 325 & 0.3 & 0.85 & $0.1 E$ & $c . ?$ & $0 . \mathrm{C}$ \\
\hline 421 & 6 & 255 & 3.0 & 0.67 & 0.30 & 0.0 & 0.0 \\
\hline 451 & 6 & 20 & 0.0 & 0.63 & 0.54 & 0.0 & 0.0 \\
\hline $4 ? 1$ & S & 50 & 0.0 & 0.74 & 0.57 & 0.0 & $\bar{c} \cdot \mathrm{C}$ \\
\hline
\end{tabular}

MAXIMUM DEPTH CF DISCHAFCE = 0.61 CCCLEEC CA PIIN DAY \#4EO

Figure 23. Summary Listing for Final Sizing 


\begin{tabular}{|c|c|c|c|c|c|c|c|}
\hline $\begin{array}{l}\text { RUN } \\
\text { RAY }\end{array}$ & HCUR & $\begin{array}{l}\text { YEAP } \\
\text { DAY }\end{array}$ & $\begin{array}{l}\text { ARQAY } \\
\text { (AMPS) }\end{array}$ & $\begin{array}{l}\text { LOAD } \\
\text { (AMPSL }\end{array}$ & $\begin{array}{l}\text { DPTH } \\
\text { DSCG }\end{array}$ & SURPLUS & $\begin{array}{l}30 \text { DAY } \\
\text { SURPLUS }\end{array}$ \\
\hline \multicolumn{8}{|c|}{ 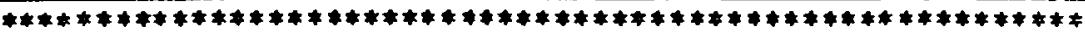 } \\
\hline $\begin{array}{l}463 \\
463 \\
\end{array}$ & $\begin{array}{l}1 \\
2 \\
\end{array}$ & $\begin{array}{l}32 \\
32 \\
\end{array}$ & $\begin{array}{l}0.0 \\
0.0 \\
\end{array}$ & $\begin{array}{l}0.74 \\
0.74 \\
\end{array}$ & $\begin{array}{l}0.6 C \\
0.6 C\end{array}$ & $\begin{array}{l}0.0 \\
0.0 \\
\end{array}$ & $\begin{array}{l}0.0 \\
0.0 \\
\end{array}$ \\
\hline $\begin{array}{l}463 \\
463 \\
\end{array}$ & $\begin{array}{l}3 \\
4\end{array}$ & $\begin{array}{l}32 \\
32 \\
\end{array}$ & $\begin{array}{l}0.0 \\
0.0\end{array}$ & $\begin{array}{l}0.74 \\
0.74 \\
\end{array}$ & $\begin{array}{l}0.60 \\
0.6 \mathrm{C}\end{array}$ & $\begin{array}{l}0.0 \\
0.0\end{array}$ & $\begin{array}{l}0.0 \\
0.0\end{array}$ \\
\hline $\begin{array}{l}463 \\
463 \\
\end{array}$ & $\begin{array}{l}5 \\
6\end{array}$ & $\begin{array}{l}32 \\
32\end{array}$ & $\begin{array}{l}0.0 \\
0.0\end{array}$ & $\begin{array}{l}0.74 \\
0.74 \\
\end{array}$ & $\begin{array}{l}0.6 \mathrm{C} \\
0.60\end{array}$ & $\begin{array}{l}0.0 \\
0.0\end{array}$ & $\begin{array}{l}0.0 \\
0.0\end{array}$ \\
\hline $\begin{array}{l}463 \\
463\end{array}$ & $\begin{array}{l}7 \\
8\end{array}$ & $\begin{array}{l}32 \\
32\end{array}$ & $\begin{array}{l}1.9 \\
6.9\end{array}$ & $\begin{array}{l}6.50 \\
3.62\end{array}$ & $\begin{array}{l}0.6 \mathrm{C} \\
0.6 \mathrm{C}\end{array}$ & $\begin{array}{l}0.0 \\
0.0\end{array}$ & $\begin{array}{ll}0 . & 0 \\
0 . & C\end{array}$ \\
\hline $\begin{array}{l}463 \\
463\end{array}$ & $\begin{array}{r}9 \\
10\end{array}$ & $\begin{array}{l}32 \\
32\end{array}$ & $\begin{array}{l}12.5 \\
17.5\end{array}$ & $\begin{array}{l}4.94 \\
4.94\end{array}$ & $\begin{array}{l}0.6 \mathrm{C} \\
0.55\end{array}$ & $\begin{array}{l}0.0 \\
0.0\end{array}$ & $\begin{array}{l}0.0 \\
\text { C. C }\end{array}$ \\
\hline $\begin{array}{l}463 \\
463\end{array}$ & $\begin{array}{l}11 \\
12\end{array}$ & $\begin{array}{l}32 \\
32\end{array}$ & $\begin{array}{l}21.4 \\
23.6\end{array}$ & $\begin{array}{r}6.90 \\
20.44\end{array}$ & $\begin{array}{l}0.55 \\
0.55\end{array}$ & $\begin{array}{l}0.0 \\
0.0\end{array}$ & $\begin{array}{l}0.0 \\
0.0\end{array}$ \\
\hline $\begin{array}{l}463 \\
463 \\
\end{array}$ & $\begin{array}{l}13 \\
14\end{array}$ & $\begin{array}{l}32 \\
32 \\
\end{array}$ & $\begin{array}{l}23.6 \\
21.4 \\
\end{array}$ & $\begin{array}{r}20.44 \\
7.70 \\
\end{array}$ & $\begin{array}{l}0.55 \\
0.58 \\
\end{array}$ & $\begin{array}{l}0.0 \\
0.0 \\
\end{array}$ & $\begin{array}{l}0 . c \\
0 . c\end{array}$ \\
\hline $\begin{array}{l}463 \\
463\end{array}$ & $\begin{array}{l}15 \\
16\end{array}$ & $\begin{array}{l}32 \\
32\end{array}$ & $\begin{array}{l}17.5 \\
12.5\end{array}$ & $\begin{array}{l}5.74 \\
5.74 \\
\end{array}$ & $\begin{array}{l}0.58 \\
0.57\end{array}$ & $\begin{array}{l}0.0 \\
0.0\end{array}$ & $\begin{array}{l}0.0 \\
0.8\end{array}$ \\
\hline $\begin{array}{l}463 \\
463 \\
\end{array}$ & $\begin{array}{l}17 \\
19\end{array}$ & $\begin{array}{l}32 \\
32 \\
\end{array}$ & $\begin{array}{l}6.9 \\
1.9 \\
\end{array}$ & $\begin{array}{l}3.34 \\
9.58 \\
\end{array}$ & $\begin{array}{l}0.57 \\
0.58\end{array}$ & $\begin{array}{l}0.0 \\
0.0\end{array}$ & $\begin{array}{l}0.0 \\
0.0 \\
\end{array}$ \\
\hline $\begin{array}{l}463 \\
463\end{array}$ & $\begin{array}{l}19 \\
20\end{array}$ & $\begin{array}{l}32 \\
32\end{array}$ & $\begin{array}{l}0.0 \\
0.0\end{array}$ & $\begin{array}{l}9.58 \\
9.58\end{array}$ & $\begin{array}{l}0.5 F \\
0.58\end{array}$ & $\begin{array}{l}0.0 \\
0.0\end{array}$ & $\begin{array}{l}0.0 \\
0.0\end{array}$ \\
\hline $\begin{array}{l}463 \\
4 t 3 \\
\end{array}$ & $\begin{array}{l}21 \\
22 \\
\end{array}$ & $\begin{array}{l}3 ? \\
3 ?\end{array}$ & $\begin{array}{l}0.0 \\
0.0\end{array}$ & $\begin{array}{l}6.50 \\
t .50 \\
\end{array}$ & $\begin{array}{l}0.55 \\
0.55\end{array}$ & $\begin{array}{l}0.0 \\
0.0\end{array}$ & $\begin{array}{l}0.0 \\
0.0\end{array}$ \\
\hline $\begin{array}{l}463 \\
46 ? \\
\end{array}$ & $\begin{array}{l}23 \\
24 \\
\end{array}$ & $\begin{array}{l}32 \\
32 \\
\end{array}$ & $\begin{array}{l}0.0 \\
0.0\end{array}$ & $\begin{array}{l}0.74 \\
0.74 \\
\end{array}$ & $\begin{array}{l}0.59 \\
0.59 \\
\end{array}$ & $\begin{array}{l}0.0 \\
0.0\end{array}$ & $\begin{array}{l}0.0 \\
0.0\end{array}$ \\
\hline $\begin{array}{l}474 \\
474 \\
\end{array}$ & $\begin{array}{l}1 \\
2\end{array}$ & $\begin{array}{l}43 \\
43 \\
\end{array}$ & $\begin{array}{l}0.0 \\
0.0\end{array}$ & $\begin{array}{l}0.74 \\
0.74\end{array}$ & $\begin{array}{l}0.57 \\
0.57\end{array}$ & $\begin{array}{l}0.0 \\
0.0\end{array}$ & $\begin{array}{l}0 . c \\
0 . C\end{array}$ \\
\hline $\begin{array}{l}474 \\
474\end{array}$ & $\begin{array}{l}3 \\
4\end{array}$ & $\begin{array}{l}43 \\
43\end{array}$ & $\begin{array}{l}0.0 \\
0.0\end{array}$ & $\begin{array}{l}0.74 \\
0.74\end{array}$ & $\begin{array}{l}0.57 \\
0.57\end{array}$ & $\begin{array}{l}0.0 \\
0.0\end{array}$ & $\begin{array}{l}0.0 \\
0.0\end{array}$ \\
\hline $\begin{array}{l}474 \\
474\end{array}$ & $\begin{array}{l}5 \\
6\end{array}$ & $\begin{array}{l}43 \\
43\end{array}$ & $\begin{array}{l}0.0 \\
0.0\end{array}$ & $\begin{array}{l}0.74 \\
0.74\end{array}$ & $\begin{array}{l}0.57 \\
0.57\end{array}$ & $\begin{array}{l}0.0 \\
0.0\end{array}$ & $\begin{array}{l}0.0 \\
0.0\end{array}$ \\
\hline $\begin{array}{r}474 \\
474\end{array}$ & $\begin{array}{l}7 \\
8 \\
\end{array}$ & $\begin{array}{l}43 \\
43 \\
\end{array}$ & $\begin{array}{l}1.5 \\
5.3\end{array}$ & $\begin{array}{l}6.50 \\
3.62 \\
\end{array}$ & $\begin{array}{l}0.57 \\
0.57\end{array}$ & $\begin{array}{l}0.0 \\
0.0\end{array}$ & $\begin{array}{l}\text { C. C } \\
0.0\end{array}$ \\
\hline $47 \overline{4}$ & 9 & 43 & 9.7 & 4.94 & 0.57 & $0 . \overline{0}$ & 0.0 \\
\hline 474 & 10 & 43 & 13.5 & 4.94 & 0.57 & 0.0 & 0.0 \\
\hline 474 & 11 & 43 & 16.5 & 6.90 & 0.56 & 0.0 & 0.0 \\
\hline 474 & 12 & 43 & 18.2 & 20.44 & 0.56 & 0.0 & 0.0 \\
\hline $\begin{array}{l}474 \\
474\end{array}$ & $\begin{array}{l}13 \\
14 \\
\end{array}$ & $\begin{array}{l}43 \\
43 \\
\end{array}$ & $\begin{array}{l}18.2 \\
16.5 \\
\end{array}$ & $\begin{array}{r}20.44 \\
7.70 \\
\end{array}$ & $\begin{array}{l}0.57 \\
0.5 t\end{array}$ & $\begin{array}{l}0 . ? \\
0.0\end{array}$ & $\begin{array}{l}0.0 \\
0.0\end{array}$ \\
\hline 474 & 15 & 43 & 13.5 & 5.74 & 0.56 & c. 0 & 0.0 \\
\hline 474 & $1 t$ & 43 & 9.7 & 5.74 & 0.56 & 0.0 & 0.0 \\
\hline $\begin{array}{l}474 \\
474\end{array}$ & $\begin{array}{l}17 \\
19\end{array}$ & $\begin{array}{l}43 \\
43\end{array}$ & $\begin{array}{l}5.3 \\
1.5\end{array}$ & $\begin{array}{l}3.34 \\
9.58\end{array}$ & $\begin{array}{l}0.5 t \\
0.5 t\end{array}$ & $\begin{array}{l}0.0 \\
0.0\end{array}$ & $\begin{array}{l}0.0 \\
0.0\end{array}$ \\
\hline 474 & 19 & 43 & 0.0 & 9.58 & $0.5 t$ & 0.0 & 0.0 \\
\hline 474 & 20 & 43 & 0.0 & 9.59 & 0.57 & 0.0 & 0.0 \\
\hline 474 & 21 & 43 & 0.0 & 6.50 & 0.57 & 0.0 & 0.0 \\
\hline 474 & 22 & 43 & 0.0 & 6.50 & 0.57 & 0.0 & 0.0 \\
\hline 474 & 23 & 43 & 0.0 & 0.74 & 0.57 & 0.0 & 0.0 \\
\hline 474 & 24 & 43 & 0.0 & 0.74 & 0.57 & 0.7 & 0.0 \\
\hline
\end{tabular}

Figure 24. Hourly Listing for Run Days 463 and 474 


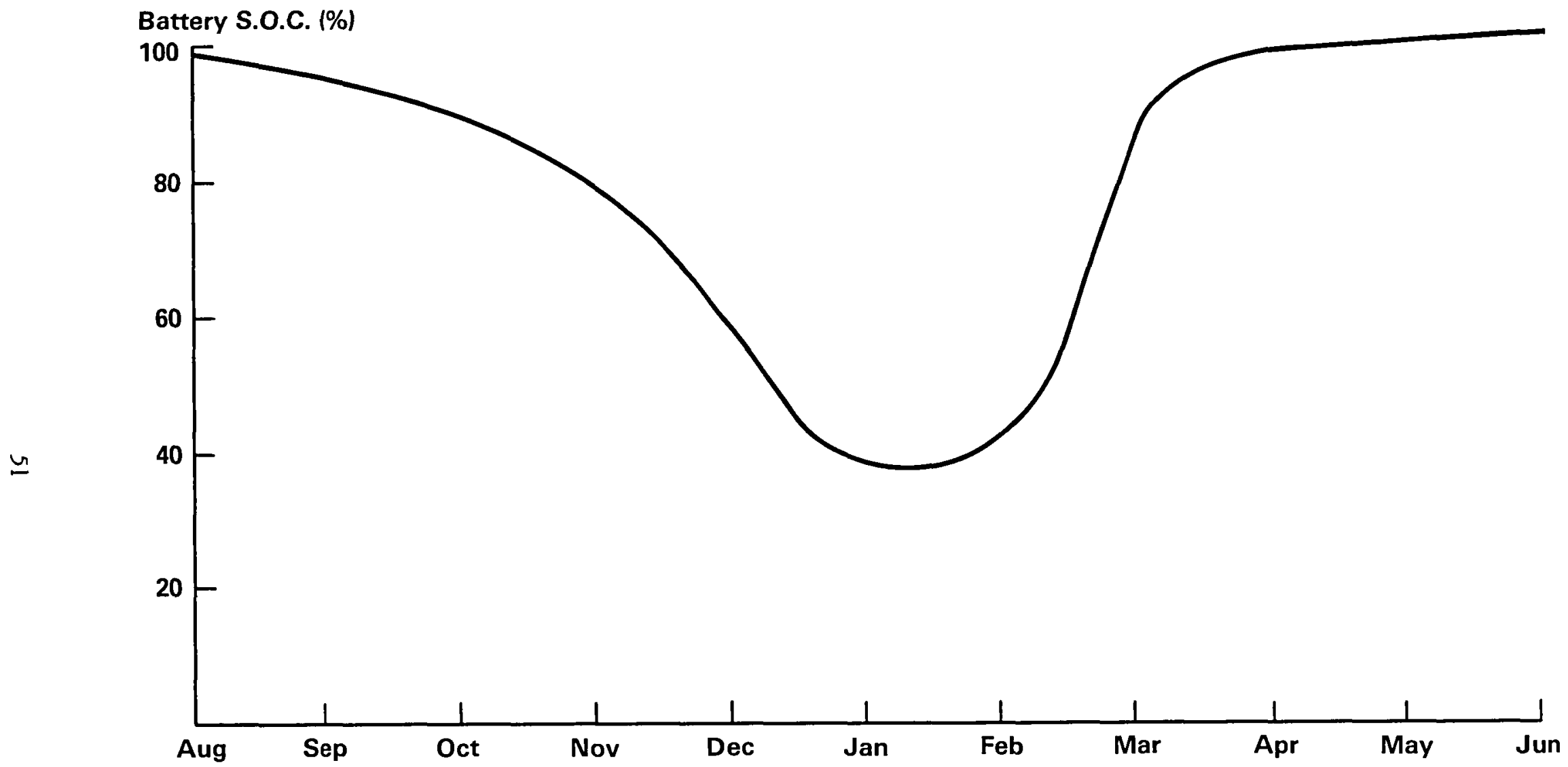

Figure 25. Computer Projected Battery State of Charge Profile 


\section{MECHANICAL DESIGNS}

Site Layout

The village is about $1 / 4$ mile south of State Route 86 and consists of 18 homes, a church, feast house, miscellaneous sheds, and a large corral. The village site and location plan is shown in Appendix A, Drawing No. CF 56376, which also shows locations of the pumps, the water and electrical distribution systems, the PV array, the EEB, and the DSB.

The EEB and PV array are located near the western edge of the village adjacent to the existing new drilled well. This location provides several advantages. It is reasonably removed and isolated from the normal village activities, thereby minimizing accumulation of dust and dirt on the arrays. It is close to the existing well and pump and thus forms the village utility system area.

The DSB is located in the southeast portion of the village, near the other existing community buildings--the church and feast house. This location was selected by the villagers.

The water distribution system was already in place around the village. The power line and poles were located by the PTUA in the general vicinity of the water line to establish a utility corridor around the village.

\section{Array}

The array consists of 24 panels arranged in 3 rows of 8 panels each. The array area is bounded by a $6-\mathrm{ft}$ commercial grade chain link fence, topped with 3 strands of barbed wire. Access to the area is gained through a 12-ft double swing vehicular gate at the southwest corner of the area. The gate is kept locked for security reasons.

The array structure is shown in Appendix A, Drawing No. CF 56378. The panel frames and supporting structure are designed to resist the aerodynamic loads from a $100-\mathrm{mph}$ wind in any of the positions of tilt for the array panels. These structures are made up of pre-formed "superstrut" components with bolted fabrication. The panels and structure were assembled in Cleveland, Ohio, by a NASA LeRC contractor. This design was employed to minimize the on-site fabrication and assembly time and to eliminate the need for specialized work skills at Schuchuli. The design permits manual setting of the panel tilt angle to any of 3 settings; i.e., 110, 350, and $48^{\circ}$ from the horizontal. As noted on the drawing, the height of the support posts are stepped, south to north, at $3 \mathrm{ft} 9 \mathrm{in.,} 4 \mathrm{ft} 3 \mathrm{in.}$, and $4 \mathrm{ft} 9 \mathrm{in}$. to reduce the spacing between rows while eliminating shadowing with low sun angles. The design was kept simple and direct to facilitate ease of construction and maintenance including the quarterly resetting of tilt angle and the possibility of panel replacement. 


\section{Buildings}

Two buildings were constructed to house elements of the power system: the Electrical Equipment Building and the Domestic Services Building. Both buildings have one story and are of standard block wall and concrete slab floor construction. Both buildings contain insulation in the wall block cores and the ceiling and have turbine ventilators on the roof to aid ventilation.

The EEB architectural plans, elevations, and details are shown in Appendix A, Drawing No. CF 56377. This building contains two rooms, one for electrical equipment and storage and the other for batteries. The electrical equipment room contains the PCCIA, main circuit breaker panel, pump motor starter, DAT-3, EWS recorder and battery, and a storage cabinet. The battery room contains the 120-volt and 12-volt batteries, fused switches, disconnects, and an emergency eyewash and shower.

The DSB, except for electrical wiring, was provided by the PTA and constructed to the same general specifications as the EEB. The building layout is shown in Appendix A, Drawing No. 56379. The DSB contains the 15 refrigerator/freezer units, a washing machine and tubs, a sewing machine, two ceiling lights, a control panel for effecting load mangement functions, and a circuit breaker panel. A solar thermal hot water heater is located on the roof to supply hot water for the laundry. 


\section{ELECTRICAL DESIGNS}

\section{General}

The electrical system has been described in the section on system description and the individual sections covering the array, battery, and instrumentation and control. The electrical system is shown diagrammatically in Figure 7 and the system drawings and schematics are contained in Appendix A, Drawings No. CF 56379 through CF 56382. The Electrical One Line Diagram (Drawing CF 56380) shows the basic electrical system. Power from the array and battery is distributed to the loads through a 40-ampere main load shunt trip circuit breaker located in Power Panel Pl. Five major load buses emanate from $\mathrm{Pl}$ and each is protected by a circuit breaker. The load bus to the DSB is protected by two circuit breakers, one in the EEB and the other in the DSB. The circuit breaker in the DSB provides for additional personnel safety in the DSB which is located 1500 feet from the EEB.

\section{Array}

The 192 Solarex model 9200J PV modules in the PV array are arranged in 24 panels of 8 modules each. The 8 modules in each panel are connected in series to form a nominal 120-volt string. The details of the panel wire harness are shown on Drawing CF 56380. Power from each panel is routed to a junction box at the end of each row and then cabled underground into the PCCIA in the EEB. Note that there is a disconnect plug in the center of each harness in addition to the disconnect plug which connects the panel to the system cabling. When both plugs are disconnected, the array panel is segmented into four groups of two series connected modules. The maximum open circuit voltage of a panel is thus reduced to less than 50 volts, the commonly accepted minimum lethal d.c. voltage.

The complete circuit for each array panel is shown in lines 1 through 47 of Drawing CF 56381. Except for the panels, all of the other array circuit elements are in the PCCIA. The fuses are included to protect circuitry from lightning-induced surges. The physical orientation of the fuse switch is designed for safety purposes to de-energize the exposed contact when the array strings are removed from the system bus and when $\mathrm{CBl}$ is open. The diodes serve to prevent battery discharge through the strings at night. The relay contacts are the solid-state relays (SSR) used for array string switching in conjunction with system voltage control. The $1.0-\mathrm{ohm}$ resistor in each string is used in conjunction with the panel meter and DAT-3 to monitor individual string currents.

The total array output is carried by the 40-ampere circuit breaker CB1 (lines 51 through 55, Drawing CF 56381). CBI is a shunt trip circuit breaker and can be actuated in three ways: (1) manually when being used to disconnect the array during maintenance operations in the PCCIA, (2) automatically in conjunction with over-voltage conditions (see controls discussion), and (3) remotely by the system emergency OFF switch (lines 72, and 246, Drawings CF 56381 and CF 56382). The Neon glow lamp (line 
53) across $\mathrm{CB} 1$ is intended as an operator alarm of a system problem, as is the audible alarm (line 171, Drawing CF 56381).

The array is protected from lightning by an extensive grounding circuit. The frame of each module is connected to a separate ground harness (Drawing CF 56380), which is attached to the array panel frame and support structure. The support structures are in turn connected to a No. 4/0 ground wire buried about 15 inches below grade (Drawing CF 56379). The array field fence and the Climatronics weather station tower are also attached to the ground wire. The fence gives added lightning protection to the array field. There are six 1 -in. by $10-\mathrm{ft}$ grounding rods located on the periphery of the ground system. In addition, the ground wire is connected to the well casing which also serves as the ground point for the EEB. All connections to the No. 4/0 ground wire, as well as splices in the wire system, are thermite welds.

Batteries

The main battery consists of the 52 C\&D model LCPSA-19 cells rated at 2380 ampere-hours and 4 pilot cells; 1 C\&D modell KCPSA-15 rated at 1055 ampere-hours, and 3 C\&D model DCPSA-15 cells each rated at 310 ampere-hours. The $522380 \mathrm{~A}-\mathrm{H}$ cells are connected in series. The four pilot cells are connected in parallel to form the 53rd cell in the series string. The cells and other associated circuit components are shown in lines 72 through 99 of Drawing CF 57381 and Elevation D of Drawing CF 56379.

The battery is isolated by a circuit breaker and several fused disconnects. Circuit breaker CB13 is a shunt trip circuit breaker which is actuated by the system emergency OFF switch S1OB. CB13a and CB13b are used to disconnect the main and I/C batteries, respectively. Fuse switch S7 contains a 40-ampere fuse. Switches S7, S7A, and S7B are designed to sectionalize the battery into four series strings (three 32-volt strings and one 17-volt string) to provide personnel safety during maintenance operations. Switch S7C isolates the pilot cells.

The voltage regulation control meter relay (V1) is connected to the positive battery bus at the battery so as to minimize line drops and their subsequent effect on the battery control. Meter relays V4, V5, V6, and V7 and relay contacts CR27, CR29, CR31, and CR33 are used as part of the load management system and are described below.

The I/C battery consists of six C\&D model KCPSA-15 cells rated at 1055 ampere-hours as shown in Elevation D of Drawing CF 56379 and on Line 217 of Drawing CF 56382. This battery is kept charged by a $120-\mathrm{V}$ (d.c.) to $12-\mathrm{V}$ (d.c.) converter and is protected by circuit breakers $\mathrm{CB} 13$ and CB11 (lines 217 through 222, Drawing CF 56382). CB13b is one set of contacts of the shunt trip circuit breaker actuated by the emergency OFF switch S10B. 
There are two thermistors associated with the batteries. One senses battery room air temperature approximately 5 feet above the floor, and the other is inserted in the electrolyte in one of the main battery 2380-amperehour cells located in the top tier of the battery rack.

\section{Controls}

An electromechanical system voltage and load management control system was selected for Schuchuli because it can be understood and maintained by technicians familiar with electric utility systems. The control system consists of meter relays that sense system voltage and current parameters and feed control signals to a programmable drum relay, or drum programmer (DP). The DP in turn drives electromechanical and solid-state relays which control system functions. Table 9 lists the major control subsystem elements and their functions.

To understand the control subsystem, the reader must understand the way the DP interfaces with the other control system elements. Figure 26 is a reproduction and elaboration of the Drum Programmer Schedule shown in Drawing CF 56382. Rather than describe in detail each of the various control circuits (most of which are understandable by readers familiar with electromechanical controls), only those aspects or features of the controls which cannot be readily understood from the schematics are described below. For these descriptions, line number references will be to the electrical schematics of Drawings CF 56381 and CF 56382.

1. The meter relay contacts are in the "normal" position when the value of the parameter being sensed is between the high and low limit settings and when 12-volt power is applied to the meter relay.

2. Whenever possible, control relays were designed to function in the unenergized mode so as to conserve energy. However, relays in safetyrelated circuits operate normally in the energized mode so as to fail safe in the event of loss of power.

3. The control system incorporates an over- and an under-voltage protection feature which protects the system in the event the normal controls fail. Over-voltage protection prevents damage to controls, battery, and loads. Under-voltage protection prevents excessive battery discharge. The over- and under-voltage protection circuits use normally energized relays CR41 and CR42 and meter relay Vla to actuate circuit breakers CBI and CB2. Vla (Hi) contacts de-energize CR41 which trips CB1, disconnecting the PV array from the main bus. Vla (Lo) contacts de-energize CR42 which trips $\mathrm{CB} 2$ and disconnects all 120 -volt loads.

4. The DP uses a $120-\mathrm{V}, 60-\mathrm{Hz}$ stepping motor and stepping interval timer. The inverter which inverts $12 \mathrm{~V}\left(\mathrm{~d} . \mathrm{cc}_{\text {.) }}\right.$ to $120 \mathrm{~V}$ (a.c.) (Line 310) requires a regulated $12-\mathrm{V}$ input in order to provide a $117-$ to $120-\mathrm{V}$ (a.c.) output to the stepping motor and the stepping timer (CA timer, line 312). Because the $120-\mathrm{V}$ (d.c.) to $12-\mathrm{V}$ (d.c.) converter outputs 13.6 volts to keep 
the I/C battery charged, a 12-V regulator (lines 307 and 308) was required to provide 12 volts to the input of the inverter.

5. Because of the number of switches and relay closures associated with DP stepping, it is possible that before the stepping process is completed, the actuating device (i.e., V1, V4, V5, V6, V7, or A15) may open its contact. This would de-energize stepping motor control relays CR50 or CR51 (lines 290 and 304, and 311 and 312) and remove the 12-V power to the DP in mid-step. Relay CRAC (lines 309 and 311) ensures that power is applied to the DP until the stepping process is completed.

6. Referring to lines 292 and 303 , note that V1 (Hi) can drive the DP "up" when the system is operating under pilot cell control. This bypass or override feature is necessary because there are combinations of high battery charge current, moderate to high main battery state-of-charge and moderate to low pilot cell states-of-charge which can result in system (V1) voltages in excess of 130 volts while pilot cell voltage can be less than the V4, V5, V6, or V7 ( $\mathrm{Hi}$ ) settings. This situation is most likely to occur when pilot cell No. 1 is connected to the main battery because, for a given main cell state-of-charge, a discharged or discharging pilot cell may have a substantially lower state-of-charge than the main (2380-ampere-hour) cells. For very high array charging currents, it is thus possible for the 52 main cells to be driven to or above float voltage while the same current charging a more deeply discharged single pilot cell drives it to something less than its float voltage. Under these conditions, system voltage can exceed V1 ( $\mathrm{Hi}$ ) $(130 \mathrm{~V})$ and reach the system over-voltage limit $(\mathrm{V} 1 \mathrm{~A}(\mathrm{Hi})=138$ volts $)$ and cause CBI (PV array circuit breaker) to be tripped. By providing the option for V1 ( $\mathrm{Hi}$ ) control when in pilot cell control, system voltages above 130 volts $(\mathrm{V} 1(\mathrm{Hi}))$ can be avoided by progressively switching to the next higher pilot cell until all pilot cells are paralleled, and array string switching can occur.

7. When the DP is in position 1, a special step-up logic and an additional relay $(C R 43)$ is required to prevent the DP from stepping directly from position 1 to position 3 without remaining in position 2 . The DP is stepped from position 2 to position 1 by V7 (Lo) N.O. contact (line 295) when the V7 voltage drops below the V7 (Lo) limit. In position 1, the refrigerator/freezer circuit is turned off by CR37 (line 276), and CR43 (line 278 ) is energized. When the V7 voltage goes above the V7 (Lo) limit and A15 is greater than 6 amperes, the DP is stepped from position 1 to position 2 by the V7 (LO) N.C. contact, the CR43 N.O. contact (line 302), and the A15 (Hi) contact (line 303). In position 2, CR43 is de-energized, and the refrigerator/freezer circuit is turned on. The DP is stepped from position 2 to position 3 by the V7 (Hi) N.O. contact (line 301), the CR43 N.C. contact (line 301), and the A15 (Hi) contact.

8. The water pump motor controls are shown in two places. The power circuit to the pump motor is shown in lines 100 to 105 , and the controls circuits are shown in lines 277 to 286. From a system efficiency and cost standpoint, it is better to store water than to store energy. The pump motor controls are therefore designed to allow normal pump operation 
only during daylight hours, or more specifically, only when the PV array is generating more than 3 amperes. The control logic is arranged such that when the array output is $\geq 3$ amperes, the pump will come on when the water level in the water storage tank has dropped about 18 inches below the full level. Once turned on, the pump will operate until the tank is full. In the event of heavy water use at night, the pump will come on when the tank is approximately half full and continue to pump until the tank is full.

Referring to lines 275 to 286, there are four elements involved in pump motor operation: adjustable pressure switches (PS1, PS2, and PS3) located near the bottom of the water storage tank that sense various water levels; the high limit contacts of Al acting through CR39; DP switch 26 acting through CR25; and load management status control acting through DP29 and CR 36.

When the water level in the tank drops about 18 inches below the full level, PS2 closes to provide power to the motor starter through relay contacts CR39 and/or CR25. The CR39 contacts are closed when array current exceeds the $\mathrm{Al}$ ( $\mathrm{Hi}$ ) setting of 3 amperes. This restriction is intended to minimize pilot cell discharge when the system is under pilot cell control (DP position 5 or 4 ) by deferring pump operation until array output reaches a significant portion ( 3 amperes) of the average pump load ( 7 amperes). The CR25 contacts, which are closed when the system is in V1 control (i.e., DP positions 6 through 24 and all pilot cells connected in parallel and normally charged), allow pump operation to be independent of array output.

When PS2 closes and either CR39 or CR25 is closed, power is applied to the start (S)relay and to the 3-second timer (TR, line 282) of the 2-step pump motor starter. A 2-step motor starter is used for the 2-hp permanent magnet motor to avoid high starting currents and possible demagnetization. Starting voltage is applied to the motor through (S) contacts in series with a starting resistor (line 102). After 3 seconds, timer contacts TR close applying power to run relay (R) which: (1) de-energizes starter relay (S) which disconnects the starter resistor, (2) applies line voltage to the motor (line 104), and (3) causes (B) to latch itself in through its (R) contacts in series with its coil (line 283) and its RUN (B) contacts in series with PS1 (line 284) which contacts are closed when the water level is below full. When the tank is full, PS 1 opens de-energizing (B) which opens the $(B)$ contact in series with the motor (line 104).

PS3 closes when the tank level falls below half full and causes the pump to operate regardless of array output until the tank is full. The pump will not come on at all when the main battery is discharged beyond approximately 70 percent DOD and the system switches to pilot cell No. 4 control (DP position 2 or 1 ).

The lights L1, L2, L3, and L4 (lines 281, 283, and 285) are located in the PCCIA to indicate the status of the level switches which are located at the water tank which is approximately $1500 \mathrm{ft}$ from the PCCIA. Although the pump normally operates in an automatic mode, it can be 
operated manually, regardless of the water level, by means of the Auto/ Hand switch (lines 280 and 281). The pump may be stopped at any time by (1) pushing the EMERGENCY STOP push button switch (line 280) or (2) switching the Auto/Hand switch to the OFF position.

9. Terminals $T 5-83,84,87,88$ (lines 305 and 306) are included in the DP for an external controller to control the DP position. This control is enabled by switching $S 9$ from the LOCAL to the DAT-3 positions. This provision was incorporated because the $\overline{\mathrm{DA}} \mathrm{T}-3$ contains microprocessor circuits which could be used to control the system at some later time. To use the DAT-3 for control would, however, require additional programming of the DAT-3 and would also eliminate the separation of the DAT-3 data recovery function from the system control function thus running the risk of losing both control and monitoring capacity should certain parts in the DAT3 fail.

$\underline{\text { Instrumentation }}$

The bulk of the instrumentation is for diagnostic purposes for this experimental system and would not be required for the operation of a similar system. The instrumentation consists of 17 ammeters, 17 ampere-hour meters, 8 voltmeters, 8 runtime meters, 2 water meters, a sample temperature sensor at the center of the array, the DAT-3 automatic data recorder, and the self-contained EWS as previously described. Figure 27 illustrates the instrumentation layout, and Table 10 defines their functions and ranges (See Drawings CF 56381 and 56382).

Instrumentation for individual PV array strings consists of a voltmeter V2 (Drawing CF 56381, line 55) to indicate the string voltages and a millivoltmeter MV1 (Drawing CF 56381, line 55) to indicate the string currents. A two-deck, 28-position switch, SS1 in Row 2, is used to select individual array string voltages and currents. A momentary push button switch, S6 in Row 2, is used to check the string short circuit current for the individual strings.

Ampere-hour meters AH3 through AH7 and AH15 are dual ampere-hour meters. One section measures the ampere-hours of charge the battery or cell receives. The other section measures the ampere-hours of discharge supplied by the battery or cell.

$\mathrm{A} 1, \mathrm{~A} 15, \mathrm{~V} 1, \mathrm{~V} 1 \mathrm{a}$, and $\mathrm{V} 4$ through $\mathrm{V7}$ are meter relays which have two set points and are used to initiate control action. The normally open (N.O.) and normally closed (N.C.) convention used in Drawings CR 56381 and CF 56382 for the meter relays are reversed compared to the meter relay manufacturer's information. The manufacturer's convention is the position of the relay contacts when the meter relay is de-energized whereas the convention used in the drawings is with the meter relay energized and the meter reading between the two set points.

A thermistor signal conditioner, THC (Drawing CF 56381, line 170) includes bridges and amplifiers that are used to condition the thermistor signals. Temperature measurements include: (1) PV module in the array, 
(2) main battery electrolyte, (3) pump motor, (4) a sample refrigerator,

(5) a sample freezer, and (6) ambient air in the battery room.

The temperature readout meter in Row 10 of Figure 27 and the refrigerator compressor current meter in Row 13 of Figure 27 each uses six position selector switches for selecting individual parameter readouts.

The I/C system measurements are for voltage (V3), current (A3), and ampere-hours (AH3). The $120-\mathrm{V}$ power for the $\mathrm{I} / \mathrm{C}$ system is measured by the AH16 ampere-hour meter.

The DAT-3 automatic data recorder monitors the parameters shown in Figure 11. It uses the same sensors as the panel meters; the connections are marked T-5 on the drawings (CF 56381 line 49 and CF 56382 line 305). Measurements are automatically taken every 20 seconds and recorded on cassette tape once an hour on the hour. The average maximum and/or minimum value for the preceding hour and/or the instantaneous value on the hour may be selected for recording by a software program in the DAT-3. The tapes are changed once a week and sent to LeRC for computer reduction of the data. The type data taken at each test point are shown in the column labeled "Data Type" of Figure 11.

\section{Distribution}

The distribution system consists of overhead wires carried on wooden poles provided by the PTUA as shown on Drawings CF 56376 and 56379. This system consists of two circuits of two wires each--a two-wire system provides power from the EEB to the DSB (to panel No. 2) and the two-wire village light system loop which serves the homes, church, and feast house including the drops to each building. It should be noted that the $\mathrm{I} / \mathrm{C}$ cabling to the DSB is carreid on the distribution poles. A fifth (topmost) wire on the distribution poles is a grounding wire for lightning protection.

\section{Cabling}

The cabling from the array to the EEB is buried underground in galvanized conduit (Drawing CF 56379). All other cabling is carried in galvanized conduit and, where external to the buildings, is underground (i.e., EEB to pump motor). 
Table 9. Control System Elements and Their Functions

\begin{tabular}{|c|c|}
\hline Element and Location & Function \\
\hline $\begin{array}{l}\text { Drum Programmer } \\
\text { DP (lines 290-304) }\end{array}$ & $\begin{array}{l}\text { Part of the Electromechanical Logic System } \\
\text { Under Control of Various Meter Relays Which: } \\
\text { (1) Switches PV Array Strings On and Off for } \\
\text { System Voltage Control. } \\
\text { (2) Switches Individual Pilot Cells In and Out } \\
\text { When in Main Battery Discharge Mode. } \\
\text { (3) Disconnects and Reconnects Load } \\
\text { Circuits When Load Management Is Being } \\
\text { Effected in Response to >50\% DOD of } \\
\text { Main Battery Cells. }\end{array}$ \\
\hline
\end{tabular}

V1 (Meter-Relay, Line 72)

"System Voltage Regulation"

- Displays System Voltage Sensed at Main Battery Terminal.

- High Limit (130V)-Initiates Array String Disconnect:

(1) Reduce Array Output

(2) Reduce System Voltage

- Low Limit (125V) - Initiates Array String Reconnect:

(1) Increase Array Output

(2) Increase System Voltage

(3) After All Strings Are Reconnected and V System <125V, Drives DP to Pilot Cell Control Mode.

V1A (Meter-Relay Line 57)

"System Voltage Protection"
- Displays System Voltage Sensed at System Bus.

- High Limit ( $\geq 138 \mathrm{~V}$ ) - Over Voltage Condition Actuates CBI to Disconnect PV Array

- Lo Limit ( $\leq 100 \mathrm{~V}$ ) - Under Voltage Condition Actuates CB2 to Disconnect All 120V Loads.

- Display Total Array Current

- High Limit ( $\geq 3$ amperes)-Enables Pump Operation When in Pilot Cell Control Mode.

- Displays Main Battery Charge and Discharge Current

- High Limit (6 amperes)-Restricts DP Switching From a Charged Pilot Cell to a Discharged Pilot Cell During Battery Recovery Sequencing (e.g., From DP Position 4 to 5), Until There Is Sufficient Charge Current to Maintain the 
Table 9. Control System Elements and Their Functions (continued)

\begin{tabular}{|c|c|}
\hline Element and Location & Function \\
\hline & $\begin{array}{l}\text { Discharged Pilot Cell Voltage Above Its Low } \\
\text { Limit Setting (i.e., V4, V5, V6 and V7 (Lo)) so } \\
\text { as to Prevent Oscillations Between Charged } \\
\text { and Discharged Pilot Cells. } \\
\text { - Lo Limit (2 amperes) - Restricts DP Switching } \\
\text { From V1 Control to Pilot Cell Control (i.e., DP } \\
\text { Position } 6 \text { to 5) to Periods of Low or No Battery } \\
\text { Charge Current to Prevent Control System } \\
\text { Oscillation Between DP Positions } 6 \text { and } 5 .\end{array}$ \\
\hline $\begin{array}{l}\text { V4 (Meter-Relay, Line 73(CF-1) } \\
\text { "Pilot Cell No. } 1 \text { Control" }\end{array}$ & $\begin{array}{l}\text { - Indicates Terminal Voltage of Pilot Cell No. } 1 . \\
\text { - Low Limit (1.95V)-During Discharge of Pilot } \\
\text { Cell No. 1, Low Limit Indicates End-of-Discharge } \\
\text { for Pilot Cell No. } 1 \text { (Approximately 50\% DOD of } \\
\text { Main Battery) and Commands the DP to Step } \\
\text { From Position } 5 \text { (No. } 1 \text { Pilot Cell Control) to } \\
\text { Position } 4 \text { (No. } 2 \text { Pilot Cell Control) and to } \\
\text { Disconnect the Washing and Sewing Machine } \\
\text { Circuit. } \\
\text { - High Limit (2.45V)-During Re-Charge of Pilot } \\
\text { Cell No. 1, High Limit Indicates Pilot Cell No. } 1 \\
\text { Is Approximately Fully Charged and Commands } \\
\text { DP to Step From Position } 5 \text { (No. } 1 \text { Pilot Cell } \\
\text { Control) to Position } 6 \text { (V1 Control and All Pilot } \\
\text { Cells Connected in Parallel). }\end{array}$ \\
\hline $\begin{array}{l}\text { V5 (Meter-Relay, Line 78) } \\
\text { "Pilot Cell No. } 2 \text { Control" }\end{array}$ & $\begin{array}{l}\text { - Indicates Terminal Voltage of Pilot Cell No. } 2 \\
\text { - Low Limit (1.95V)-Indicates End-of-Discharge } \\
\text { for Pilot Cell No. } 2 \text { (Approximately } 60 \% \text { DOD of } \\
\text { Main Battery) and Commands the DP to Step } \\
\text { From Position } 4 \text { (No. } 2 \text { Pilot Cell Control) to } \\
\text { Position } 3 \text { (No. } 3 \text { Pilot Cell Control) and to } \\
\text { Disconnect the Village Lights Circuit. } \\
\text { - High Limit (2.45V)-During Re-Charge of Pilot } \\
\text { Cell No. 2, High Limit Indicates Pilot Cell No. } 2 \text { Is } \\
\text { Approximately Fully Charged and Commands } \\
\text { DP to Step From Position } 4 \text { (No. } 2 \text { Pilot Cell } \\
\text { Control) to Positions } 5 \text { (No. } 1 \text { Pilot Cell Control), } \\
\text { and to Reconnect the Washing and Sewing } \\
\text { Machine Circuit. }\end{array}$ \\
\hline $\begin{array}{l}\text { V6 (Meter-Relay, Line 84) } \\
\text { "Pilot Cell No. } 3 \text { Control" }\end{array}$ & $\begin{array}{l}\text { - Indicates Terminal Voltage of Pilot Cell No. } 3 \\
\text { - Low Limit (1.95V) - Indicates End-of-Discharge }\end{array}$ \\
\hline
\end{tabular}


Table 9. Control System Elements and Their Functions (continued)

\begin{tabular}{|c|c|}
\hline Element and Location & Function \\
\hline & $\begin{array}{l}\text { for Pilot Cell No. } 3 \text { (Approximately } 70 \% \text { DOD of } \\
\text { Main Battery) and Commands the DP to Step } \\
\text { From Position } 3 \text { (No. } 3 \text { Pilot Cell Control) to } \\
\text { Position } 2 \text { (No. } 4 \text { Pilot Cell Control) and to } \\
\text { Disconnect the Water Pump Motor Circuit. } \\
\text { - High Limit (2.45V)-During Re-Charge of Pilot } \\
\text { Cell No. 3, High Limit Indicates Pilot Cell No. } 3 \text { Is } \\
\text { Approximately Fully Charged and Commands } \\
\text { DP to Step From Position } 3 \text { (No. } 3 \text { Pilot Cell } \\
\text { Control) to Position } 4 \text { (No. } 2 \text { Pilot Cell Control) } \\
\text { and to Reconnect the Village Lights Circuit. }\end{array}$ \\
\hline $\begin{array}{l}\text { V7 (Meter-Relay, Line 90) } \\
\text { "Pilot Cell No. } 4 \text { Control" }\end{array}$ & $\begin{array}{l}\text { - Indicates Terminal Voltage of Pilot Cell No. } 4 \\
\text { - Low Limit (1.95V) } \\
\text { (1) Indicates End-of-Discharge for Pilot Cell } \\
\text { No. } 4 \text { (Approximately } 80 \% \text { DOD of Main } \\
\text { Battery) and Commands the DP to Step } \\
\text { From Position } 2 \text { (No. } 4 \text { Pilot Cell Control) } \\
\text { to Position } 1 \text { Maintaining Pilot Cell No. } 4 \\
\text { Control But Disconnecting the Refrigerator/ } \\
\text { Freezer Circuit. } \\
\text { (2) Senses Battery Re-Charge (>1.95V) and } \\
\text { Commands DP to Step From Position } 1 \\
\text { to Position } 2 \text { and Reconnects the } \\
\text { Refrigerator/Freezer Circuit. } \\
\text { - High Limit (2.45V)-During Re-Charge of Pilot } \\
\text { Cell No. 4, High Limit Indicates Pilot Cell No. } 4 \text { Is } \\
\text { Approximately Fully Charged and Commands } \\
\text { DP to Step From Position } 2 \text { (No. } 4 \text { Pilot Cell } \\
\text { Control) to Position } 3 \text { (No. } 3 \text { Pilot Cell Control) and } \\
\text { to Reconnect the Water Pump Motor Circuit. }\end{array}$ \\
\hline
\end{tabular}




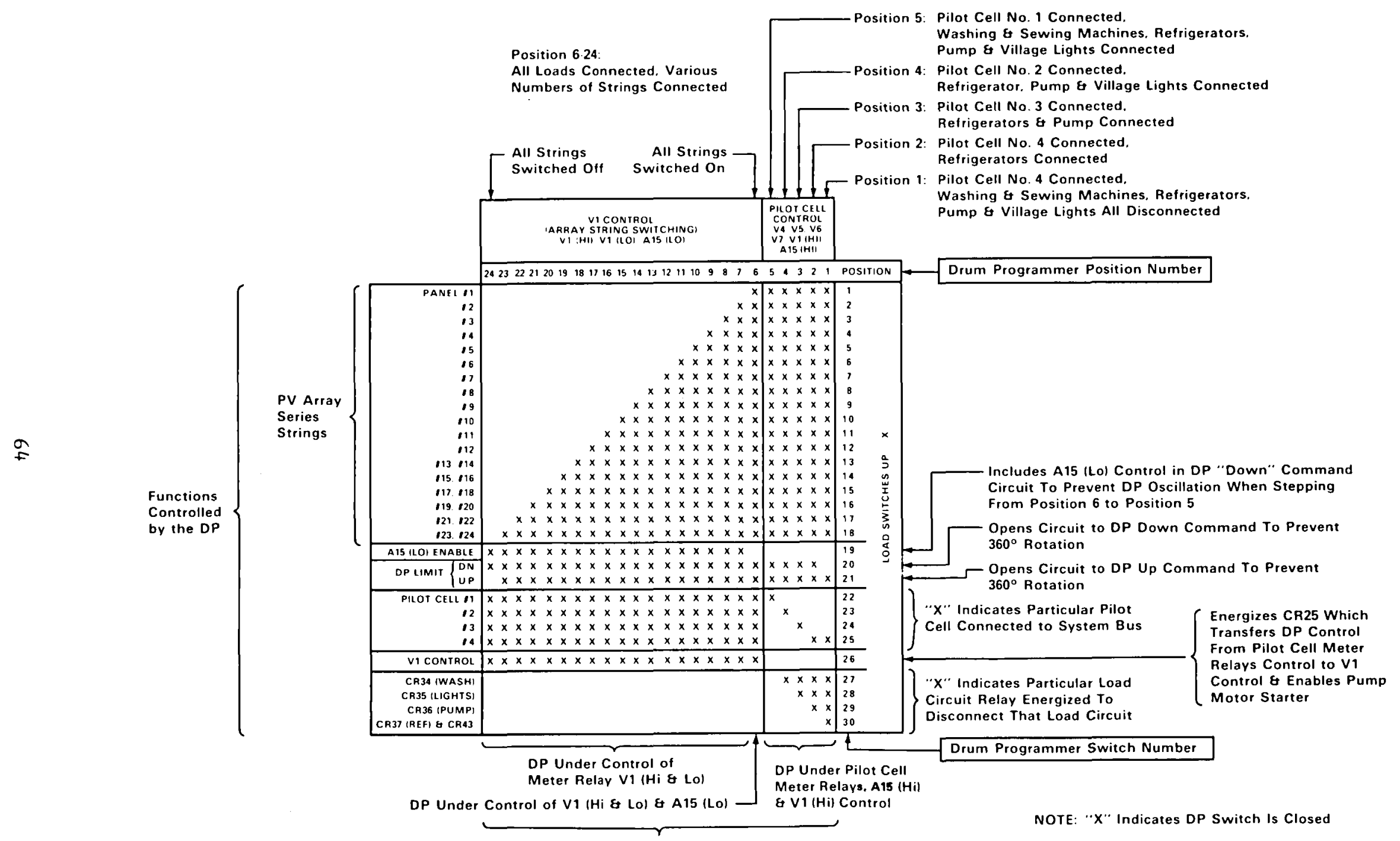

Elements Controlling the DP

Figure 26. Drum Programmer (DP) Schedule 


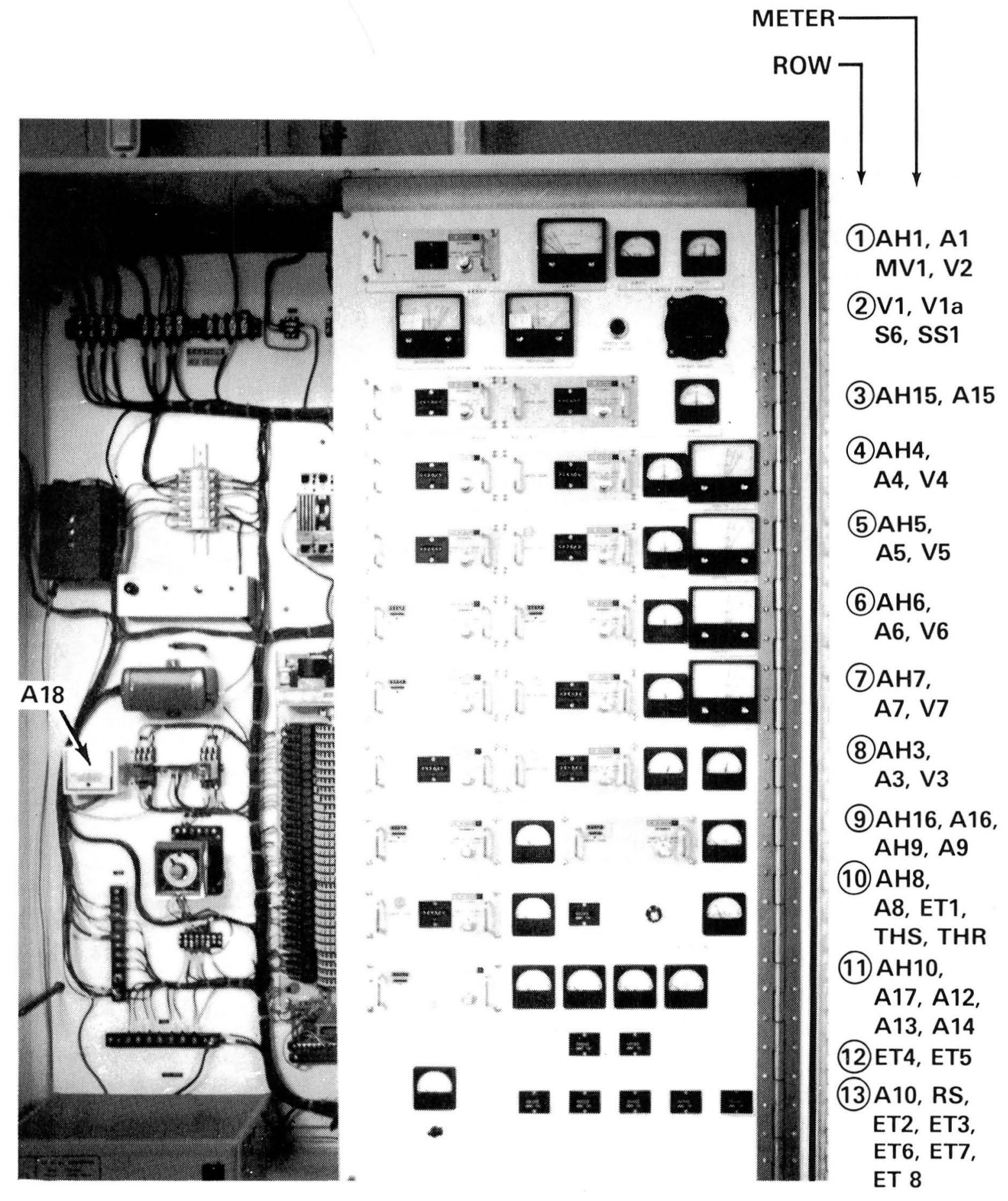

Figure 27. Instrument Panel Layout 
Table 10. Panel Meter Instrumentation

\begin{tabular}{|c|c|c|c|c|c|}
\hline LOCATION & SUBJECT & METER TYPE & LABEL & MEANING & $\begin{array}{l}\text { METER } \\
\text { RANGE }\end{array}$ \\
\hline \multicolumn{6}{|l|}{$\begin{array}{l}\text { PCCIA } \\
\text { Instrument } \\
\text { Panel }\end{array}$} \\
\hline \multirow[t]{4}{*}{ Row 1} & Array Total & Amp-hours & $\mathrm{AH} 1$ & $\begin{array}{l}\text { Accumulated current } \\
\text { from array }\end{array}$ & $0-9999.99$ and recycle \\
\hline & Array Total & Amps & A1 & Current from the array & $0-50$ amps \\
\hline & Array String & Amps & MV1 & Indiv. string current & 0.1 .5 amps \\
\hline & Array String & Volts & V2 & Indiv. string volts & 0.200 volts \\
\hline \multirow[t]{2}{*}{ Row 2} & $\begin{array}{l}\text { System } \\
\text { volts }\end{array}$ & Regulation & $v_{1}$ & $\begin{array}{l}\text { Controls drum pro. } \\
\text { grammer to maintain } \\
\text { proper voltage }\end{array}$ & $\begin{array}{l}90-140 \text { volts with } \\
\text { limits set at } \\
125 \text { and } 130\end{array}$ \\
\hline & & Protection & V1a & $\begin{array}{l}\text { Automatic shut off if } \\
\text { voltage reaches } \\
\text { extreme limits }\end{array}$ & $\begin{array}{l}90-140 \text { volts with } \\
\text { limits set at } \\
100 \text { and } 138\end{array}$ \\
\hline \multirow[t]{3}{*}{ Row 3} & Main Battery & Charge Amp-hours & $\mathrm{AH} 15$ & $\begin{array}{l}\text { Accumulated battery } \\
\text { charge current }\end{array}$ & $0-9999.99$ and recycle \\
\hline & & Discharge Amp-hours & $\mathrm{AH} 15$ & $\begin{array}{l}\text { Discharge current } \\
\text { discharged from miti. } \\
\text { battery }\end{array}$ & 0-9999.99 and recycle \\
\hline & & Amps & A15 & $\begin{array}{l}\text { Current to or from the } \\
\text { Main Battery }\end{array}$ & \pm 50 amps \\
\hline \multirow[t]{4}{*}{ Rows 4-7 } & Pilot Cells & Charge Amp-hours & $\mathrm{AH} 4.7$ & $\begin{array}{l}\text { Pilot Cell accumulated } \\
\text { charge current }\end{array}$ & 0-9999.99 and recycle \\
\hline & & Discharge Amp-hours & AH4.7 & $\begin{array}{l}\text { Pilot Cell accumulated } \\
\text { discharge current }\end{array}$ & 0-9999.99 and recycle \\
\hline & & Amps & A4-7 & $\begin{array}{l}\text { Current to or from } \\
\text { Pilot }\end{array}$ & $\begin{array}{l}\text { Pilot Cell } \sharp 1 \pm 50 \text { amps } \\
\text { Pilot Cell } \sharp 2 \div 50 \text { amps } \\
\text { Pilot Cell } \sharp 3 \pm 50 \text { amps } \\
\text { Pilot Cell } \# 4 \pm 50 \text { amps }\end{array}$ \\
\hline & & Volts & V4-7 & Pilot Cell voltage & 0.3 volts \\
\hline \multirow[t]{4}{*}{ Row 8} & $\begin{array}{l}\text { Instrument } \\
\text { and Control } \\
(I \& C)\end{array}$ & Charge Amp-hours & $\mathrm{AH} 3$ & $\begin{array}{l}\text { I\& } \mathrm{C} \text { Battery accumu- } \\
\text { lated charge }\end{array}$ & 0-9999.99 and recycle \\
\hline & & Discharge Amp-hours & $\mathrm{AH} 3$ & $\begin{array}{l}\text { I\&C Battery accumu- } \\
\text { lated discharge }\end{array}$ & 0.9999 .99 and recycle \\
\hline & & Amps & $A 3$ & $\begin{array}{l}\text { Current to or from the } \\
\text { IGC Battery }\end{array}$ & \pm 30 amps \\
\hline & & Volts & v3 & Battery voltage & $0-20$ volts \\
\hline
\end{tabular}


Table 10. Panel Meter Instrumentation (continued)

\begin{tabular}{|c|c|c|c|c|c|}
\hline LOCATION & SUBJECT & METER TYPE & LABEL & MEANING & $\begin{array}{l}\text { METER } \\
\text { RANGE }\end{array}$ \\
\hline \multirow[t]{4}{*}{ Row 9} & $\begin{array}{l}\text { Instrument } \\
\text { and Control } \\
\text { Load }\end{array}$ & Amp-hours & AH16 & $\begin{array}{l}\text { Accumulated current } \\
\text { used by instruments } \\
\text { and controls }\end{array}$ & 0.9999 .99 and recycle \\
\hline & & Amps & A16 & $\begin{array}{l}\text { Current to instru- } \\
\text { ments and controls }\end{array}$ & 0.10 amps \\
\hline & $\begin{array}{l}\text { Lights in the } \\
\text { village } \\
\text { homes, } \\
\text { church, Feast } \\
\text { House, EEB }\end{array}$ & Amp-hours & $\mathrm{AH} 9$ & $\begin{array}{l}\text { Accumulated current } \\
\text { used by lights }\end{array}$ & 0.9999 .99 and recycle \\
\hline & & Amps & A9 & Current to lights & 0.10 amps \\
\hline \multirow[t]{5}{*}{ Row 10} & Pump load & Amp-hours & $\mathrm{AH} 8$ & $\begin{array}{l}\text { Accumulated current } \\
\text { used by pump }\end{array}$ & 0-9999.99 and recycle \\
\hline & & Amps & A8 & Current to pump & $0-25$ amps \\
\hline & & Run Time (hours) & ET1 & $\begin{array}{l}\text { Total time pump has } \\
\text { run }\end{array}$ & 0.9999 .99 and recycle \\
\hline & Temperature & $\begin{array}{l}\text { Rotary selector and } \\
\text { temperature readout }\end{array}$ & $\begin{array}{l}\text { THS \& } \\
\text { THR }\end{array}$ & $\begin{array}{l}\text { Temperature in } \\
\text { degrees Fahrenheit: }\end{array}$ & \\
\hline & & & & $\begin{array}{l}\text { - Solar module temp. } \\
\text { - Refrigerator and } \\
\text { freezer for } 1 \text { unit } \\
\text { - Pump motor } \\
\text { - } 1 \text { cell of the main } \\
\text { battery } \\
\text { - Outside air temp. }\end{array}$ & $0-200^{\circ} \mathrm{F}$ \\
\hline \multirow[t]{5}{*}{ Row 11} & $\begin{array}{l}\text { Total Loads } \\
\text { in DSB }\end{array}$ & Amp-hours & $\mathrm{AH} 10$ & $\begin{array}{l}\text { Accumulated current } \\
\text { used by all loads in } \\
\text { the DSB. }\end{array}$ & 0.9999 .99 and recycle \\
\hline & & Amps Total & A17 & Total DSB current & 0.25 amps \\
\hline & $\begin{array}{l}\text { Washing } \\
\text { Mach. }\end{array}$ & Amps & $A 12$ & $\begin{array}{l}\text { Current to the wash- } \\
\text { ing machine }\end{array}$ & $0-5$ amps \\
\hline & $\begin{array}{l}\text { Sewing } \\
\text { Mach. }\end{array}$ & Amps & A13 & $\begin{array}{l}\text { Current to sewing } \\
\text { machine }\end{array}$ & $0-1$ amps \\
\hline & Lights & Amps & A14 & DSB light current & 0-1 amps \\
\hline \multirow[t]{2}{*}{ Row 12} & $\begin{array}{l}\text { Washing } \\
\text { mach. }\end{array}$ & Run Time (hours) & ET4 & $\begin{array}{l}\text { Run time of washing } \\
\text { mach. }\end{array}$ & 0.9999 .99 and recycle \\
\hline & $\begin{array}{l}\text { Sewing } \\
\text { mach. }\end{array}$ & Run Time & ET5 & $\begin{array}{l}\text { Run time of sewing } \\
\text { mach. }\end{array}$ & 0-9999.99 and recycle \\
\hline Row 13 & $\begin{array}{l}\text { Compressor } \\
\text { load }\end{array}$ & $\begin{array}{l}\text { Amps \& Rotary } \\
\text { selector }\end{array}$ & $\begin{array}{l}\text { A10. } \\
\text { RS }\end{array}$ & $\begin{array}{l}\text { Individual \& total } \\
\text { compressor current }\end{array}$ & 0.10 amps \\
\hline
\end{tabular}


Table 10. Panel Meter Instrumentation (continued)

\begin{tabular}{|c|c|c|c|c|c|}
\hline LOCATION & SUBJECT & METER TYPE & LABEL & MEANING & $\begin{array}{l}\text { METER } \\
\text { RANGE }\end{array}$ \\
\hline & $\begin{array}{l}\text { Compressor } \\
\text { run time }\end{array}$ & Run time (hours) & $\begin{array}{l}\text { ET2. } \\
\text { ET3, } \\
\text { ET6, } \\
\text { ET7, } \\
\text { ET8 }\end{array}$ & $\begin{array}{l}\text { Run time of refrig. } \\
\text { erator }\end{array}$ & 0.9999 .99 and recycle \\
\hline \multirow{2}{*}{$\begin{array}{l}\text { Inside } \\
\text { Panel of } \\
\text { PCCIA }\end{array}$} & $\begin{array}{l}\text { Converter } \\
\text { Output }\end{array}$ & Amps & A18 & $\begin{array}{l}\text { Current output of } \\
120 \mathrm{~V} \text { converter }\end{array}$ & 0.15 amps \\
\hline & $\begin{array}{l}\text { Drum/ } \\
\text { Programmer/ } \\
\text { Position }\end{array}$ & & & $\begin{array}{l}\text { Number of strings } \\
\text { turned on or condition } \\
\text { of load shedding }\end{array}$ & STEP $1 \longrightarrow 24$ \\
\hline $\begin{array}{l}\text { Water } \\
\text { Pump }\end{array}$ & Water meter & Water (gal) & & $\begin{array}{l}\text { Amount of water } \\
\text { pumped from the well }\end{array}$ & 99999.99 \\
\hline \multicolumn{6}{|l|}{ DSB } \\
\hline \multirow[t]{3}{*}{$\begin{array}{l}\text { Water Stor- } \\
\text { age Tank }\end{array}$} & Water & Target & & $\begin{array}{l}\text { Amount of water } \\
\text { stored in the tank }\end{array}$ & Estimate $1 / 2,1 / 4$, etc. \\
\hline & & Water (gal) & & & \\
\hline & & & & $\begin{array}{l}\text { Amount of water } \\
\text { used in the DSB }\end{array}$ & 99999.99 \\
\hline
\end{tabular}




\section{SAFETY}

Throughout the design and installation of this system, safety for user, operational and maintenance, and installation personnel was of utmost concern. All areas of access needed for operation or maintenance are locked. Only authorized, properly trained people are allowed into the array field, the water pump area, the EEB, and the panel No. 2 in the DSB. All loads are hard wired to wall switches thus preventing unauthorized access to the $120-\mathrm{V}$ (d.c.) lines. Visual and audio signals are provided to alert the operator to abnormal conditional. The battery room is vented and separate from the control room in the EEB and is provided with an emergency eye flush and shower facility in case of contact with battery acid. The array is located apart from the normal village activitiy areas to reduce the probability of damage to the PV cells as well as to reduce the accumulation of dirt and other airborne material.

An emergency OFF button is also provided in the EEB to disconnect the array and batteries from all loads and controls in the PCCIA. This condition does not automatically reset and must be manually reset to restore power to the system.

Two circuit breakers protect the power supplied to the DSB from the EEB. A circuit breaker, CB8, in the DSB protects the loads and users from fault conditions. A circuit breaker, $\mathrm{CB} 6$, in the EEB, protects the transmission lines from the EEB to the DSB. 


\section{COMMENTS ON SYSTEM OPERATION}

The Schuchuli system has been operating satisfactorily since its dedication in December 1978. Data from system operations are being reduced and anlayzed and will be reported separately. There were some minor design changes made after the system became operational, and these have been included in the text. Two of these design changes are worth discussing further. One was to correct a manufacturer shortcoming in the optical motor relays, and the other was to correct a problem in the load management control relay logic.

The problem with the optical meter relays was premature burnout of the meter relay lamp due to higher than design operating voltage. When a motor relay burns out, all contacts in the relay transfer causing various system perturbations depending upon which meter relay is affected. Premature lamp burnout occurred because the meter relays were designed for 12volt operation, but not for 12 -volt battery operation, i.e., voltages up to 14 volts. To obtain the 5 volts necessary to operate the lamp, the manufacturer merely inserted an appropriate dropping resistor. The nominal 12-volt I/C bus normally floats at 13.6 -volts thus increasing lamp voltage and substantially reducing lamp life. LeRC engineers subsequently designed and installed lamp voltage regulators in all meter relays which hold lamp voltage at 5 volts independent of source voltage. The manufacturer was alerted to this design problem.

The nature of and fix for the load mangement control logic problem is described in paragraph 6 on page 58. While the system was under pilot cell control, high system voltage caused $\mathrm{CBl}$ to be tripped. Although the alarm light was on (the audio alarm was subsequently installed), the condition went unnoticed until the battery became 60 percent discharged. At about this same time (December 1979), the contacts in the thermostat switch of the freeze protection heater for the solar hot water heater welded closed imposing a 300-walt continuous load on the system. Before the condition was noted, the battery had intermittently reached greater than 70 percent DOD. Although the control logic and heater failure were untimely problems, together they forced the exercise of the load management system which, in all other respects, operated properly.

\section{CONCLUDING REMARKS}

The Schuchuli Village Project was designed to show that PV power systems can provide electricity for essential village needs in remote locations. Over $2 \frac{1}{2}$ years of operation and a 98.6 percent online record has proved the validity of the concept of village PV power systems and the design of this system. The village has been visited by well over 200 official visitors representing 55 foreign countries. In testimony to the validity of the project, there are now village power systems being designed for villages in several countries. 
APPENDIX A

\section{DESIGN DRA WINGS}

NASA LeRC DRAWING NOs. CF 56375 THROUGH CF 56382 


\section{PHOTO VOLTAIC VILLAGE POWER SYSTEM SCHUCHULI ARIZONA}

D. O.E. - N.A.S.A.

LEWIS RESEARCH CENTER TESTS AND APPLICATION PROJECT

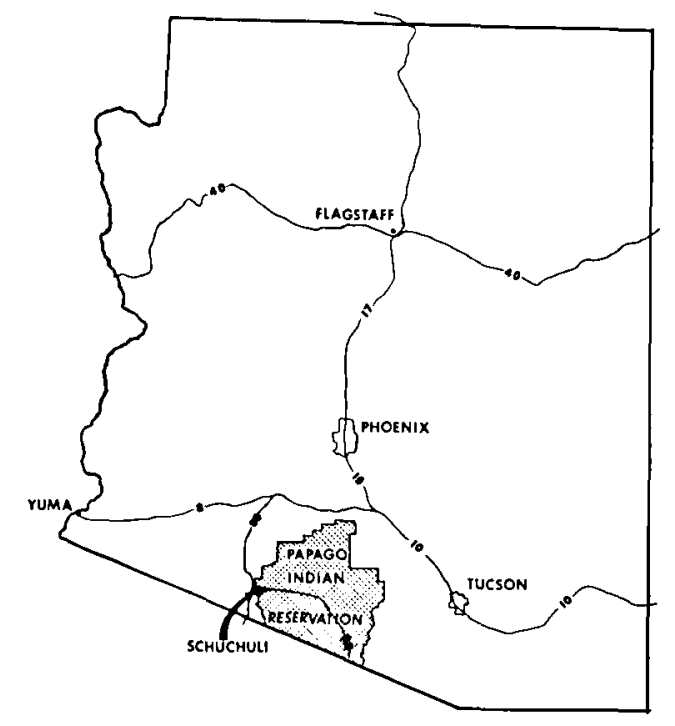

INDEX OF DRAWINGS

CF56375 TITLE SHEET

CF56376 SITE PLAN, ARRAY FIELD PLAN, FENCE

CF56377 ELECTRICAL EQUIPMENT BUILDING-

CF56378 TYPICAL SOLAR PANEL AND DETALLS

CF56379 ELECTRICAL PLANS AND DETAILS

CF56380 ONE LINE DIAGRAM AND ARRAY DETAILS 



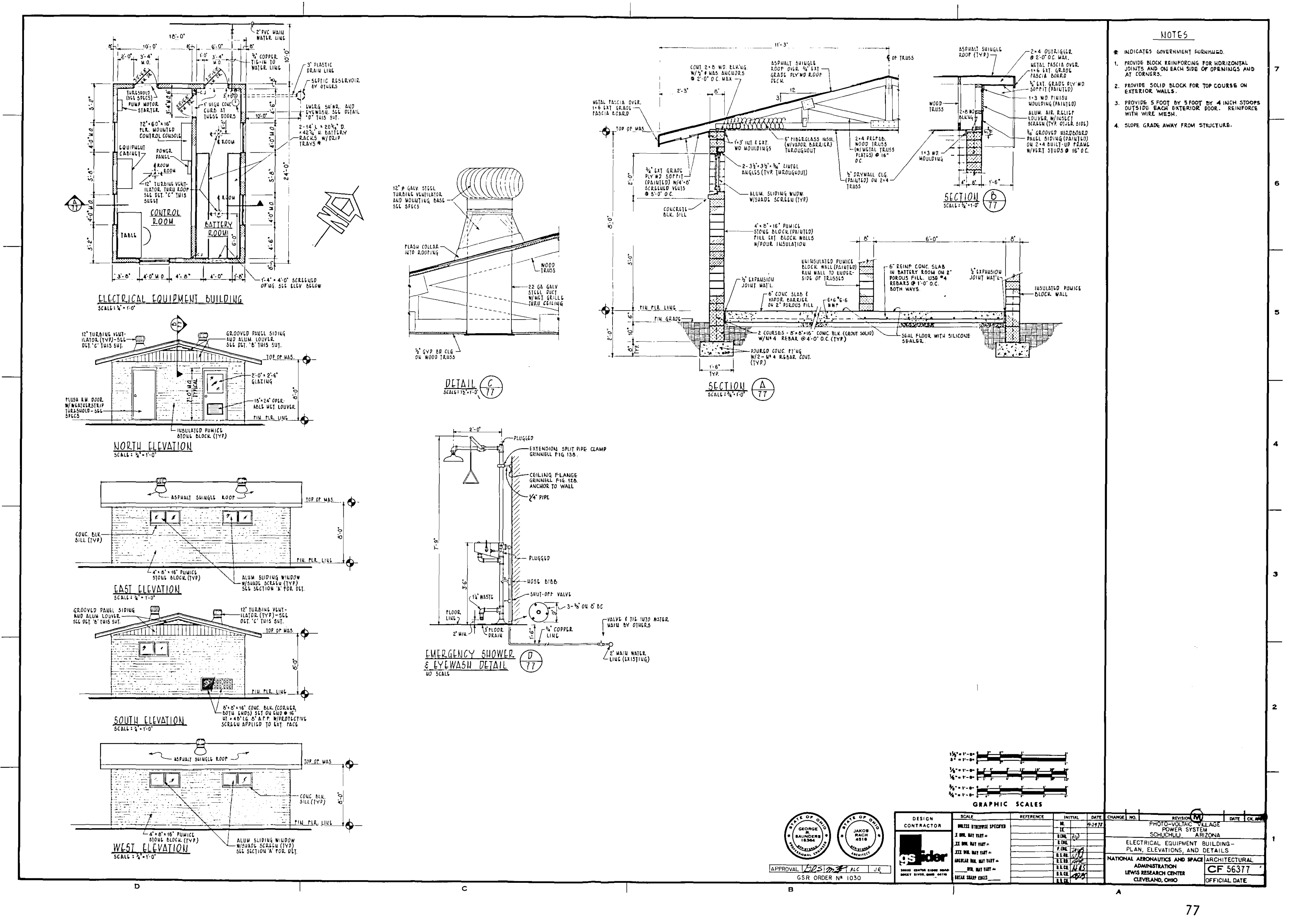




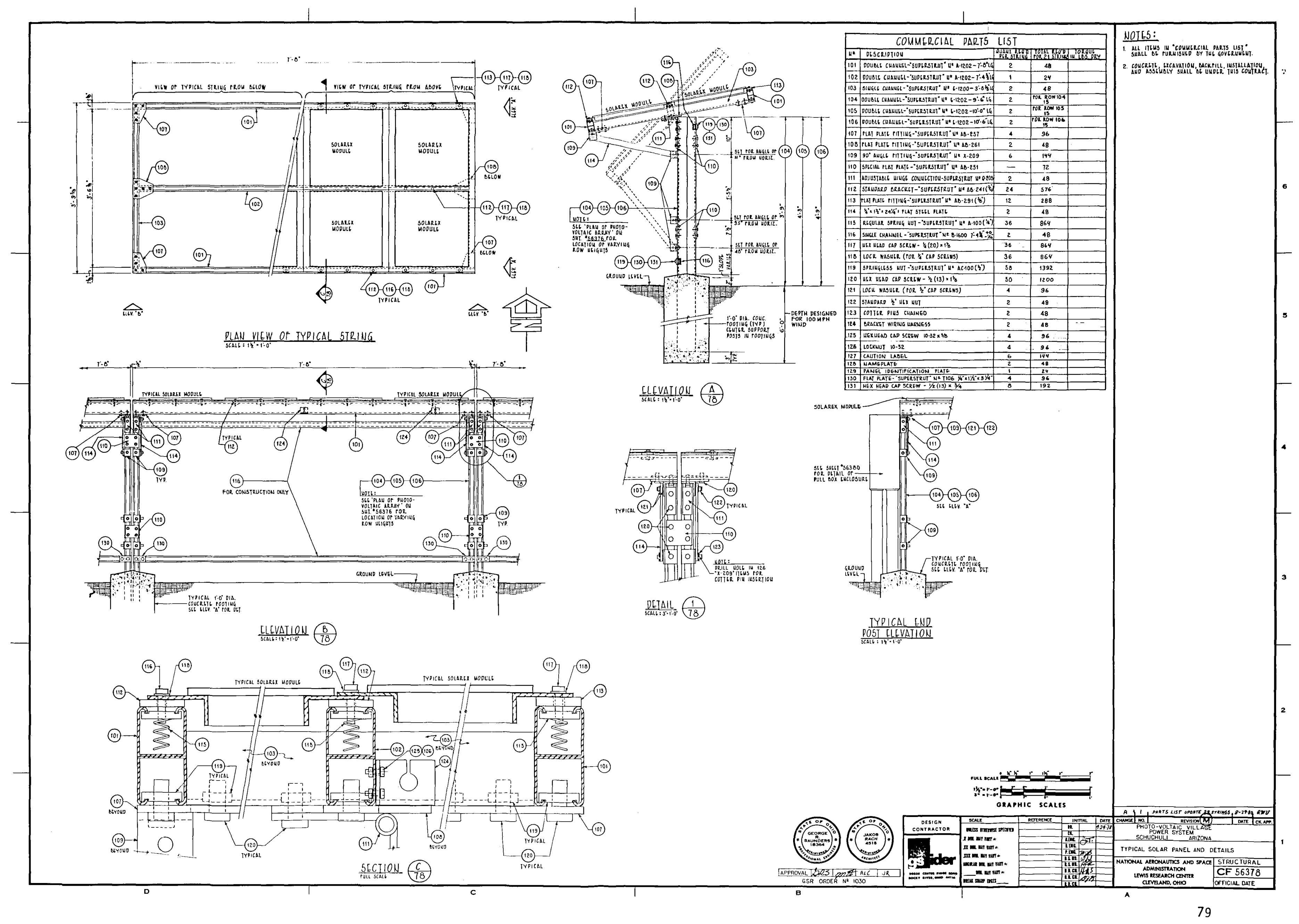





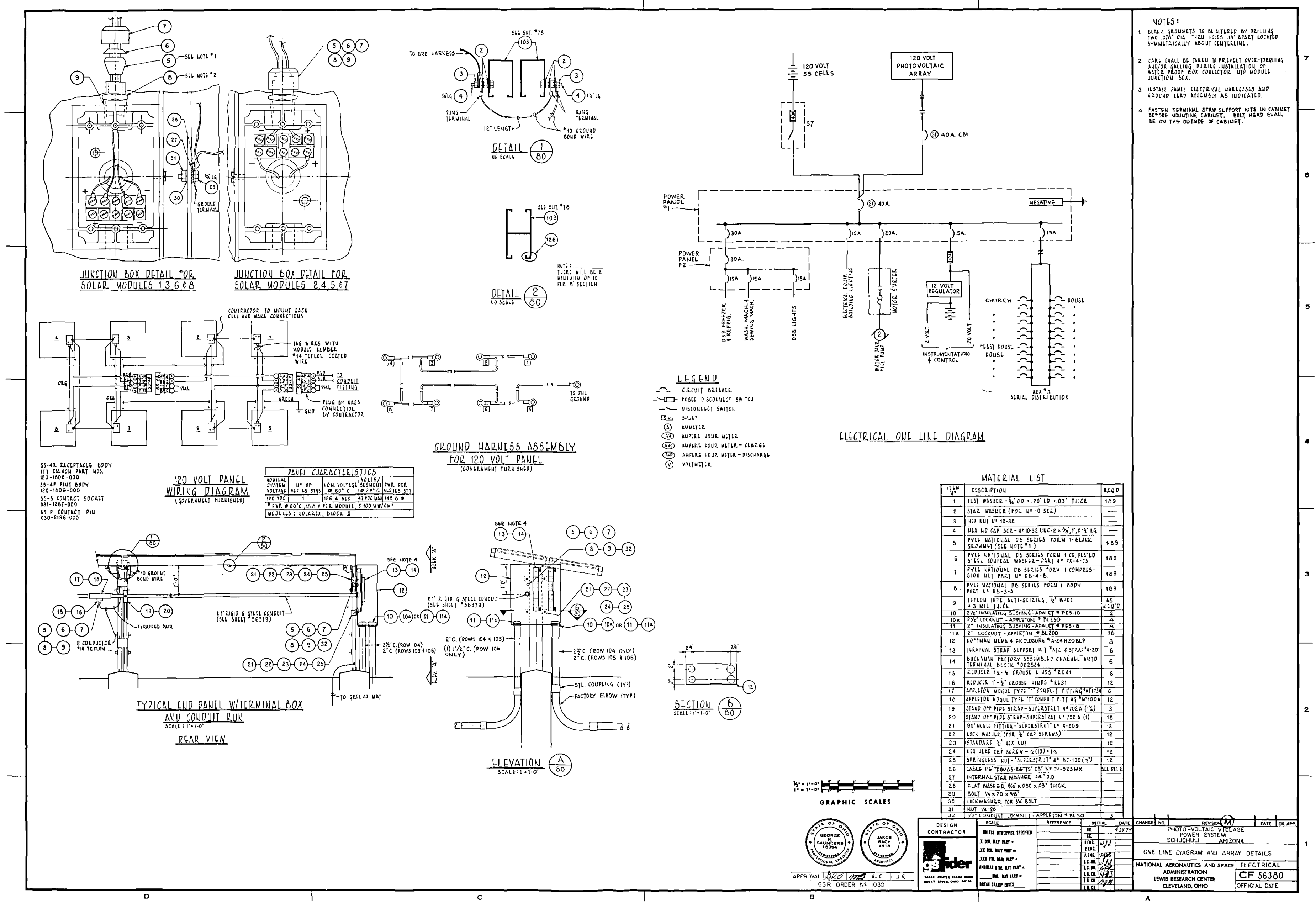





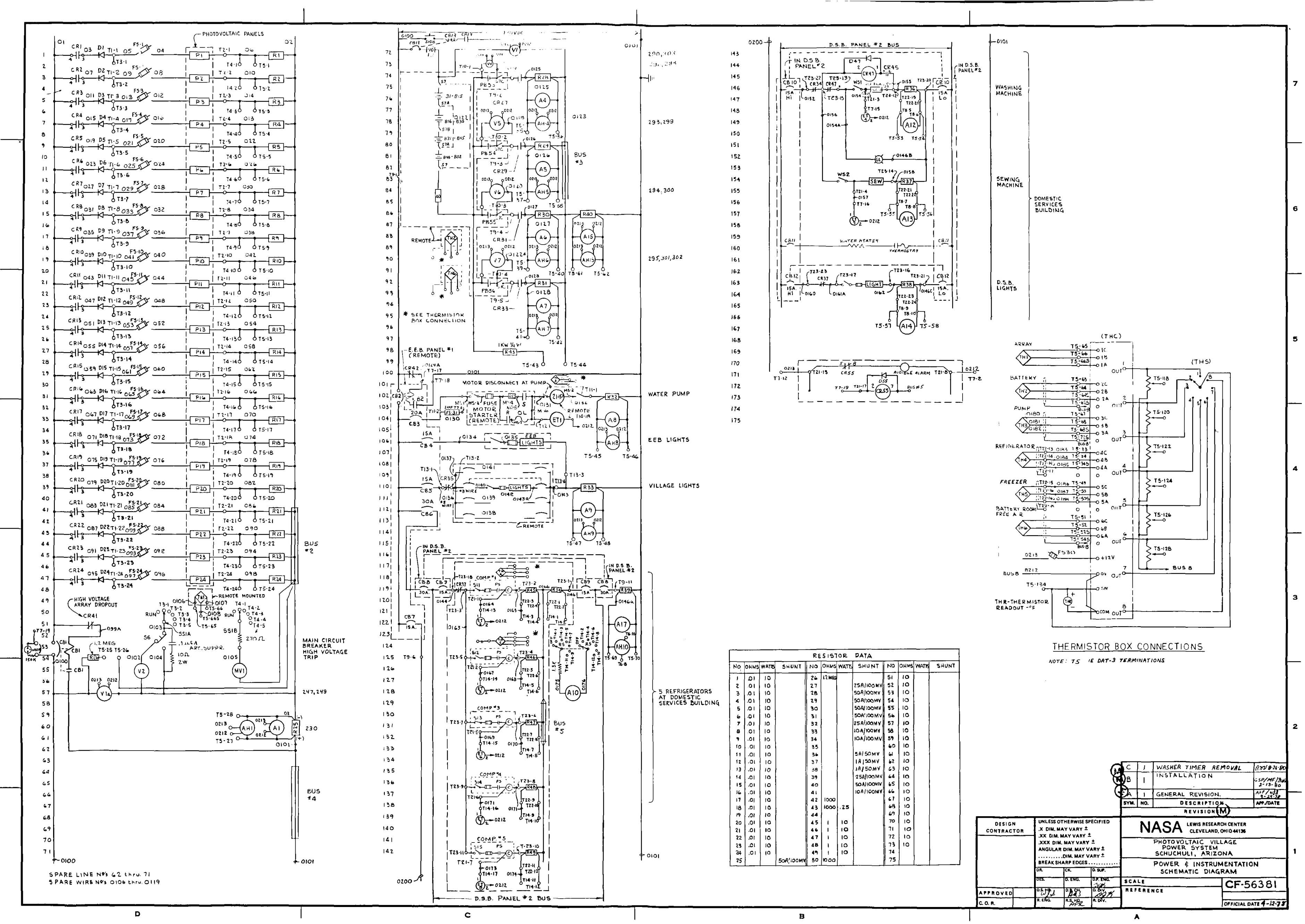

D 


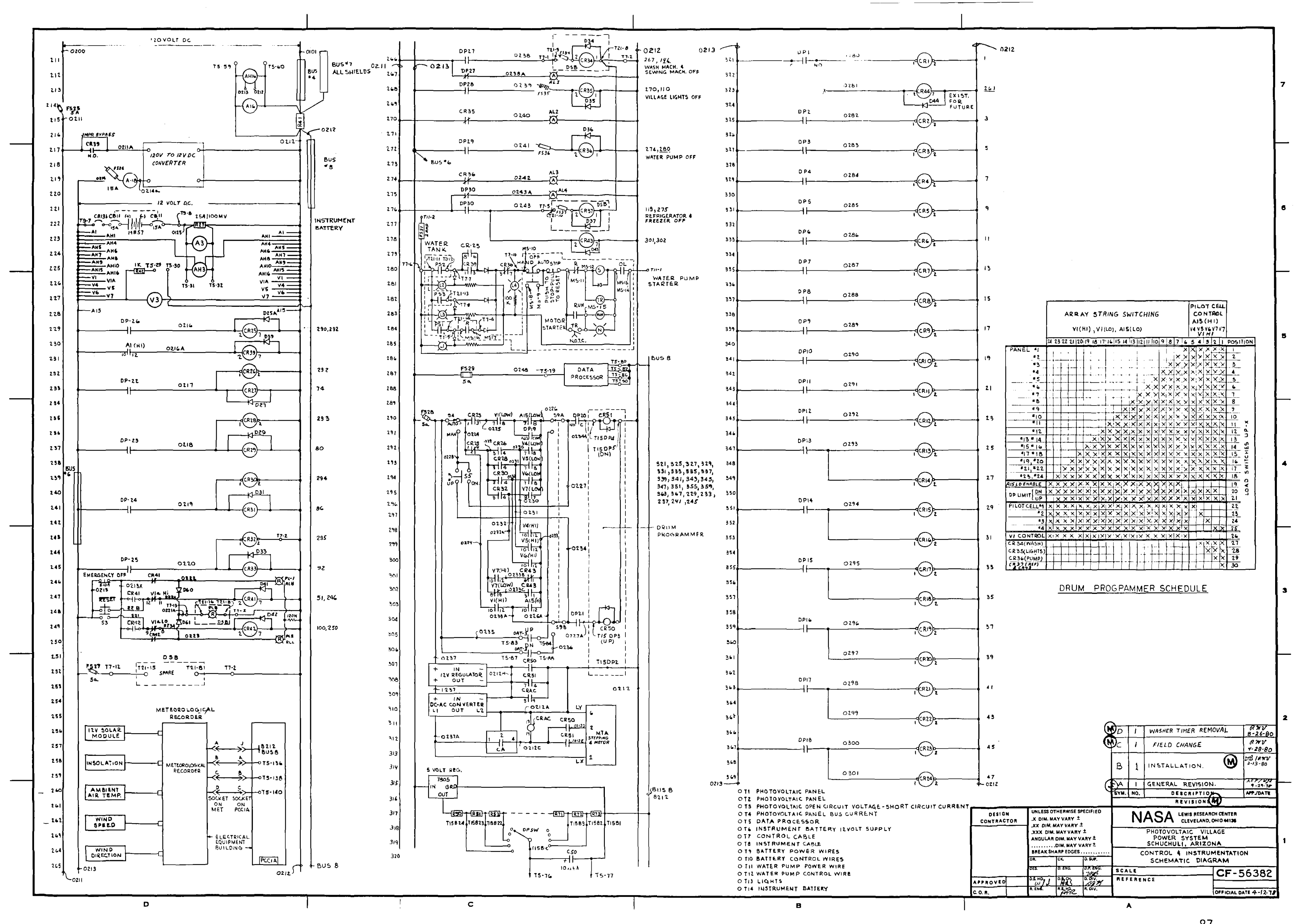





\section{APPENDIX B}

\section{MANUFACTURERS AND EQUIPMENT}

(This list of manufacturers and equipment is provided for information purposes only and does not imply endorsement by the NASA-Lewis Research Center or the U.S. Department of Energy.)

\section{Equipment \\ POWER SYSTEMS}

Solar Cell Modules

$9200 J$

LCPSA -19

KCPSA -15

DCPSA -15

Array PV Panel and Panel

Support Structural

Material

Storage Battery Cells

(lead-calcium)
Model

Vendor
Solarex Corporation

1335 Piccard Drive

Rockville, MD 20850

Attn: Joseph Lindmayer

(202) 948-0202

Super Strut

802 Eisenhower Drive, North

Goshen, IN 46526

(219) 533-0335

C\&D Batteries Division

Eltra Company

3043 Walton Road

Plymouth Meeting, PA 19462

Attn: Mr. Henry Jensen

(215) 828-9000

\section{LOADS}

Refrigeration

\section{$4.5 \mathrm{ft}^{3}$ with compressors}

DC Inverter Ballasts

for Fluorescent

Lights

Sewing Machine

(Universal Motor)

$115 \mathrm{RS} 20 \mathrm{BEB} 2$
Magna-Kold, Inc. 1790 Monrovia Avenue Costa Mesa, CA 92627 Attn: Mr. Ralph Baker (714) 631-2555

The Bodine Company 236 Mt. Pleasant Road Colliersville, TN 38017 Attn: Mr. Dick Bodone (901) 853-7211

White Sewing Machine Co. 11750 Berea Road Cleveland, OH 44111

Attn: Mr. Joseph Arendash (216) $252-3300$ 


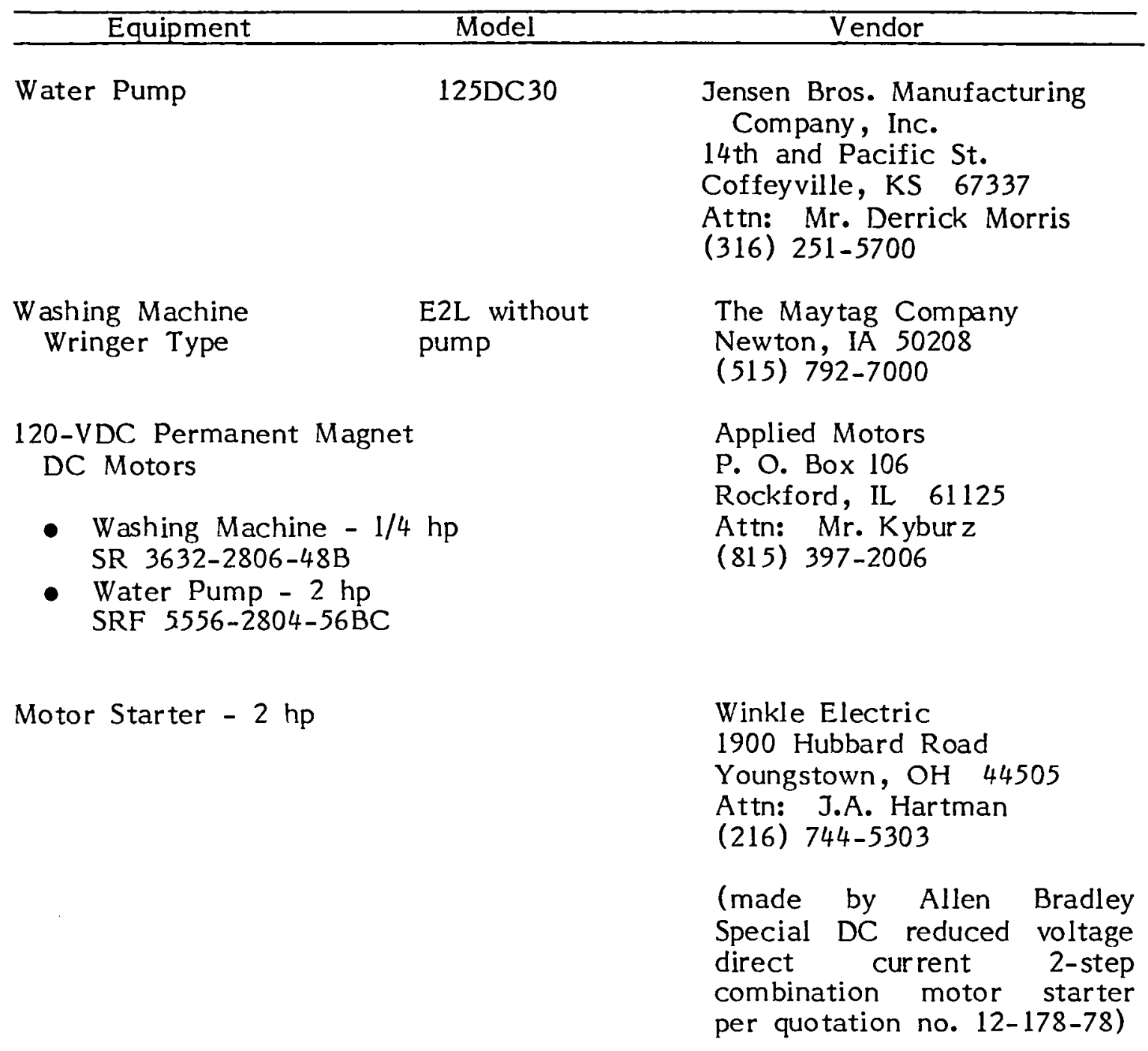

INSTRUMENTATION \& CONTROL

Electronic Weather $\quad 100243$
Station

Climatronics Corp. 1324 Motor Parkway Hauppauge, NY 11787

Attn: R. Throop Bergh

(516) 234-2772

Datalogger DAT-3

Mars Data Systems 14666 Doolittle Drive San Leandro, Calif. 94577 Attn: Arthur A. Loya (415) 483-7902 


\begin{tabular}{|c|c|c|}
\hline Equipment & Model & Vendor \\
\hline $\begin{array}{l}\text { Programmable Drum } \\
\text { Relay (PDR) } \\
\text { PDR System }\end{array}$ & JDS 2343 & $\begin{array}{l}\text { Eagle Signal Division } \\
736 \text { Federal Street } \\
\text { Industrial Controls } \\
\text { Davenport, Iowa } 52803 \\
\text { Attn: Don Morris } \\
\text { (319) 326-8105 }\end{array}$ \\
\hline $\begin{array}{l}\text { 12V Regulator } \\
\text { PDR Subsystem }\end{array}$ & 1340 & $\begin{array}{l}\text { Wilmore Electronics Co. } \\
\text { Post Office Box } 1329 \\
\text { Hillsborough, N.C. } 27278 \\
\text { Attn: Chris Ely } \\
\text { (919) } 732-9351\end{array}$ \\
\hline $\begin{array}{l}\text { DC to AC Inverter } \\
\text { PDR Subsystem } \\
12 \mathrm{~V} \text { DC to } 120 \mathrm{~V} A C\end{array}$ & TROJAN $50-120$ & $\begin{array}{l}\text { Terado Corp. } \\
1068 \text { Raymond Ave. } \\
\text { St. Paul, MN 55108 } \\
\text { Attn: Fred Munson } \\
(612) 646-2868\end{array}$ \\
\hline $\begin{array}{l}\text { AC Timer } \\
\text { PDR Subsystem }\end{array}$ & CA2222S3A60310 & $\begin{array}{l}\text { Eagle Signal Division } \\
736 \text { Federal St. } \\
\text { Industrial Controls } \\
\text { Davenport, Iowa } 52803 \\
\text { Attn: Don Morris } \\
\text { (319) 326-8105 }\end{array}$ \\
\hline $\begin{array}{l}\text { Thermistor Readout } \\
\text { System }\end{array}$ & $16508 \times 8$ & $\begin{array}{l}\text { Yellow Springs Instrument } \\
\text { Company } \\
\text { Box } 279 \\
\text { Yellow Springs, Ohio } 45387 \\
\text { Attn: Phil Chitty } \\
\text { (513) 767-7241 }\end{array}$ \\
\hline Elapsed Time Indicator & LTH 15.10 & $\begin{array}{l}\text { Kessler \& Ellis Products } \\
\text { Dept EM } \\
120 \text { 1st Ave. } \\
\text { Atlantic, Highlands, N.J. } \\
\text { 07716 } \\
\text { Attn: Ray Pocza } \\
\text { (216) } 247-3295\end{array}$ \\
\hline $\begin{array}{l}\text { DC Convertor } \\
\text { ( } 120 \mathrm{~V} \text { DC to } 12 \mathrm{~V} \mathrm{DC}) \\
\text { Instrument Battery } \\
\text { Regulator }\end{array}$ & 1295 & $\begin{array}{l}\text { Wilmore Electronics Co. } \\
\text { Post Office Box 1329 } \\
\text { Hillsborough, NC } 27278 \\
\text { Attn: Chris Ely } \\
\text { (919) 732-9351 }\end{array}$ \\
\hline
\end{tabular}




\begin{tabular}{cll}
\hline Equipment & Model & \multicolumn{1}{c}{ Vendor } \\
\hline Ampere Hour Meter & 1002 & Cur tis Instruments \\
& & 200 Kisco Ave. \\
& Mt. Kisco, NY 10549 \\
& Attn: Rhoda McDonald \\
& $(914) 666-2971$ \\
CoMPAK I-503K & LFE Corp. \\
Metical Controller & 1601 Trapelo Rd. \\
& Waltham, Mass. 02154 \\
& Attn: Ray Pocza \\
& (216) 247-3295
\end{tabular}





\begin{tabular}{|c|c|c|c|c|}
\hline $\begin{array}{l}\text { 1. Report No. } \\
\text { NASA TM-82650 }\end{array}$ & \multicolumn{2}{|c|}{ 2. Government Accession No. } & \multicolumn{2}{|c|}{ 3. Recipient's Catalog No. } \\
\hline \multirow{2}{*}{\multicolumn{3}{|c|}{$\begin{array}{l}\text { 4. Title and Subtitle } \\
\text { DESIGN DESCRIPTION OF THE SCHUCHULI VILLAGE } \\
\text { PHOTOVOLTAIC POWER SYSTEM }\end{array}$}} & \multicolumn{2}{|l|}{$\begin{array}{l}\text { 5. Report Date } \\
\text { May } 1981\end{array}$} \\
\hline & & & \multicolumn{2}{|c|}{$\begin{array}{l}\text { 6. Performing Organization Code } \\
776-52-41\end{array}$} \\
\hline \multirow{2}{*}{\multicolumn{3}{|c|}{$\begin{array}{l}\text { 7. Author(s) } \\
\text { Anthony F. Ratajczak, Richard W. Vasicek, and } \\
\text { Richard DeLombard }\end{array}$}} & \multicolumn{2}{|c|}{$\begin{array}{l}\text { 8. Performing Organization Report No. } \\
\text { E-908 }\end{array}$} \\
\hline & & & \multicolumn{2}{|l|}{ 10. Work Unit No. } \\
\hline \multirow{2}{*}{\multicolumn{3}{|c|}{$\begin{array}{l}\text { Lewis Research Center } \\
\text { Cleveland, Ohio } 44135\end{array}$}} & \multicolumn{2}{|c|}{ 11. Contract or Grant No. } \\
\hline & & & \multicolumn{2}{|c|}{$\begin{array}{l}\text { 13. Type of Report and Period Covered } \\
\text { Technical Memorandum }\end{array}$} \\
\hline \multicolumn{3}{|c|}{$\begin{array}{l}\text { 12. Sponsoring Agency Name and Address } \\
\text { U.S. Department of Energy } \\
\text { Division of Solar Thermal Energy Systems } \\
\text { Washington, D.C. } 20545\end{array}$} & \multicolumn{2}{|c|}{$\begin{array}{l}\text { 14. Sponsoring Agency Code Report Na } \\
\text { DOE/NASA/20485-10 }\end{array}$} \\
\hline \multicolumn{5}{|c|}{$\begin{array}{l}\text { 15. Supplementary Notes } \\
\text { Final report. Prepared under Interagency Agreement DE-AI01-79ET20485. }\end{array}$} \\
\hline \multicolumn{5}{|c|}{$\begin{array}{l}\text { 16. Abstract } \\
\text { This report describes the engineering design of a stand-alone photovoltaic (PV) power system for the } \\
\text { village of Schuchuli (Gunsight), Arizona, on the Papago Indian Reservation, This experimental solar power } \\
\text { system project was funded by the Department of Energy and implemented by the National Aeronautics and } \\
\text { Space Administration, Lewis Research Center, together with the United States Department of Health and } \\
\text { Human Services, Public Health Service, Indian Health Service, Office of Research and Development, Office } \\
\text { of Environmental Health, and the Papago Tribe of Arizona, The purpose of this experiment was to demon- } \\
\text { strate that a stand-alone photovoltaic power system could provide dependable power for basic human needs } \\
\text { in a remote village environment. The power system was designed as a limited energy, all 120-V (d. c.) } \\
\text { system to which loads cannot be arbitrarily added. The system consists of a 3. 5-kW (peak) PV array, } \\
\text { 2380 ampere-hours of battery storage, an Electrical Equipment Building, a 120-V (d, c.) electrical distri- } \\
\text { bution network, and equipment and automatic controls to provide control power for pumping water into an } \\
\text { existing water system; operating } 15 \text { refrigerators, a clothes washing machine, and a sewing machine in the } \\
\text { Domestic Services Building; and lights for each of the homes and communal buildings. In addition, a solar } \\
\text { hot water heater was provided to supply hot water for the washing machine and communal laundry. The } \\
\text { system employs automatic control systems which provide voltage control by limiting the number of PV } \\
\text { strings supplying power during system operation and battery charging, and load management for operating } \\
\text { high priority loads at the expense of low priority loads as the main battery becomes depleted. The } \\
\text { engineering design of this system is presented in this report and includes loads profiles and loads des- } \\
\text { criptions; an explanation of the PV array and battery sizing methodology; descriptions of the mechanical } \\
\text { designs; electrical designs and descriptions of the array, battery, controls, instrumentation and distribu- } \\
\text { tion system; and a discussion of safety features. The system was dedicated and began operation on } \\
\text { December 16, 1978. The operational history and data are not contained in this report. }\end{array}$} \\
\hline $\begin{array}{l}\text { 17. Key Words (Suggested by Author(s)) } \\
\text { Schuchuli Village Photovoltaic }\end{array}$ & Power System & $\begin{array}{l}\text { 18. Distribu } \\
\text { Uncla } \\
\text { STAF } \\
\text { DOE }\end{array}$ & $\begin{array}{l}\text { unlimited } \\
\text { y } 44 \\
\text { UC-63 }\end{array}$ & \\
\hline $\begin{array}{l}\text { 19. Security Classif. (of this report) } \\
\text { Unclassified }\end{array}$ & $\begin{array}{r}\text { 20. Security Classif. } \\
\text { Unc }\end{array}$ & $\begin{array}{l}\text { of this page) } \\
\text { assified }\end{array}$ & 21. No. of Pages & 22. Price" \\
\hline
\end{tabular}

${ }^{*}$ For sale by the National Technical Information Service, Springfield, Virginia 22161 
$$
\text { . }
$$ 
